Industry Stakeholder Recommendations for DOE's RD\&D for Increasing Energy Efficiency in Existing Homes

P. Plympton and L. Dagher National Renewable Energy Laboratory

B. Zwack

Sentech, Inc.
Technical Report NREL/TP-710-41705 June 2007

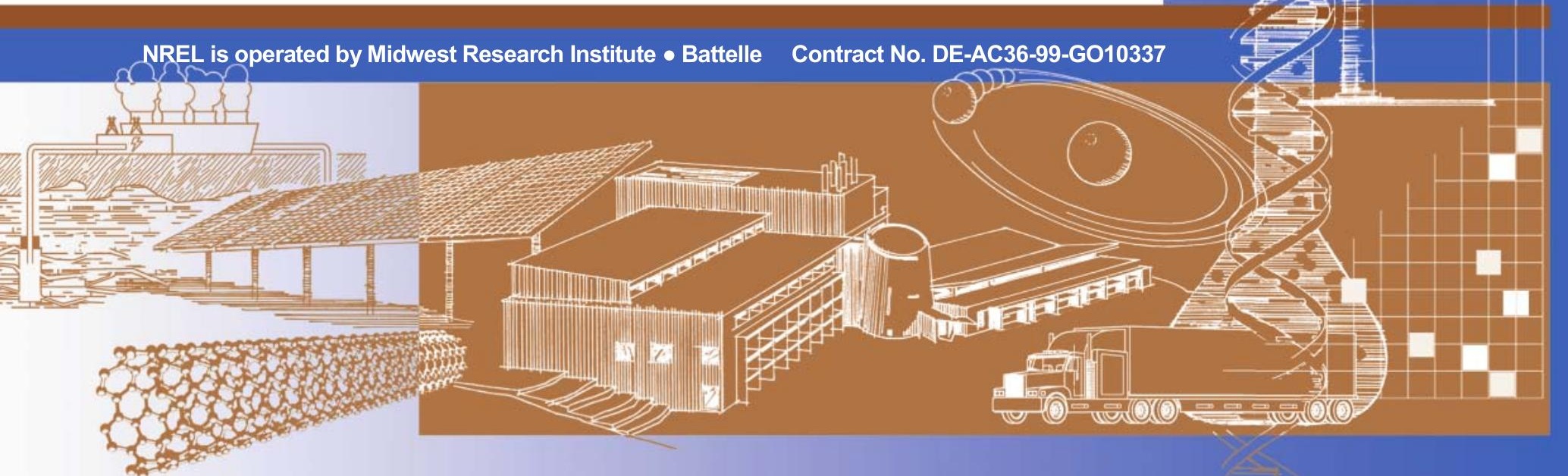




\section{Industry Stakeholder Recommendations for DOE's RD\&D for Increasing Energy Efficiency in Existing Homes}

Technical Report NREL/TP-710-41705 June 2007

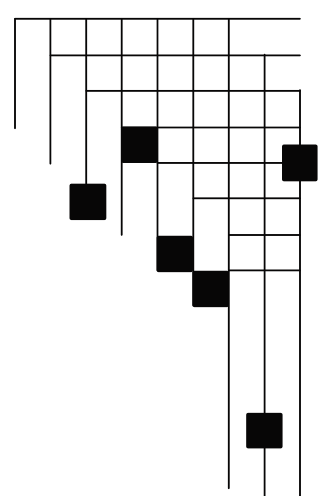

Prepared under Task No. BEES.0750 


\section{NOTICE}

This report was prepared as an account of work sponsored by an agency of the United States government. Neither the United States government nor any agency thereof, nor any of their employees, makes any warranty, express or implied, or assumes any legal liability or responsibility for the accuracy, completeness, or usefulness of any information, apparatus, product, or process disclosed, or represents that its use would not infringe privately owned rights. Reference herein to any specific commercial product, process, or service by trade name, trademark, manufacturer, or otherwise does not necessarily constitute or imply its endorsement, recommendation, or favoring by the United States government or any agency thereof. The views and opinions of authors expressed herein do not necessarily state or reflect those of the United States government or any agency thereof.

Available electronically at http://www.osti.gov/bridge

Available for a processing fee to U.S. Department of Energy and its contractors, in paper, from:

U.S. Department of Energy

Office of Scientific and Technical Information

P.O. Box 62

Oak Ridge, TN 37831-0062

phone: 865.576 .8401

fax: 865.576 .5728

email: mailto:reports@adonis.osti.gov

Available for sale to the public, in paper, from:

U.S. Department of Commerce

National Technical Information Service

5285 Port Royal Road

Springfield, VA 22161

phone: 800.553.6847

fax: 703.605.6900

email: orders@ntis.fedworld.gov

online ordering: http://www.ntis.gov/ordering.htm 


\section{Acknowledgments}

DOE wishes to thank all those who participated in the industry stakeholder feedback sessions held at the following conferences:

- The Remodeling Show, Oct. 2005, Baltimore, MD

- Environmental and Energy Building Association Conference, Oct. 2005, Colorado Springs, $\mathrm{CO}$

- RESNET Conference, Feb. 2006, San Antonio, TX

- Affordable Comfort Incorporated (ACI) Home Performance Conference, May 2006, Austin, TX.

The recommendations collected will enable DOE to more effectively target its future research and development of existing home technologies and best practices.

DOE thanks Patricia Plympton and Leila Dagher of the National Renewable Energy Laboratory and Bill Zwack of SENTECH, Inc. for planning and conducting the feedback sessions and preparing this report.

Also, DOE thanks Paul Norton of NREL for his technical review and suggestions for improving the document. In addition, DOE thanks Courtney Moriarta of Steven Winter Associates, Inc. for her efforts in preparing and coordinating research to enhance the effectiveness of this report. 


\section{Table of Contents}

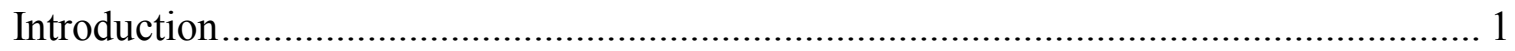

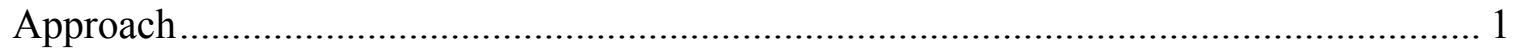

Feedback Session Design and Conference Selection................................................... 1

Feedback Interpretation and Categorization ................................................................. 2

Feedback Evaluation Criteria Development and Application ....................................... 3

Preliminary Research of the Most Promising Feedback.................................................. 3

Feedback Data and Analysis ................................................................................... 4

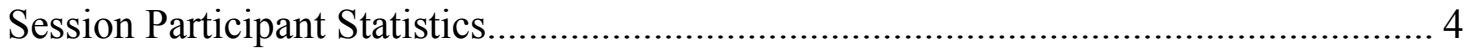

Summary and Analysis of Stakeholder Feedback ………………………………….... 5

Evaluation of Industry Stakeholder Feedback ............................................................... 6

Stakeholder Feedback Data Sorted by Evaluation Criteria.............................................. 6

Most Promising Recommendations from Industry Stakeholder Feedback..................... 7

Preliminary Research Findings of the Most Promising Industry Recommendations ..... 8

Current State of the Industry and Estimated Energy Savings for Recommended

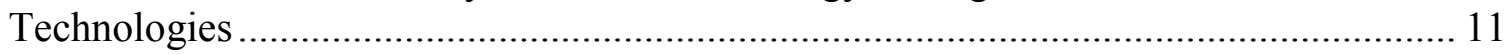

Improved Forced Air Distribution Systems Research ................................................. 11

Home Automation and Energy Monitoring Research ................................................. 24

Best Practices for Reducing Air Leakage Through Recessed Can Lights Research .... 29

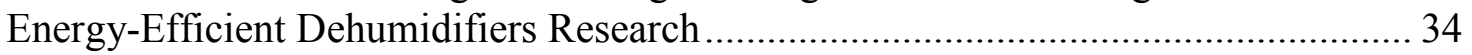

Energy-Efficient Furnace and Air-Handling Cabinets Research.................................. 38

HVAC Fault Detection Research.............................................................................. 41

Appendix A: Existing Homes RD\&D Stakeholder Feedback Questionnaire..................... 47

Appendix B: Existing Homes RD\&D Stakeholder Feedback ........................................... 49

Appendix C: Existing Homes RD\&D Stakeholder Feedback by End-Use Category (and

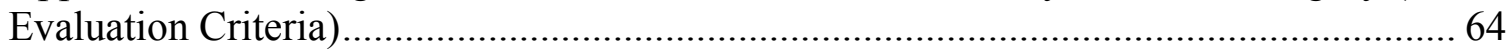

Appendix D: Existing Homes RD\&D Stakeholder Feedback by Evaluation Criteria...... 73

Appendix E: Technology and Best Practices Research for New Construction and Major

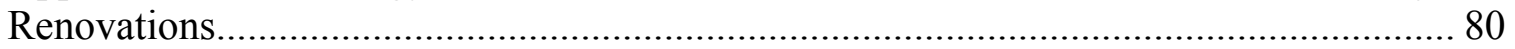

Self-Sealing Building Components...................................................................... 80

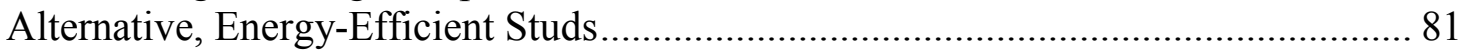




\section{Introduction}

In mid-2005, the U.S. Department of Energy (DOE) directed the National Renewable Energy Laboratory (NREL) to solicit and obtain feedback from building practitioners on the direction of future DOE research and development in the area of improving energy use in existing residential buildings. The Building Technologies Program (BTP) within DOE specifically sought feedback from stakeholders on which technologies and best practices the program should pursue. Industry stakeholders included: home remodelers and builders, home energy raters, HVAC contractors, home performance contractors, insulation installers, manufacturers, building scientists, and other interested stakeholders.

\section{Approach}

\section{Feedback Session Design and Conference Selection}

It was determined that sessions would be held at four key industry conferences between October 2005 and May 2006 to solicit the desired stakeholder recommendations for future DOE existing homes research, development, and demonstration (RD\&D). The four leading industry conferences included:

- The Remodeling Show, Oct. 2005, Baltimore, MD

- Environmental and Energy Building Association Conference, Oct. 2005, Colorado Springs, CO

- RESNET Conference, Feb. 2006, San Antonio, TX

- ACI Home Performance Conference, May 2006, Austin, TX.

Each session was designed to be a two-hour, interactive event with a mix of industry professionals. Participants were allowed to fill out a one-page feedback form and to participate in the facilitated sessions. The feedback form is provided in Appendix A. Both the forms and sessions focused on the following five probing questions:

1. From your experience, what energy-related products (including building materials) could use improvement?

2. Based on your knowledge of current construction practices, which ones do you think need improvement to increase the energy efficiency of your projects?

3. If you could have any new, energy-related building product at your disposal, what would it be? Or are you aware of a building product that you would like to use that is not readily available to you yet?

4. What information or tools (e.g, software) do you need to design and sell more energy-efficient projects?

5. Do you have other comments that would help us define how we spend our research dollars to improve energy efficiency and increase the use of renewable energy in existing American homes? 
In order to educate attending industry stakeholders and to entice them to the sessions, presentations were made at each of the four conference sessions in addition to soliciting feedback. The presentations covered the following topics, although not all presentations were given at each session:

- Tax Credits of the Energy Policy Act of 2005 by NREL

- DOE R\&D by DOE

- ENERGY STAR ${ }^{\circ}$ by the U.S. Environmental Protection Agency

- Home Performance with ENERGY STAR by NREL

- Home Performance Technologies and Field Practices by N'SPECTS.

\section{Feedback Interpretation and Categorization}

Industry feedback was collected via written feedback forms and participant suggestions recorded on flip charts during interactive sessions. As anticipated, the information gathered was often cryptic in nature. As a result, it was necessary to "interpret" the individual feedback to some extent. This interpretation varied from the simple spelling out of abbreviated text to rewording feedback to clearly explain the intent of the input. A very common interpretation included changing feedback such as "insulation" to "improved insulation" and "walls" to "more energy-efficient wall systems."

Once the information underwent interpretive filtering, the feedback was categorized by end-use and then by evaluation criteria. The key end-use categories, which actually include more than pure end-use groupings, included:

- Envelope

- HVAC

- Distribution systems

- Lighting

- Appliances, motors, and pumps

- Water heaters

- Home automation

- Indoor air quality (IAQ)

- Renewable energy systems

- Fuel cell, power generation, power plants, and co-generation

- Water conservation

- Diagnostics

- Software

- Education, training, and outreach

- Marketing and advertising strategies

- Financing strategies

- Miscellaneous, crosscutting, and unknown technologies.

In some cases, feedback overlapped on more than one category. In these situations, the best category fit for the corresponding feedback was used. In other cases, the information 
provided by an individual in response to a single feedback question contained more than one recommendation for future DOE RD\&D. In this situation, the information was separated out according to its appropriate end-use category. The development and application of feedback evaluation criteria is described next.

\section{Feedback Evaluation Criteria Development and Application}

Upon close examination of the individual stakeholder feedback, it became evident that some of the recommendations were unclear, out of the purview of DOE's Existing Homes R\&D program or too generic in nature. Additionally, some products referenced were already in the marketplace, or were needed in the marketplace but to varying degrees. Accordingly, the evaluation criteria below were developed for use in ranking the feedback. The criteria refers to the nature of the feedback or the technology or best practice it references.

$1=$ Generic in nature - feedback is not specific enough to guide DOE's research

$2=$ Already exists in marketplace (at least in some form)

$3=$ Needed in marketplace (" $3+$ " = needed to a large extent; " $3-$ " = needed to a small extent)

$4=$ Classification unknown or feedback unclear

$5=$ Not applicable to existing housing or DOE cannot perform associated research

$6=$ Responsibility of other DOE program offices or federal agencies.

Under these criteria, a rank of 3+, 3, or 3- indicates that DOE could consider the recommendation for targeting its future existing homes RD\&D, with $3+$ indicating the most promising technology or best practice area to pursue.

Besides the more obvious ranking of feedback for being unclear, too generic, or outside the realm of the BTP, individual feedback were ranked based on the principal investigators' extensive knowledge of the home building and renovation industry and marketplace, as well as on multiple stakeholders making the same recommendations. However, it is important to note that there is still a degree of subjectivity in feedback rankings between 3+, 3, and 3-. In addition, DOE can compare its current and planned RD\&D with all level 3 rankings to see where it aligns with industry feedback.

\section{Preliminary Research of the Most Promising Feedback}

To assist DOE in the initial review of industry RD\&D recommendations, NREL performed preliminary research on the state of the most promising technologies and best practices suggested. Stakeholder feedback assigned an evaluation criteria of $3+$ were researched through limited Internet searches of industry Web sites and an evaluation of existing related research. This preliminary research was designed to better describe the current state of the industry and to estimate the energy savings potential for each technology area. Web sites reviewed included those of manufacturers; associations; federal, state, and local governments; retailers; home remodelers and builders; building science firms; media; and others. Association sites included the Alliance to Save Energy 
(ASE), the Consortium for Energy Efficiency (CEE), the American Council for an Energy Efficient Economy (ACEEE), the Sheet Metal and Air Conditioning Contractors National Association (SMACNA), and several others associations. Federal government research extended to the Web sites of the U.S. Department of Housing and Urban Development's (HUD) Partnership for Advancing Technology in Housing (PATH), the National Institute of Science and Technology (NIST), and the U.S. Department of Energy's Building America Program.

\section{Feedback Data and Analysis}

\section{Session Participant Statistics}

A total of about 135 industry stakeholders participated in the feedback sessions held at the four conferences, which broke down as follows:

- The Remodeling Show - approximately 30 participants

- Environmental and Energy Building Association Conference - approximately 15 participants

- RESNET Conference - approximately 40 participants

- ACI Home Performance Conference - approximately 50 participants.

Figure 1 below shows the approximate split of participants by their respective affiliation.

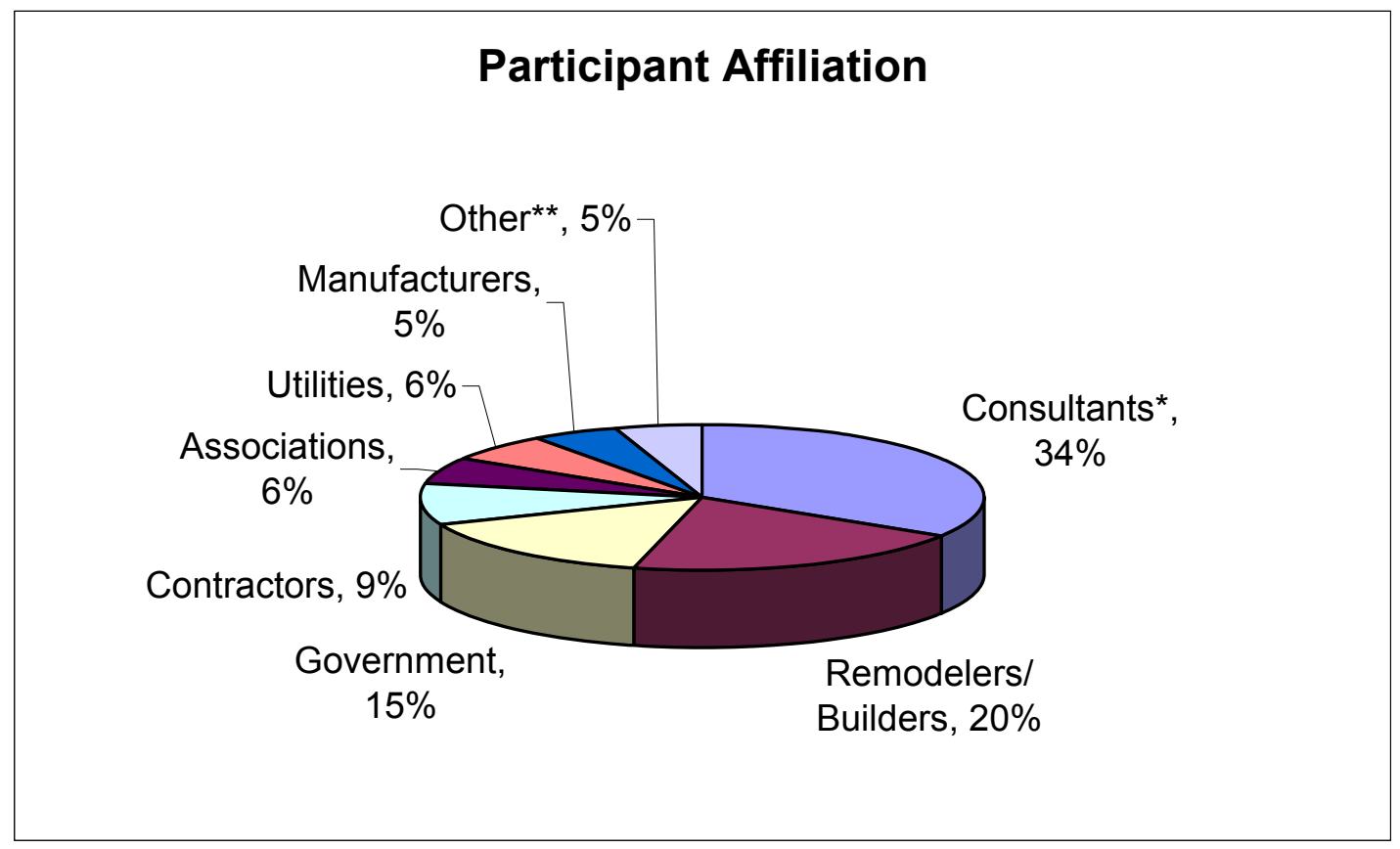

Figure 1. Feedback participants' affiliations

* "Consultants" includes individuals and firms engaged in energy efficiency consulting, engineering, building science, home energy ratings and inspections, and architecture.

** "Other" includes the media, retailers, lenders, and universities. 


\section{Summary and Analysis of Stakeholder Feedback}

The original (raw) existing homes RD\&D stakeholder feedback is presented in Appendix B. This feedback is sorted by conference and totals 181 recommendations. To place the information in a more useful form, Appendix $\mathrm{C}$ shows the same feedback by major enduse category (and by evaluation criteria ranking discussed in the next section). To improve clarity, Appendix $\mathrm{C}$ feedback includes interpretive enhancements to the feedback and the separation of certain feedback as described in earlier sections. Based on this separation, a new total of 340 individual recommendations were identified - nearly double the original total.

Each of the sessions at the four conferences resulted in varying levels of feedback from the industry participants. As partially reflected in figure 2 below, RESNET provided DOE with the most feedback and some of the best overall discussions. The EEBA conference, on the other hand, provided the least feedback, partially due to the lower attendance of the session.

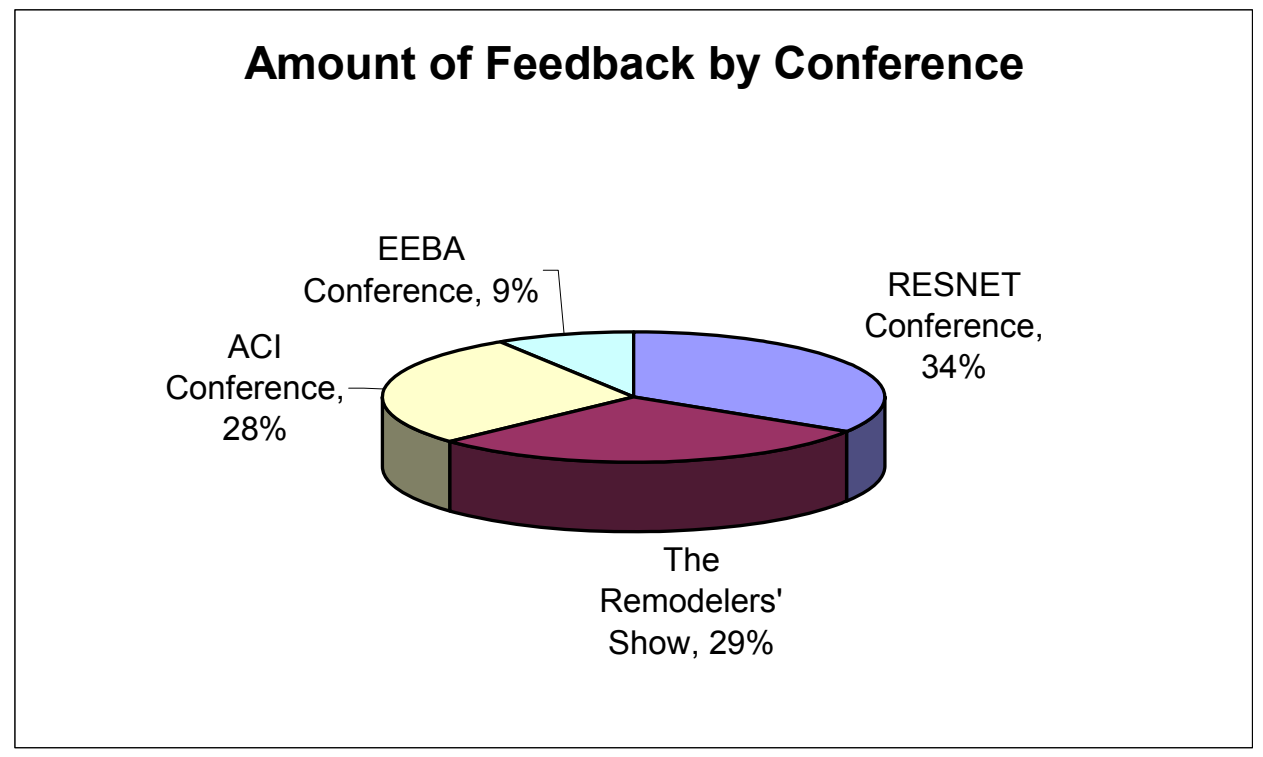

Figure 2. Percentage of feedback obtained from each conference

By plotting the feedback by end-use category (as defined earlier), one can quickly determine the major areas where the industry participants see needed increased existing homes R\&D. Figure 3 below illustrates this point. Not surprisingly, envelope and HVAC systems alone represent where a third of the feedback was targeted. Deployment, in the form of education, training, and outreach, and home automation accounted for another $21 \%$ of the overall feedback. Even though the sessions and feedback forms focused on $\mathrm{R} \& \mathrm{D}$, deployment was high on the list for these industry stakeholders.

Lower on that list, were research areas related to home energy efficiency such as indoor air quality and water conservation, as well as strategies involving financing and marketing. Interestingly, software and lighting did not merit much feedback, possibly suggesting some level of maturity of these tools and product lines in the marketplace. Moreover, there are many components to a home's envelope and HVAC systems, but, on 
the surface, there are comparably less facets to software tools and lighting systems. The other end-use categories and components of a home (such as appliances, distribution systems, water heaters, etc.) each received between $3 \%$ and $8 \%$ of the feedback.

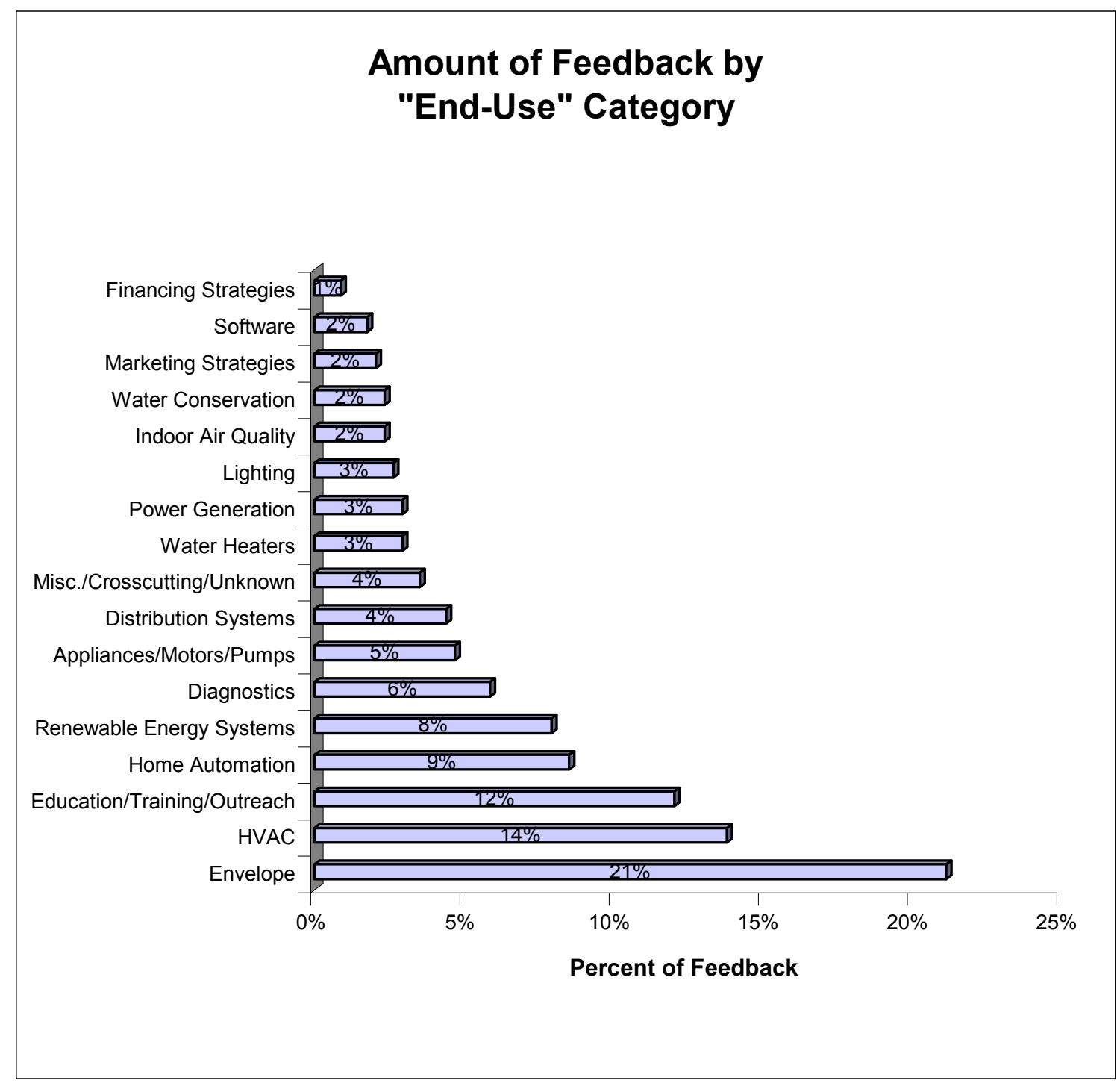

Figure 3. Percentage of feedback by end-use category

\section{Evaluation of Industry Stakeholder Feedback}

\section{Stakeholder Feedback Data Sorted by Evaluation Criteria}

In the previous section, industry feedback was analyzed as it pertained to end-use categories. To aid that analysis, Appendix C listed feedback by end-use category. The same appendix also presents the evaluation criteria ranking (1-6) assigned to each of the 340 industry recommendations. Appendix D shows the feedback sorted solely by evaluation criteria. Figure 4 below illustrates the percentage of feedback assigned to each evaluation criterion. As seen in this chart, nearly half of the industry recommendations for existing homes RD\&D related to technology and best practices needed to some level 
in the marketplace. Almost 30\% of the feedback referenced products and services currently available in some form in the marketplace; although, in several cases, additional product development could still be warranted (e.g., cost engineering.) The remaining $25 \%$ or so of RD\&D recommendations were unclear, too generic in nature to rank or categorize, or generally not under the purview of the Existing Homes R\&D Program (e.g., "more forgiving siding".)

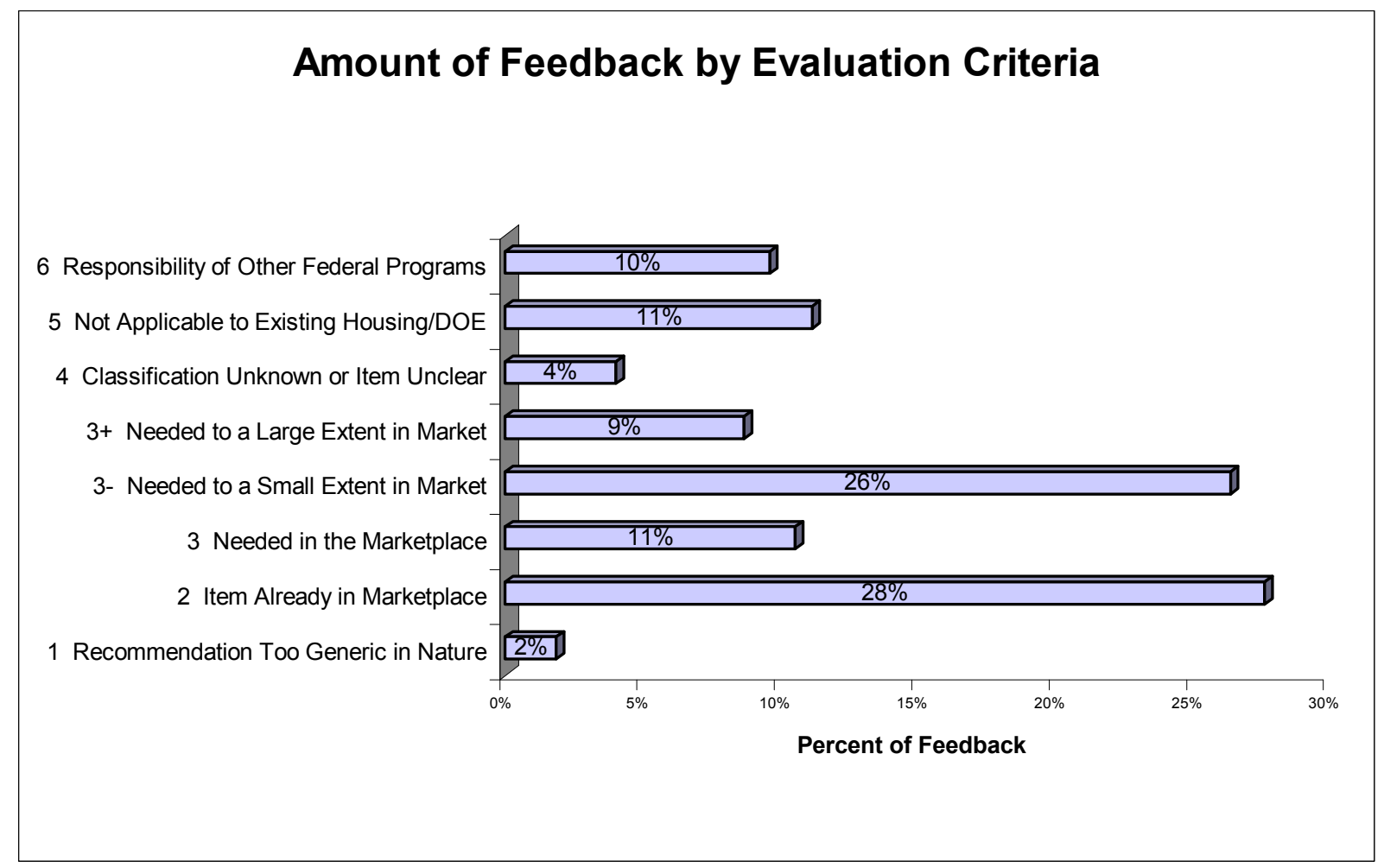

Figure 4. Percentage of feedback by evaluation criteria

\section{Most Promising Recommendations from Industry Stakeholder Feedback}

For the purposes of DOE's Existing Homes R\&D Program, the feedback receiving an evaluation criteria ranking of 3,3-, and 3+ are of the most interest to the program. However, there are 28 individual RD\&D recommendations alone assigned the $3+$ ranking - representing the RD\&D needed the most for technology and best practices to reach the marketplace. Given the program's finite resources, these 28 recommendations became the focus of this report. However, those industry recommendations receiving a ranking of 3 and then those with 3- are worth reviewing for future use.

The 28 recommendations discussed above were consolidated into the following six most promising areas of DOE existing homes energy efficiency research, development, and demonstration:

1. Improved forced air distribution systems

2. Home automation and energy monitoring

3. Best practices for reducing air leakage through recessed can lights 
4. Energy-efficient dehumidifiers (stand-alone and whole-building)

5. Energy-efficient furnace/air conditioning air-handling cabinets

6. HVAC fault detection.

In addition, two recommended areas - self-sealing building components and alternative studs (having a better R-value than conventional wood or steel studs) - although having potential to increase energy efficiency, were determined to be more appropriate for new construction. These technologies could be used in existing homes when there is a major renovation or rehabilitation. A brief discussion of the current state of the industry for these two technologies is included in Appendix E.

Although the above six areas are not listed in any particular order, developing improved distribution systems and practical home automation (for managing energy usage) were among the most popular recommendations in the feedback sessions. Unexpectedly, energy auditing tools were not overwhelmingly volunteered by session participants as an area needing additional research and development.

Very little specificity was provided in the feedback received from industry. This level of feedback was not unexpected nor was it considered insufficient. Session participants were allowed to volunteer what area they thought needed improvement or attention by DOE in the existing housing industry, without the requirement of specifying the exact technology solution. This approach allowed feedback discussions to flow and cover a wide range of topics.

Additional studies will be required by DOE to ascertain which specific technologies (or best practices) within each of the eight overall industry recommendations should be researched further and which exhibit the most energy savings potential. To initially aid DOE in the identification of specific technologies and industry practices, preliminary research was performed and is presented below. Besides this preliminary research or the need for additional studies, DOE may already have performed research into selected components of the six most promising areas above, in which case, the industry feedback can be used to affirm DOE's current course of RD\&D.

\section{Preliminary Research Findings of the Most Promising Industry Recommendations}

Research findings on the most promising industry-recommended technologies and best practices areas are presented in the following section. The information provided contains preliminary Internet research on the state of existing technologies, commercialization of products in each technology area, and recommended technology and best practices areas to be pursued for future research. Readers are highly encouraged to review this initial research to gain a better perspective on the potential technologies and best practices that could be researched and improved for the existing housing marketplace. More exhaustive background research should be performed as DOE narrows its focus to three or four of the above technology areas (especially on current manufacturer R\&D.) 
The preliminary research can be summarized as follows for each of the industryrecommended technology areas.

\section{Improved Forced Air Distribution Systems}

New products and applications need to be developed to improve the overall performance of heating and cooling forced air distribution systems. Performance problems with ducted systems can be the source of unnecessary energy loss, comfort problems, and may even contribute to indoor air quality and durability problems in homes caused by leakagedriven pressure imbalances. There are some new systems under development and some that are commercialized with limited market penetration. The commercially available systems use rubberized O-rings that fit between interlocking round ductwork, including SPIRAmir ${ }^{\mathrm{TM}}$ and PEGITTM. Sealants, such as Aerosol ${ }^{\mathrm{TM}}$, are new to the market and can be used to seal leaks from the inside of ductwork. Also, more training on the installation and sealing of conventional systems is needed. For example, traditional methods of using duct tape to wrap duct joints have limited longevity and building cavities are still widely used as a substitute for ductwork when installing systems in existing homes. UL181 tape, mastic, and duct ties have begun to replace duct tape as the best practice for sealing ducts. However, most residential ductwork installations are still customized for each home and prone to excessive thermal and air leakage.

\section{Home Automation and Energy Monitoring}

Many new automation systems are hitting the residential marketplace, most of which have some features to monitor and manage home energy use. Recent studies indicate that energy savings can be readily achieved through the use of feedback systems which make the homeowner more aware of how their habits and behavior impact their energy usage. In the U.S., there is still not a single standard or protocol for a home's various energyconsuming systems to effectively "talk" to each other and communicate with a wholehouse energy monitoring system. Currently, the Zwave $®$ and Zigbee ${ }^{\circledR}$ protocols are gaining momentum and may bring home automation mainstream in the next few years. All this combined, home automation is still confusing to builders and homeowners alike but holds great potential in the near future, thanks to wide-scale availability of broadband communications and affordable wireless networking devices.

\section{Best Practices for Reducing Air Leakage Through Recessed Can Lights}

Recessed can lights are more popular than ever and can contribute to both energy losses through unsealed cans as well as moisture migration into attic spaces. Sealed can lighting is in the marketplace but can be expensive; and practitioners do not always understand the difference between insulation contact (IC) rated fixtures and truly airtight fixtures. Also, there is no easy way to seal existing can lighting that penetrates the attic. Current industry best practice involves custom building a drywall box in the attic around the can light fixture and then sealing its seams with spray foam or caulk - an effective, inexpensive, but time-consuming approach . Additional research to develop alternative solutions to seal existing can lighting is much needed. 


\section{Energy Efficient Dehumidifiers (Stand Alone and Whole Building)}

Stand-alone dehumidifiers are still very inefficient and can contribute as much as $50 \%$ to a homes electrical baseload during peak usage periods. Central system dehumidifiers are coming into the marketplace but have not been developed with energy efficiency as a key attribute. Central systems also rely on existing heating and cooling duct systems for distribution, requiring the use of the central air-handler fan to distribute conditioned air throughout the house. While providing centralized dehumidification is an attractive option, unless a high efficiency fan is part of the existing distribution system, these systems can cost even more to run than stand alone dehumidifiers. To reduce the energy burden associated with these devices, additional research to improve the efficiency of dehumidification appliances is needed in addition to improved practices for diagnosing and managing moisture problems at the source.

\section{Energy Efficient Furnace and Air Conditioning Air-handling Cabinets}

The highest pressures in any air distribution system occur in the area closest to the blower fan. As a result, there is a high energy penalty for leakage in the area closest to the fan. Furnace and central air conditioning air handling cabinets are notoriously leaky as the removable panels designed for maintenance access invariably do not fit tightly and may become leakier over time with wear and tear. Access openings for filters are often found with ill-fitting or missing covers which are difficult to effectively seal and still provide access for cleaning and replacement. In addition to air leakage problems there are also opportunities to improve the efficiency of air handlers with more efficient motors, better fan blade design, and design of the housing around the fan.

\section{HVAC Fault Detection}

Faulty operation of HVAC systems including air-conditioners and heat pumps in residential buildings is prevalent and results in increased energy use. Common faults are incorrect refrigerant charge, incorrect airflow, evaporator fouling (dirty indoor air-filter), and condenser fouling (dirty outdoor coil). Handheld indicators are available for HVAC contractor use but few system-integrated indicators were found for homeowners to be alerted when maintenance is required in their central air conditioners. Those that do exist focus primarily on indicating when filters need cleaning and do not address other basic performance issues. Improved controls to monitor key performance indicators including temperature and relative humidity (similar to a car's "check engine" light) can help reduce energy loss by encouraging homeowners to have their systems serviced as soon as it is needed instead of waiting until a catastrophic failure occurs. 


\section{Current State of the Industry and Estimated Energy Savings for Recommended Technologies}

The 340 industry recommendations for additional existing housing research and development were screened and analyzed to reveal six of the most promising possible RD\&D areas. The six remaining technologies are described in greater detail below including a discussion of the current state of the industry, most promising emerging technologies, estimated energy savings potential, and technical risk. This research covers the topics listed below:

- Improved forced air distribution systems research

- Home automation and energy monitoring research

- Best practices for reducing air leakage through recessed can lights research

- Energy-efficient dehumidifiers (stand alone and whole-building) research

- Energy-efficient furnace and air-handling cabinets research

- HVAC fault detection research

Certainly, more exhaustive research will need to be performed (especially current manufacturer R\&D) as DOE narrows its focus to three or four of the above technologies. Much of the text on the following pages has been compiled directly from industry websites, with sources of the information given at the end of each section.

\section{Improved Forced Air Distribution Systems Research}

Improved air distribution systems have been identified by industry stakeholders as an area of research and development where DOE resources could provide significant benefit to existing homes. Specific recommendations included developing insulated and leakfree ductwork, better seals at duct joints, improved flexible (or flex) duct (e.g., such as Miracle flex duct), improved air registers, and generally new types of duct or air distribution systems and in situ sealing techniques.

\section{Types of Ducts}

Air distribution ducts are commonly constructed from sheet metal (older homes), rigid fiberglass duct board, or flexible duct (newer homes). Duct system installations that use the house structure or building framing (e.g., building cavities, closets, raised-floor air handler plenums, platform returns, wall stud spaces, panned floor joists) as supply or return ducts can be relatively inexpensive to install. However, they should be avoided because they are difficult to seal and cannot always be insulated. In addition, because they tend to be rough and have many twists and turns, it is difficult to build them to ensure good air distribution. Duct systems connected to building cavities can also contribute to increased envelope leakage due to pressure imbalances created when the forced air system is running. 
Flexible nonmetallic duct (or flex duct) consists of a duct inner liner supported on the inside by a helix wire coil and covered by blanket insulation with a flexible vapor-barrier jacket on the outside. Flexible duct is factory-insulated and has fewer duct connections and joints. However, flexible duct is easily torn, crushed, pinched, or damaged during installation. It has the highest resistance to air flow. Consequently, if used, it must be properly installed which is unusual in typical homes. To the contrary, flexible duct is commonly used as a means to get around obstructions resulting in long, twisted runs.

HVAC fittings are still made of sheet metal, just as they have been since the 1920s. Some of these fittings have been improved in recent years including the introduction of adhesive gaskets where flat surfaces connect; however, standard finger-tab connectors are still commonly used with no sealant and can be the source of major duct leakage for systems with any kind of round takeoffs including metal and flexible duct.

Two types of ducts that have emerged in the marketplace over the years are described below: flexible duct systems and fibrous glass duct board.

\section{Flexible Duct Systems}

The next few paragraphs discuss pressure drops specifically associated with flexible duct systems and explains the difficulties of measuring such losses. The discussion is excerpted from a Lawrence Berkeley National Laboratory report entitled: A Study of Pressure Losses in Residential Air Distribution Systems (2002).

The installation of air distribution systems and the type of duct fittings used, play a major role in the overall system performance. It is crucial for the designer and the contractor to realize the impact that pressure drop in flexible ducts and fittings can have on the power consumption and the overall performance of the HVAC system. Pressure losses in an air distribution system are balanced by pressure increases at the installed fan. It is very important that every feasible means be used to control the fan power use. Increased flow resistance in the ducts results in an increase in pressure drop, therefore lower airflow. This leads to increased fan power use and lower heat exchanger efficiency (due to a lesser capacity). The combination of these effects can significantly increase power and energy consumption. Designing and properly installing duct systems that are energy efficient is, therefore, instrumental in achieving an overall energy efficient HVAC system.

In field studies, observed pressure drops in flexible duct systems are often higher than expected (based on design calculations) because the flexible ducts are often found to be compressed to varying degrees. This common problem leads to excessive pressure drop in many systems, with associated fan power, flow restriction, and noise issues. For design purposes and for diagnosing duct systems, engineers and analysts consult friction charts and matching friction loss coefficients from references. For fully stretched flexible duct in particular ASHRAE Fundamentals (ASHRAE 2001) and Air Conditioning Contractors of America Manual D (ACCA 1995) - they provide pressure drop calculations. However, when it comes to the compression effects on flexible ducts, the available literature does 
not provide enough resources for a good estimate of pressure drop in a duct system. ASHRAE Fundamentals provides a graph, showing how compressing a fully stretched flexible duct increases the pressure drop. This single graph is used for all sizes of flexible ducts, and there is no friction chart provided.

ASHRAE Fundamentals (ASHRAE 2001) suggests the use of the friction loss equation with the Altshul-Tsal equation of friction factor (Altshul and Kiselev 1975, and Tsal 1989), for the calculation of pressure drop in flexible ducts - the problem with using ASHRAE friction drop equations is in estimating the correct value of the absolute roughness, because roughness data for flexible ducts are generally not available. ASHRAE Fundamentals categorizes the roughness in five categories (smooth, mediumsmooth, average, medium-rough, and rough) and provides a general absolute roughness value for each category. It also provides a range for the roughness of each type of duct in each category. Flexible duct (all types of fabric and wire) are considered medium-rough to rough, with an absolute roughness range of $0.0035-0.015 \mathrm{ft}(1.0-4.6 \mathrm{~mm})$ when fully extended. No guidance is provided to select values corresponding to different compression ratios. When the flexible duct is compressed, the inner surface gets crumpled and the effective surface roughness increases orders of magnitude above the range provided in ASHRAE Fundamentals. For the designer, even using an appropriate model for the friction factor and surface roughness, would be problematic since having the appropriate value of the roughness for the specific compression case of the flexible duct is not available.

\section{Fibrous Glass Duct Board}

Fibrous glass duct board is 1-, 11/2-, or 2-inch thick rigid boards of insulation material manufactured from resin bonded inorganic glass fibers. This bonding keeps the fibers in place through the life of the installation. The exterior surface of the board is a factoryapplied reinforced aluminum foil air barrier and water vapor retarder. Fibrous glass duct boards are fabricated into ducts to make a fibrous glass duct system.

Four companies in the U.S. produce duct board. All manufacturers produce a basic fibrous glass duct board with the core material exposed to the air-stream with no additional coating. A higher performance duct board is produced by laminating a facing, adding a coating, or a combination of both to the inside surface. As North American Insulation Manufacturers Association (NAIMA) reports (1998), fibrous glass duct board may be cleaned with conventional methods. Fibrous glass duct board complies with UL 181 and is a Class 1 duct system. UL 181 tapes are typically used to seal the seams in duct-board systems, which can be a challenge to install properly in existing homes. To attain proper adhesion, these tapes require a clean surface and use of a squeegee. Ductboard systems in residential applications are typically combined with flexible duct takeoffs, resulting in leakage areas where two dissimilar materials are joined together (e.g. flexible ducts connected using metal collars attached to a duct-board trunk, or a ductboard plenum connected to a metal air handling cabinet.) 
The main advantage of fibrous glass duct systems is that the duct has thermal insulation and does not require external insulation. Fibrous glass duct board is rigid, which allows the ducts to hold their shape and be suspended much like metal duct. When following the Sheet Metal and Air Conditioning Contractors' National Association's (SMACNA) (1992) recommendations for installation, ducts will be relatively airtight, durable under most applications, resistant to microbial growth, and quite effective at attenuation of duct-borne noise at high frequencies. According to NAIMA (1996), the fibrous glass duct's outer jacket acts as a vapor retarder to help control moisture condensation in the air-handling system, thus reducing the opportunity for water damage, or for microbial growth and amplification.

Based on tests performed by NAIMA using Underwriters' Laboratories (UL) test procedures, fibrous glass duct board is a strong and durable material system. Laboratory tests confirmed that fibrous glass ducts do not support mold growth and that mold growth is not surface specific; HVAC systems may create conditions that are suitable for mold growth on any duct material. The attributes of fibrous glass duct board reduce noises more than sheet metal In addition, attachment of insulated flex duct to fibrous glass ducts is as simple as spinning in a collar, sealing the pressure liner, and securing the vapor retarding covering to the facing of the fibrous glass duct board.

There are some specific areas within the duct system where fibrous glass duct board may not always be the recommended product because of the high potential for exposure to water such as for down-flow furnaces. Sheet metal should be used directly below the unit and then for four feet in the ductwork adjacent to the coil plenum. Standard uncoated fibrous glass duct board may be used after the first four feet of coated duct.

Correctly sizing the system is also very important since the calculated pressure drop for fibrous glass duct board is higher than that of sheet metal ductwork of the same criteria, and grows as the airflows increase. At the lowest calculated airflows, fibrous glass duct board has an average of $30 \%$ more pressure drop.

\section{Duct Losses}

Losses in the duct system are due to conduction loss (poor insulation) or air leakage. Measurements of energy losses from ducts have shown that in most houses this leakage is more important than conduction losses. Ducts are usually made from sheet metal (more common in older houses) or flexible plastic duct (used in almost all new houses). Little or no air leaks out through the plastic or metals walls of these ducts. The air leaks out at the connections: from the furnace and air conditioner to the duct, at branches in the duct system, and at connections from the duct to the registers. In a sample of over 700 homes, new and old, tested for duct leakage in Connecticut from 2006-2007 by Steven Winter Associates, Inc., leakage to outside ranged from $50 \mathrm{cfm}$ at 25 Pascals of pressure (or virtually no measurable leakage) to leakage in excess of $1500 \mathrm{cfm}$ at 25 Pascals (i.e. leakage so high it is outside the range of accuracy for the measurement device used). It is virtually impossible to predict leakage rates without testing because visual inspection provides only limited clues as to what is happening throughout the entire duct system. 
Duct leakage is the result of improper installation and poor materials. Duct tape, which is commonly used, does not adequately seal joints between ducts and has a short life. More stable and permanent materials are needed such as foil tape, fiberglass tape and mastic, or new advanced duct tape. Locating the ducts within the conditioned space can also improve system efficiency. Even when ducts are located within conditioned spaces, sealing is still required to assure proper air distribution.

\section{Current Duct Sealing and Insulating Options}

\section{Tapes and Mastic}

Metal-reinforced tapes and mastic approved by Underwriters Laboratories (UL181, etc.) are the preferred, conventional choice for sealing ducts. Mastic is rubbery, fiberreinforced material similar in texture to joint compound that is applied manually. Holes larger than $1 / 4$ inch are typically reinforced with fiber-mesh tape before sealing with mastic, and very large holes are generally patched with sheet metal or duct board and then sealed with mastic. Ducts are still often sealed with standard duct tape, but, despite its name, duct tape is a poor material for that purpose.

\section{Aerosol Sealants}

A technology sold under the trade name Aeroseal by Carrier Corp., and originally developed by DOE has the potential to dramatically mitigate leaks and the problems they cause. It works by blowing an aerosolized adhesive into ducts. The particles attach themselves to the edges of leaks and effectively seal them. Sold as part of a franchised service that includes diagnostics, repair, safety testing, sealing, and reporting, Aeroseal is the only technology on the market that can seal leaks in ducts made inaccessible by walls and insulation. However, for large holes one should use the traditional methods. Although Aeroseal is a promising technology for many existing homes applications, it requires a relative large free area around the air handler cabinet to set up the equipment and for practical purposes is limited in its ability to seal holes much larger than $1 / 4$ inch (mainly due to the time it takes for the particles to build up and seal larger openings.)

\section{Insulation}

The need for insulation can be reduced if the ducts are located within the conditioned space. In this location, any conductive losses and gains would be minimal since ducts would be exposed to indoor air temperatures. Usually ducts are only insulated if they are outside the conditioned space. Older duct systems made of sheet metal are often found in basements and have no insulation. Some of these older sheet metal ducts have an asbestos based thin layer of insulation added to them. This thin layer of asbestos gives the ducts a small increase in thermal resistance. Occasionally, these poorly insulated sheet metal ducts can also be found in unconditioned spaces, such as attics or crawlspaces.

Ducts in new houses are often made of insulated flexible plastic duct. This duct is usually labeled on the outside liner with its R-value. The heat stopping ability of insulation is indicated by the R-value, with higher R-values denoting better performance. 
Most flexible plastic ducts have R4 insulation (compared to less than R-1 for uninsulated sheet metal ducts.) In some cases, a mixture of insulation will be seen. In recent years, innovative methods for insulating ducts have been developed. For example, ducts can be laid on the attic floor and blown over with spray foam or cellulose. When houses or heating/cooling systems are renovated, insulation is added to existing ducts, because it can be cheaper than replacing the ducts.

Fiberglass duct insulation is the most common insulation for ducts. Foil- or vinyl-faced fiberglass duct insulation fastens to sheet metal ducts by various fastening systems including:

- Staples and tape

- Welded pins and self-locking washers

- Glued on pins called stuck-ups or stick pins, with self-locking washers

- Twine wrapped around the insulation and duct, then stapled to nearby wood joists

- Plastic cable ties or tie wire.

Fiberglass duct board and insulated flex duct are duct materials with insulation built in. They are not as durable as metal ducts, but are easier to build and install, so they are common. They must have a larger cross-sectional area compared to metal ducts, because they are rougher inside and therefore create more air resistance. If using an internal duct liner, it is recommended to use a new type of duct liner (instead of the Fiberglass fibrous glass or glass wool), which does not deteriorate, does not absorb moisture, and has a smooth and cleanable surface (various type polymers).

\section{Air Registers and Vents}

There are several improved air registers on the market, but none were found that stand out. Perhaps more critical than next-generation air registers is ensuring that the correct amount of air flows to each register from the home's HVAC system. The power delivered to the conditioned space via the air register is called Tons At the Register (TAR) (although this is a misnomer for heating systems, it is retained for convenience.) Higher TAR implies more energy delivered to the conditioned space. TAR is used as a comfort parameter because it changes the occupants perception of cooling system performance and also affects consumer expectations of how much heating or cooling the system should provide.

Correct air flow at a register translated to the HVAC system is able to keep the room comfortable. One major reason that system air flows tend to be too low is that installers (and equipment manufacturers) underestimate the flow resistance of the system. The system flow resistance tends to be high due to the use of flexible ducts that have high flow resistance (particularly if not stretched tight on installation), undersized ducts, and dirty filters and coils. However for cooling systems in humid climates, the air flow may be set deliberately low despite the associated energy efficiency penalty in order to increase the latent capacity of the equipment. 
Target air flows should be based on engineering calculations using standard techniques such as those published in Air Conditioning Contractors of America (ACCA) Manual J. Residential register air flow techniques range from the use of complex (but highly accurate) powered flow hoods, to simply timing how long it takes to fill a plastic bag. For system balancing, detecting disconnects or setting register flows, most of these flow hood measurement techniques are acceptable. However, note that most commercially available flow hoods are not accurate enough in residential applications, and something simple like bag filling is preferable.

Flow hoods have been used for many years in the HVAC industry as a method of measuring the air flows at registers. Until recently, almost all register measurements were made in non-residential buildings, usually as part of a testing and balancing procedure for the HVAC system. Most commercially available flow hoods were developed for use on non-residential systems with the register sizes and flow rates common to these systems. Residential HVAC systems were very rarely tested in the past; however, utility programs, weatherization programs, and codes and standards developments (that require commissioning of residential HVAC systems) are beginning to look at this important aspect of residential HVAC system performance. The register flows in residential systems are used to determine if individual rooms are getting the correct air flow, and in estimates of total air handler flow and duct air leakage.

Flow hoods from major manufacturers were recently tested by the Lawrence Berkeley National Laboratory (LBNL) together with a couple of active flow hoods and a propeller flow hood no longer in production (but still in use with residential air flow practitioners). Reference http://epb1.lbl.gov/EPB/Publications/lbnl-47382.pdf for the study's full findings. The following flow hood types were tested:

- Standard flow hoods that use fabric hoods over a collapsible rigid frame that directs the flow over a velocity sensing element

- Propeller flow hoods that have a rigid glass fiber flow capture section and are specifically developed for the smaller registers and flow in residential systems

- Active flow hoods that were originally developed to reduce the effects of back pressure on the flow measurement

- Non-standard flow hoods that use different methods for flow capture and sensing. The specific type tested in LBNL's study uses a flow capture device like a standard flow hood, and a novel flow capture, sampling and sensing technology.

A total of 13 flow hoods were evaluated by LBNL. The key conclusion from these laboratory tests was that active flow hood is very good for measuring register flows because it is not sensitive to incoming flow conditions; therefore, it can be used as a reference test method when studying the following field tests. All the other flow hoods exhibit large errors for different configurations of flow entry into the flow hood and are sensitive to register placement. This means that users of these flow hoods need to be very careful when placing hoods over registers and in many cases, where registers are placed near the intersections of walls, floors or ceilings (or in kicker panels, etc.) the measurement errors can become extreme. None of the other hoods have good enough 
results to be used to estimate duct leakage, air handler flow, overall system flow imbalances, or individual register flows for load and thermal comfort.

\section{Cost}

The homeowners typically pay in the range of $\$ 80$ to $\$ 120$ for duct testing and diagnostics. Mastic is available at Home Depot for about $\$ 16$ per gallon bucket. As Aeroseal franchisees gain experience and recoup their initial investments, their prices are likely to fall, which should shorten payback periods. Quicker paybacks can also be achieved where there is an increasing cost of energy. Sealing a furnace and its ductwork with Aeroseal should cost around $\$ 400$ in a new home, but closer to $\$ 800$ in an existing home.

\section{Codes and Standards}

According to the 2000 International Energy Conservation Code, ductwork must be sealed with mastic instead of duct tape. Although many states have adopted energy-efficiency codes in recent years that include a provision for sealed ducts in new construction, there is a long learning curve before truly sealed ducts become a reality in new residential installations. Contractors are typically not trained on proper duct sealing techniques and do not pressure test the systems once they are installed, resulting in ducts with mastic on them that are not, in fact, sealed. Building code inspectors, similarly, are unaware of what to inspect for when these codes are first introduced.

The following organizations also regulate air distribution systems:

- Sheet Metal and Air Conditioning Contractors' National Association, Inc. (SMACNA)

- Air Diffusion Council (ADC)

- North American Insulation Manufacturers Association (NAIMA)

- Underwriters Laboratory (UL)

- American Society for Testing and Materials Standards (ASTM).

All duct materials shall have a minimum performance temperature rating per UL181 (ducts), UL181A (closure systems for rigid ducts), UL181B (closure systems for flexible ducts and approved tapes) and/or UL 181BM (mastic), and shall have a flame spread rating of no more than 25 and a maximum smoke developed rating of 50 (ASTM E 84).

\section{Current Research and Test Results}

To confirm the anecdotal evidence regarding duct tape failures, Lawrence Berkeley National Laboratory (LBNL) developed a laboratory test procedure that alternately blows hot and cold air through sample duct connections. This test does not simulate what happens to ducts in a specific installation, but it does provide a basis for comparison between different duct sealants. LBNL tested 19 different sealants including: cloth, metal foil and plastic backed tapes, and mastic and an aerosol sealant developed at LBNL. The 
major result was that the only sealant to fail was the cloth-backed tapes (duct tape), but field examinations of ducts often find their seals failing over time. To provide lab data about which sealants and tapes last, and which are likely to fail, LBNL is conducting ongoing accelerated testing at its Environmental Energy Technologies Division. LBNL's major conclusion, so far, is that one should use anything but duct tape to seal ducts (duct tape is defined as any fabric-based tape with rubber adhesive.) The testing LBNL has done so far shows that under challenging but realistic conditions, duct tapes fail.

Massachusetts Institute of Technology's (MIT) House- $n$ project has been studying new types of ductwork and ductwork chases. In addition, DOE is currently researching air distribution systems, including the expanded use of PVC ductwork.

\section{New Technologies}

\section{Aerosol Sealant ${ }^{\mathrm{TM}}$}

A cutting-edge technique for sealing ducts is the aerosol sealant technology that was first developed at Lawrence Berkeley National Lab in 1994 (see http://epb.lbl.gov/aerosol/index.html). Aeroseal Inc. of Austin, Texas is working to commercialize this technology. The air sealing system results are guaranteed for 10 years. Aerosol sealing improves upon conventional duct-leak sealing methods because it:

- Seals more of the leakage by getting to inaccessible leaks

- Provides better working conditions so that workers do not have to spend a long time in the attic or crawl space to perform the sealing.

\section{Duct Systems}

Installing a traditional central heating and cooling system in homes with no existing ductwork can be cumbersome. Interior walls, ceilings, and floors may need to be modified to accommodate standard-sized air ducts. However, high velocity heating and cooling systems minimize these alterations by using two-inch diameter ducts that are small enough to mount in floor, ceiling, and wall cavities. According to the manufacturers, high velocity systems operate quietly and improve dehumidification, room air mixing, and energy efficiency over standard air-delivery systems. High velocity systems use standard outdoor condensing units for air conditioning and heat pump systems. In new construction, high velocity systems may cost more than standard air distribution systems. In existing homes, the labor cost savings of high velocity systems can result in an installed cost that is lower than standard heating and cooling systems. The Air Conditioning and Refrigeration Institute (ARI) certifies high velocity air distribution systems for use with the outdoor units of numerous heat pumps, air conditioners, and other heat sources.

Gas Filled Panel (GFP) technology of Griffith et al. (1992) was developed for use in duct systems and their qualities for manufacturing, ease of installation, and compressibility were evaluated. Their advantages include: they can be designed as ducts rather than add on insulations, can be made to compress completely for shipping, and can achieve a higher insulation level for a given thickness. 
The Haines System for ducts uses a duct very similar to flex but with a foam as the insulation. Consequently, it offers little advantage over flex duct and would not change the performance of duct systems.

\section{Cardboard Forms}

The Ultimate $\mathrm{R}$ is a system of cardboard forms that are placed over duct systems, which lay on joists in the attic. Cellulose is then sprayed over the duct to achieve an R-value of up to $39\left(\mathrm{hr} \cdot \mathrm{ft} 2 \cdot{ }^{\circ} \mathrm{F} / \mathrm{Btu}\right)$ with little effort. It is of interest how much savings will result from such a high insulation level but the technology is only useful where there is adequate space.

\section{Plastic Fittings}

There are two companies which are producing plastic fittings that attach to insulated flex duct. The advantages of the fittings are: insulation is incorporated into their design, they are less likely to be bent or torn, and they can't leak along seams like sheet metal fittings. One of the plastic fittings, Flexmate (in the prototyping phase in 1995 but no other information found recently), is designed to easily be mounted to joists. This could reduce the number of supports needed for the ductwork.

\section{Self-Sealing Duct Systems}

SPIRAmir ${ }^{\mathrm{TM}}$. The SPIRAmir ${ }^{\mathrm{TM}}$ self-sealing duct system claims to save $15 \%$ to $25 \%$ on field-installation costs. Exclusively available in Oregon and Washington from Streimer Sheet Metal Works, Inc., the system effectively joins round duct and fittings without sealants or duct tape, thus reducing installation time - by as much as $25 \%$. The SPIRAmir ${ }^{\mathrm{TM}}$ self-sealing duct system utilizes a soft rubber O-ring on each fitting, enabling fittings to smoothly slide in place and form tight seals when duct connections are made. These tight seals ensure cleaner air quality and enhance energy efficiency. In the unlikely event an O-ring is damaged, a new O-ring can easily be slipped on, assuring that the self-sealing system remains intact. SPIRAmir ${ }^{\mathrm{TM}}$ fittings are available in galvanized steel, stainless steel, PVC coated steel, aluminum, and other special materials.

PEGIT. Proctor Engineering Group (PEG) is developing a system of joining ducts (called PEGIT) that combines the mechanical fastening and sealing into a single selfcontained procedure. The PEGIT system uses a shaped flexible seal between specially designed sheet metal duct fittings to both seal and fasten duct sections together.

During this study, the PEGIT system has been evaluated for air leakage and ease of assembly and disassembly. Ideally, the system would have as little leakage as possible, be easy to assemble, and difficult to take apart. Significant changes were made by Proctor Engineering to the design of the PEGIT system to improve the air seal and ensure that it stayed in the sheet metal fitting. However, the final results indicate that achieving air leakage equal to or less than a conventional duct fitting sealed with tape requires such a tight fit between the inner and outer duct sections that the resulting assembly forces are 
greater than $50 \mathrm{lbf}$. This assembly force seems too large if systems are to be field assembled.

Since many new and replacement duct systems use flexible ducting, the force it took to disassemble flexible ducting from a conventional inner duct and a PEGIT inner duct was also tested. The results show that the PEGIT sheet metal fitting is as good as a conventional duct fitting for attaching flex duct cores.

SPIROsafe. Lindab has developed a new type of duct sealing. SPIROsafe round duct includes a double-lipped EPDM seal that eliminates the need for additional sealants, such as tape or mastic. Extreme temperatures and moisture have no effect on installation. Installers simply slip the ducts and fittings together, reducing labor costs (and mess). The seal created by the factory-installed, EPDM rubber gaskets exceeds SMACNA Leakage Class 3 requirements from $+12 " \mathrm{WG}$ to $-20 " \mathrm{WG}$ without additional duct sealants. The gaskets are also tested in accordance with ASTM E84-91a (aka NFPA 90A) for conformance with flame spread (FS) and smoke development (SD). SPIROsafe gasket material is UL classified with ratings of $\mathrm{FS}=0$ and $\mathrm{SD}=5$. The SpiroSafe product line includes a single wall and double wall spiral duct, elbows, Y-branches, reducers, tees, end caps, saddle taps and other fittings.

Plastic Ducts. Using rigid-plastic ductwork could be a good way to solve the problem of leaky ducts. Plastic ducts - also known as thermoformed ductwork - feature tight joints, rounded bends, and smooth inner surfaces. These characteristics could virtually eliminate leaks and reduce friction losses. In 2004 with a Small Business Innovation Research (SBIR) grant from DOE, Steven Winter Associates (SWA), a DOE Building America partner, installed a first-generation rigid-plastic ductwork system in a new home in Georgia to test the product's performance. The ducts were manufactured in prefabricated parts by ATS Duct Systems of California.

The goal was to come up with a residential duct system that is not only free of leaks but is also cost-effective and easy to install. According to SWA, early evaluations indicated that plastic ducts provide significant benefits when compared with conventional sheet metal, flex duct, and duct-board systems:

- Rigid-plastic ducts are virtually leak-free because they have fewer joints and the solvent bonding process is likely to produce a leak free joint.

- Their smooth interior surfaces and curved take-offs and turns result in lower friction losses in comparison to conventional systems; this means that smaller ducts could perform as well as larger conventional ones, also reducing material and operating costs.

- The ducts can be prefabricated to reduce the amount of effort and time required for installation on site.

- They can be cleaned easily, alleviating health concerns about accumulations of dirt and mold.

Originally designed for highly corrosive exhaust systems, the ATS prefabricated products are UL 181-listed and have a fireproof coating. As part of the demonstration, Bryant Company provided an upgraded FV4 variable-speed air-handling unit. Fantech Iris 
dampers were installed to help balance and test the system. The plastic ducts were insulated with a polyurethane spray foam. The home construction company, mechanical contractor, and local code inspectors all reacted very positively to the new system.

\section{Energy Savings Potential}

Given the wide variation in duct construction types, insulation techniques, and leakage rates in existing homes today, it is difficult to fully quantify the energy penalties experienced for inefficient duct systems. However, most studies and experts agree that energy loss attributable to inefficient duct systems is somewhere in the range of $20 \%$ $40 \%$ of the total heating and cooling load for the home. In ideal conditions, with near zero leakage and minimal conductive losses, this energy loss can be virtually eliminated. However, many existing homes have less than ideal conditions and require that new and innovative materials and techniques be developed to fully address the problem. One study determined that leakage rates for small diameter high velocity ductwork ranged from 3\%-9\% of the total system airflow, as opposed to $25 \%-75 \%$ leakage rates typically found in conventional metal/flex/duct-board systems. In addition, research conducted in Florida noted the potential for up to 30\% reduction of coincident peak electricity loads attributable to sealing ductwork on central air conditioning systems.

\section{Conclusion}

The main problems with flex ducts are sagging and being torn, crushed, pinched, or damaged during installation. Some additional research can be done to find a way to deal with these problems. In all other areas (cheaper, easier to install, factory insulated versus field insulated, etc.), flex ducts look superior to other types of ducts. There do not seem to be any major problems with air registers and vents.

Since air leakage occurs mostly at connections and the exiting sealants are appropriate and efficient, so perhaps more contractor training on installation and retrofitting would be beneficial. The research also suggests many contractors still use duct tape; so there is a problem in labor skills as well as existing products. Aeroseal and high velocity duct systems hold promise for existing homes applications but additional R\&D funding to help bring other products to market such as self-sealing systems and alternative solutions to the use of building cavities for ducts would also be helpful. Increased outreach and deployment of Aeroseal-type products to consumers and contractors could be performed as well. For example in Colorado there is only one Aeroseal contractor. Additional marketing of high velocity heating and cooling systems may also be useful. Ultimately, however, the marketplace is poised for new and improved, self-sealing and easy to install duct systems. DOE's Building America program brochure entitled Better Duct Systems for Home Heating and Cooling produced in 2004 (http://www.nrel.gov/docs/fy05osti/30506.pdf) addresses many of the topics above. 


\section{References}

ACCA. 1995. Residential Duct Systems. Manual D. Air Conditioning Contractors of America. Washington, DC.

ASHRAE. 1995. ASHRAE Standard 120P, Methods of Testing to Determine Flow Resistance of HVAC Air Ducts and Fittings, December 1995. American Society of Heating Refrigerating and Air-conditioning Engineers, Atlanta, Georgia.

"Air Distribution System Installation and Sealing", Technology Fact Sheet, Building Technologies Program, EERE/DOE.

"A Study of Pressure Losses in Residential Air Distribution Systems 2002," Indoor Environment Department, Lawrence Berkeley National Laboratory, http://www.osti.gov/bridge/servlets/purl/803766-kWqoON/native/803766.pdf

Best Practices Guide for Residential HVAC Retrofits

http://ducts.lbl.gov/HVACRetrofitguide.html

Delivering Tons to the Register: Energy Efficient Design and Operation of Residential Cooling Systems, 2000, http://www.osti.gov/bridge/servlets/purl/7718013QjIlM/webviewable/771801.pdf

Evaluation of Flow hood Measurements for Residential Register Flows, 2001 http://www.osti.gov/bridge/servlets/purl/791782-L4bxqQ/native/791782.pdf

Evaluation of PEGIT Duct Connection System

http://www.osti.gov/bridge/servlets/purl/816351-16QAm1/native/816351.pdf

Fibrous Glass Duct Board White Paper

http://www.eere.energy.gov/buildings/building_america/pdfs/db/35396.pdf

Fugler, D., "Duct Leakage Tests in Small Diameter Ducting Systems", Canadian Mortgage Housing Council, October 2005

Parker, D. and Cummings, J., “Will duct Repairs Reduce Cooling Load?”, Home Energy Magazine, Sep/Oct 1993.

Proctor, J., and Parker, D. 2000. Hidden Power Drains: Residential Heating and Cooling Fan Power Demand. Proceedings of the 2000 ACEEE summer Study on Energy Efficiency in Buildings. http://www.fsec.ucf.edu/bldg/pubs/pf361/

Simulation of Residential HVAC System Performance, 2001. http://www.osti.gov/bridge/servlets/purl/785278-tSflhr/native/785278.pdf

Treidler Burke and Mark Modera, "New Technologies for Residential HVAC Ducts", February 1995

Walker, I.S., Wray, C.P., Dickerhoff, D.J., and Sherman, M.H. 2001. Evaluation of Flow Hood Measurements for Residential Register Flows. LBNL 47382. 


\section{Home Automation and Energy Monitoring Research}

Home automation was suggested by industry stakeholders as another area of possible DOE RD\&D. Home automation was identified by stakeholders as including: home energy use monitors, advanced programmable thermostats and humidistats (interactive and adaptable), demand response for homes, energy use meters for individual appliances and equipment, real-time monitoring/metering, time-of-use meters, and radio frequency identification systems (RFID) controls for appliances and equipment.

\section{Metering}

Pay-as-you-go electricity involves a prepay device that gives customers a more visible and understandable means of controlling their energy consumption - in sharp contrast to the traditional postpaid metering systems that are very customer-unfriendly and promote energy inefficiency. With the Pay-as-you-go system, the utility connects a smart meter to the meter socket, and the customer plugs in a display unit into any electrical wall outlet in their home. The display unit communicates through the house wiring to the smart meter. The customer takes a smart card to the local variety store and buys power in any dollar amount he likes. The customer gets information from the display unit in real time. Customers are now in control of their electricity usage. They can see what each appliance is costing them as it cycles on and off, and even how much appliances are costing them in standby mode. Woodstock Hydro's statistics show that Pay-as-you-go customers use considerably less energy than post pay customers.

\section{Thermostats and Humidistats}

Honeywell has a large choice of programmable thermostats. Other large manufacturers in this area include White Rodgers, Robertshaw, ClimaTouch, AprilAire, and Lux Pro. Some manufacturers are now offering a programmable thermostat with humidity or dehumidification control and intelligent thermostat systems. For example, Aprilaire ${ }^{\circledR}$ markets a Communicating Thermostat that receives information from all communicating thermostats in a house on a central system panel. Thermostats can be reset or programmed from the central panel. In addition, the homeowner can set his/her thermostat to receive temporary messages like caller ID, weather data, and security system status.

\section{Home Energy Monitoring}

Past studies of providing instantaneous feedback on household electrical demand show promise to reduce energy consumption by $10 \%-15 \%$. Recently, such feedback devices are commercially available and dropping in price. Models typically provide a small wallor desk-mounted display that communicates the second-by-second electric power demand of the household. Most accumulate the data to show expected monthly utility costs or time related energy cost data. Some are now available for as little as $\$ 140$. More detailed (and expensive) systems can report on disaggregated end uses. More sophisticated devices allow storage of obtained data or output to a host computer to 
produce informative plots. An important recent innovation is systems which send the energy demand signal over household wiring, greatly simplifying installation.

The manufacturers mentioned below give a sampling of the products currently entering the home automation marketplace. For example, DENT Instruments, a producer of power and energy measurement instruments, recently announced the introduction of a new generation of single-channel data loggers. The SMARTlogger family of products was designed to record actual on and off transitions which gives time-of-use (TOU) information and also show total run-time in its large, five-digit LCD for many kinds of energy consuming devices. These data loggers easily monitor and analyze energy consumption data for lighting systems, motors, water heaters, fans, compressors, electric boilers, or other electrical apparatus. SMARTloggers are available in four models: Lighting, Motor, CT (Current Transformer), and Contact. All SMARTloggers use DENT's SMARTware ${ }^{\mathrm{TM}}$ software to present and analyze the collected data.

SMARTware has a variety of preprogrammed analyses and graphs, including $\mathrm{kWh}$ calculations, rate schedule graphs and summaries, load profile graphs, summary statistics and time series analysis. Data files can also be exported to popular spreadsheets and databases such as Excel and Access for additional analysis.

Watts Up Inc. sells the "Watts up?" meter which instantaneously displays the wattage being used by any device plugged into it, as well as the cost, in dollars and cents. The PRO version includes all the displays of the standard "Watts up?" and is accompanied by software that interfaces to a PC. The software automatically graphs all the data and includes an integrated analysis tool, called the Payback Calculator, which automatically calculates the time required for a new energy-efficient appliance to pay for itself. Monthly savings are calculated, and they are compared to the purchase price of the new appliance. The company also offers a Whole House Energy Monitor EUM-2000 and boasts savings up to $25 \%$ on electric bills and installation in 15 minutes or less. Its price is $\$ 200$, and it connects to a home's electric panel (120/240V) and displays the following information:

- Cost of electricity consumed in dollars and cents

- Amount of kilowatt-hours (KWh) consumed

- Projects amount of your next electric bill in dollars and cents

- Daily usage in dollars and kWh

- Instantaneous power being consumed $(\mathrm{kW})$

- Displays days, hours, and minutes monitored

- Can be used in energy conservation programs to save energy

- Can be used as a sub-meter to measure energy use of sub-panels

- Electric utilities can use it in their demand-side and energy management programs

- Units will save current information if there is a power outage.

Onset Computer Corporation manufactures a range of $\mathrm{HOBO}{ }^{\circledR}$ data loggers for residential energy monitoring - everything from when lights are on and off in a room to flexible multi-channel loggers that can monitor total electric usage of a home. Most HOBO loggers are small enough to be deployed anywhere in your home. HOBOware ${ }^{\circledR}$ 
software can be loaded on a home's PC or Mac computer and lets the homeowner view the data to see how his or her home is operating. HOBO lighting, appliance motors, and temperature and humidity monitors each range from $\$ 50-\$ 70$. Their new HOBO FlexSmart ${ }^{\mathrm{TM}}$ Logger full-house electric usage monitor runs at $\$ 300$ plus modules and sensors. HOBOware ${ }^{\circledR}$ software, priced at around $\$ 100$, is used to set-up and launch HOBO loggers and to readout data from the loggers. The software automatically plots the data for easy viewing on your PC or Mac.

The PowerCost Monitor ${ }^{\mathrm{TM}}$ is a real-time direct feedback display device for domestic energy consumers manufactured by Blue Line Innovations. The device shows homeowners, in real-time, how much electricity their home is using in dollars and cents and in $\mathrm{kWh}$. Domestic energy use studies have demonstrated that real-time feedback yields energy savings anywhere between $10 \%$ and $20 \%$. The savings at the high end of this range are realized when a tabletop energy display device, such as the PowerCost Monitor $^{\mathrm{TM}}$, is used. Its price is $\$ 159$ and leasing is an option.

UK environmental and sustainability consultancy DIY Kyoto will soon release a new product they call Wattson. A combination of energy meter and portable display, Wattson can provide real-time information about household energy consumption, displayed as both a text display of current power demand or accumulated "burn rate" of power in pounds sterling per year, and a "non-verbal" colored LED display indicating overall energy health of the house.

\section{Energy Savings Potential}

In 2001, it was estimated that $17.5 \%$ of all U.S. households had professionally installed electronic burglar alarm protection systems. Twenty eight percent of the over 1 million new homes built each year in the United States now include monitored security systems. In 1998, 13\% of new homes were built with some level of built-in intelligent controls, and it was projected that this number would increase to $26 \%$ by the end of 2005 .

With so many new homes already being built with the capability for monitoring and automation, this presents a significant opportunity for energy savings and demand control. In 1998, the average cost of installing a home security system or a home automation system ranged from $\$ 1,500-2,000$. New technologies including smaller electronic devices and cheaper data storage along with the proliferation of broadband networking in homes has made it possible to dramatically reduce the first cost of installing home automation systems that can easily be monitored both on-site and remotely.

The energy penalties associated with this topic area are related to the homeowner's lack of awareness of their own energy "footprint." Homeowners are simply unaware of the amount of energy that they are wasting from day to day. Much of the resistance to home automation systems has been complexity in understanding and operating home automation systems. In addition, many homeowners believe that saving energy requires them to give up their comfort and/or make major behavioral changes to their lifestyle. 
This is simply not the case. Educating homeowners on how to eliminate unnecessary home loads (1-watt standby electronics, auxiliary switches, setback thermostats, automatic sensors, HVAC maintenance diagnostics, etc.) would have a significant effect on residential energy consumption without inconveniencing homeowners.

Studies have shown that making consumers aware of their consumption by providing real-time display of their electricity consumption can influence behavior resulting in reductions of up to $25 \%$. Pay-as-you-go programs implemented by Woodstock Hydro (a Canadian utility) and the Salt River Project (Phoenix, AZ utility), in which customers pre-purchased electric energy at the local variety store using a smart card, resulted in energy savings of $10 \%$ to $28 \%$.

Other savings potential:

- Standby power consumption is on average between $4 \%-11 \%$ of a households' total electricity consumption that is currently not being addressed.

- A Carnegie Mellon Electricity Industry Center study concluded that setback controls could save between 5\%-8\% in electrical energy on electric water heaters.

- SWA test results indicate that cycling of the HVAC system can be reduced significantly by employing a wide deadband, and energy savings of up to $30 \%$ for space conditioning could be achieved with a wide deadband of $\forall 3 \mathrm{EF}$.

- Approximately $25 \%$ energy savings in air conditioning can be achieved by addressing cycling due to oversizing, inappropriate air flow, and improper refrigerant charge through HVAC system diagnotics.

- An Environmental Protection Agency (EPA) document on high-efficiency lighting offers a potential savings of $50 \%$ per light bulb switched to an occupancy sensor.

- Dynamic pricing programs such as real-time pricing could generate an average reduction of $4 \%$ in yearly electrical consumption and around $10 \%$ with effective feedback programs.

\section{Conclusion}

There is a lot of information and products for home automation - more than can easily be researched or presented in this report. The above mentioned products represent only a small sampling of what is available in the marketplace. New home energy monitoring devices are relatively inexpensive and easy to setup and interpret. California and other utilities have been testing demand response systems and industry alliances such as Zwave and Zigbee are being created based around home automation standards and protocols. In addition, the National Institute of Standards and Technology has been active for years in facilitating networked appliances and standards between government and industry, including internationally. It appears that home automation technology can significantly impact a home's energy use (both behavioral and physical).

Systems integration is the key element that needs to be developed for this technology to truly penetrate the market. These systems (lighting, security, HVAC control, etc.) are 
available as separate products, but few products are available that bundle these together and display the information to homeowners in an informative manner. One of the barriers has been the lack of a common communication standard for the various devices, but that is now changing.

Wireless technology and the emergence of national standards for wireless networking communications protocols (Zwave and ZigBee), are now making it possible to easily incorporate customized home energy monitoring and automation solutions to new and existing homes alike. With the elimination of the needs for wiring and the wider availability of a variety of sensors and monitors that "speak" the same language, homeowners will have more flexibility than ever to develop customized solutions to their energy monitoring and controls. Better yet, these systems will be both scalable and modular, allowing for homeowners to make changes to the system in response to the changing needs of the household over time.

Research should be focused on integrating the following technologies into a single package that is user-friendly for homeowners:

- Reduce miscellaneous electrical loads by providing direct, real-time feedback on their home electrical use (whole-house and individual loads) and electricity costs

- Reduce cooling and heating energy use through enhanced management of thermostat settings

- Reduce lighting energy use through enhanced management of lighting levels

- Reduce standby electrical loads through scheduled control of select electrical outlets within the home.

\section{References}

"Consumer Strategies for Controlling Electric Water Heaters under Dynamic Pricing." Chong Honck, K.Goh, and Jay Apt. Carnegie Mellon Electricity Industry Center Working Paper CEIC-04-02.

Darby, S. 2000. "Making it obvious: designing feedback into energy consumption." Proceedings, 2nd International Conference on Energy Efficiency in Household Appliances and Lighting. Italian Association of Energy Economists/ EC-SAVE programme.

Farhar, Barbara 1989. "Effects of Feedback on Residential Electricity Consumption: A Literature Review.” Solar Energy Research Institute.

Gram-Hanssen K., E. Gudbjerg "Reducing Standby Consumption in Households: By Means of Communication or Technology?". Proceedings from the 2006 ACEEE Summer Study on Energy Efficiency in Buildings. 7:73-84.

Holmstrom, David; "House with and IQ", Christian Science Monitor, November 17,1998 . 
"How Much Energy Are We Using? Potential of Residential Energy Demand Feedback Devices", Florida Solar Energy Center and LBNL.

Roth Garry, “A Successful 14 Year Experiment”, Home Energy Magazine, January/February 2004.

Stein, Lynn F. 2004. "Final Report: California Display Pilot Technology Assessment”.

Unger, Jason. "Structured Wiring to Be in 61\% of 2005 Homes." TecHome Builder. May/June 2005:10.

\section{Best Practices for Reducing Air Leakage Through Recessed Can Lights Research}

Industry stakeholders recommended that DOE perform further RD\&D on, and deployment of, the best practices on sealing up and insulating recessed can lights or sealed recessed can lights themselves (can lights are typically recessed into the ceiling penetrating into an attic or other building cavity and need to be sealed and insulated). When can light fixtures are not properly sealed, these lights are the source of significant infiltration and exfiltration through the building envelope, resulting in energy losses in both heating and cooling seasons. Sealing of can lights may create a possible fire hazard if done incorrectly. Can lights rated for insulation contact (IC rated) are often specified in energy-efficient homes so that insulation can be installed to cover the fixtures from the attic. However, not all IC rated lights are airtight so builders and homeowners are often confused on this matter.

Blower door testing, done in conjunction with infrared imaging, has revealed that out of all the possible air leakage sites in some homes, can lights are responsible for the worst leakage. It is estimated that one conventional (IC or non- IC) fixture can be responsible for the loss of between $\$ 5$ and \$30 per year worth of energy (Mechanical Engineering Department at Penn State University in conjunction with Juno Lighting Inc.)

Early fixtures (Non- IC fixtures are designed for non-insulated ceilings), because of the heat build-up from the bulbs, had to be left exposed in the attic with a minimum six-inch uninsulated space around them. Subsequently, the electrical industry produced fixtures that had a tin box installed over the ballast, which enabled them to be insulated with electrical code approval. IC fixtures may be in contact with insulation. IC-rated lights are typically "double can" fixtures, with one can inside another. The outer can (in contact with insulation) is tested to make sure it remains cool enough to avoid a fire hazard. However, these boxes on newer fixtures are still unsealed in that the ballast box is vented. Some electrical contractors will claim they are sealed, when indeed they are not. Recessed light fixtures must be sealed. They should also be insulated, but only when protected by a large enough wood or drywall box to prevent overheating. Even a newer fixture with its tin box will require a wood or drywall box over the top of the tin box to allow heat from the bulb to dissipate. 


\section{On-Site Sealing}

A site-built sealed box around the fixture (with required minimum clearances of at least 3 inches), made of drywall or other approved material, is one way to eliminate air leakage. All wiring penetrations and the joint between the box and ceiling drywall must be sealed too. It is important to note that it may be difficult or impossible to build a box that maintains minimum clearances due to the proximity of the light fixture to ceiling joists or other structural components. It is also labor-intensive to custom build these boxes and may not be cost effective depending on the number and accessibility of fixtures to the covered and the actual measured leakage rates.

Retrofit kits which convert existing recessed can lights to compact fluorescent fixtures are also available. Some of these conversion kits, such as TCP's Recessed Retrofit Kit, though not designed specifically to be airtight, result in substantially reduced air leakage rates when installed in traditional fixtures.

Code requires full insulation coverage over recessed lighting. There is an exception however: if the total area of all recessed lighting is less than one percent of the total ceiling area, R-10 insulation is permitted over the fixtures.

\section{Airtight Fixtures}

Some recessed cans themselves are rated airtight, while others use gaskets and trims to convert a standard fixture into an airtight fixture (these cans are sometimes labeled "airtight ready".) Most major lighting manufacturers have made a number of different types of housing and trim packages available, sold under trademark names such as Airtite, Air-Loc, and Air Seal.

\section{Cost}

A conventional IC rated housing and trim package (each sold separately) runs around $\$ 25$. Contractor prices for airtight fixtures on the other hand range from $\$ 30$ to over $\$ 60$, depending on the manufacturer. This does not include installation cost. According to Charles Huber, vice president of corporate development at Juno Lighting, Inc., the extra cost to the consumer for Juno's Air-Loc lighting fixtures compared to non-airtight fixtures, is about $\$ 5$. At that premium, the payback period from energy savings is one year or less. As an example, on www.elights.com, the Halo housing 7-inch IC (H7ICT) and non-IC (H7T) rated had the same price of \$12. The air-tight version (H7ICAT) sells for $\$ 15$ and a cost premium of $\$ 3$ or $25 \%$. Further research indicates that air-tight can lighting and trim kits can come with premiums as high as $75 \%$. These premiums are still not bad compared to the labor and material costs to construct an air-tight box around can light fixtures.

\section{Codes and Standards}

A thermal overload or "cutout" switch has been required since 1982 on all manufactured recessed can light fixtures. Measured air leakage rates for conventional fixtures vary 
from less than $10 \mathrm{cfm}$ to over $30 \mathrm{cfm}$ at 75 Pascals. Many manufacturers now refer to their own products that meet the 1992 air tightness criteria as Washington State compliant. To qualify under the 1992 code change, fixtures had to restrict measured air leakage to less than $2 \mathrm{cfm}$ air flow at 75 Pascals pressure difference (tested according to ASTM E-283 test method).

With regards to recessed lighting fixtures, section 502.1.3 of the International Energy Conservation Code (IECC) specifies prescriptive design and installation criteria for recessed lighting as one of the following:

1. Type IC rated, manufactured with no penetrations between the inside of the recessed fixture and ceiling cavity and sealed or gasketed to prevent air leakage into the unconditioned space.

2. Type IC or non-IC rated, installed inside a sealed box constructed from a minimum 0.5 inch-thick gypsum wall board or constructed from a preformed polymeric vapor barrier, or other airtight assembly manufactured for this purpose, while maintaining proper clearances of not less than 0.5 inch from combustible material and not less than 3 inches from insulation material.

Building energy codes in a majority of the states now require recessed cans installed in the building shell to be airtight (reference test procedure ASTM E-283). All states that have adopted the 1995 Model Energy Code (MEC), or the 1998 or 2000 International Energy Conservation Code (IECC), have this requirement on their codebooks. To date, 33 states representing more than $67 \%$ of the U.S. population have adopted such codes. IC-rated Washington State Compliant airtight fixtures are now required by chapter 11 of the International Residential Code IRC 2003. Due to the big difference in cost, there is an alternative allowed by the code. A builder may opt to fabricate a sealed box of 0.5 inch gypsum board to completely encapsulate the fixture and seal it to the back side of the ceiling wallboard, while maintaining a required clearance of 3 inches from the fixture (IRC 2003 Section N1102.1.11).

\section{Current Research and Test Results}

To encourage lighting fixture manufacturers to develop and offer high-efficiency recessed cans that perform well in an insulated ceiling environment, DOE is sponsoring the Recessed Downlights Project, which is managed by Pacific Northwest National Laboratory (PNNL). The project tests and promotes fixtures with the following features:

- Pin-based CFLs rated for 10,000 hours of life

- Airtight housing to prevent air leakage into unconditioned spaces (attics)

- IC-rated for direct contact with insulation

- Electronic ballasts for quiet, flicker-free operation

- Fixture efficiency of at least 50\%, meaning at least $50 \%$ of the lamp's total light output is projected out of the fixture as useful illumination

- Minimum light output of 900 initial lumens, net of fixture losses (to approximate the sustained light output of a 65-watt reflector lamp, even accounting for lumen depreciation over the lifetime of the CFL). 
The results of field testing performed showed that following the code (for non-IC rated) to seal the leaks sometimes produced safety problems. PNNL's suggestions were:

- Use only PAR bulbs or CFLs.

- Do not use any bulb that exceeds 75 watts.

- Make sure the airtight drywall boxes maintain a minimum of 3 inches of clearance to all parts of the fixture, including the terminal or junction box.

- Do not place insulation over the top of the drywall enclosure.

The Kitchen Lighting System (KLS), developed at the California Lighting Technology Center (CLTC) with funding from the California Energy Commission's (CEC) Public Interest Energy Research (PIRG), features two CFLs that can be controlled from a single ballast, uses fixtures that emit more than 50 lumens per watt, and costs less than half as much to install as current commercial grade products.

New products in development include LED downlights, which offer energy benefits in the form of reduced wattage per lumen output and longer lamp life. However, these fixtures are more sensitive to high temperature conditions than incandescent and fluorescent fixtures. As LED technology is developed, this issue will need to be addressed to allow for air tight conditions and insulation contact if these fixtures are to be marketed as energy efficient alternatives.

\section{Energy Savings Potential}

The energy savings potential for improving air leakage performance of existing recessed can lights will vary greatly from house to house depending on the number, location, and type of fixtures installed in the home. Estimated leakage rates of 10-30 cfm, 75 roughly translate to $8-23 \mathrm{cfm} 50$ per fixture. For a home with 10 or more fixtures, this can represent $10 \%$ or more of the total air leakage through the envelope as measured using a blower door. Based on typical air sealing results, it is estimated that sealing of recessed can lighting may further reduce the heating and cooling energy loads on a home by an additional $5 \%-10 \%$.

\section{Conclusion}

More research could be done on the price difference between buying an airtight can lighting system and paying a contractor to make it compliant to the existing code. Alternative products and techniques are needed to allow for less labor-intensive sealing of existing cans. Air tight conversion kits that can easily be installed in existing can lights without the need for an electrician hold the most promise as they address two issues at once, reducing the wattage draw by converting to compact fluorescent lamps and limiting air leakage. However, given the wide range of fixture types and sizes currently available in the marketplace, it would be difficult to manufacture retrofit kits to address all possible existing fixtures. Additional research into safe, cost-effective ways to seal existing can lights without replacement or on-site manufacture of sheetrock boxes is needed. 


\section{References}

"Air and Moisture Leakage Through Recessed Ceiling Light Fixtures", Energy Design Update, January 1994

Armanda Larry, "Further Wrestling with Recessed Can Lights", Home Energy Magazine, September/October 2005

Armanda Larry, "Recessed Can Lights a Breeze", Home Energy Magazine, July/August 2001

Armanda Larry and Steve McCarthy, "A Recessed Can of Worms", Home Energy Magazine, January/February 2001

Brons Jennifer, "Creative Uses of Fluorescent Lighting", Home Energy Magazine, September/October 2004

"Cheaper, Easier CFL Downlighting", California Energy Commission PIER technical Brief, May/June 2006

Gordon Kelly and Jeff McCullough “Recessed Downlights”, Builder News Magazine

Gordon Kelly and Jeff McCullough, "Recessed Lighting in the Limelight", Home Energy Magazine, January/February 2004

Gunshinan Jim, “A Better Way to Light a Kitchen”, Home Energy Magazine, July/August 2002

Holbrook Dave, "Shopping for Recessed Lights", The Journal of Light Construction International Residential Code 2003 Chapter 11

International Energy Conservation Code 2000

International Energy Code Chapter 5

"LED Application Series: Recessed Downlights", U.S. Department of Energy, EERE Building Technologies Program, PNNL-SA-52145, November 2006

Model Energy Code 1995

National Electrical Code, 2002 Edition

The Pennsylvania Housing Research/Resource Center, Air Leakage in Recessed Lighting Uniform Construction Code (UCC) chapter 11 (section N1101.3.2.2) 
Van der Meer Bill, “Air Leakage Control: The Devil's in the Details”, Home Energy Magazine, January/February 2005

Zerodraft House Doctor

\section{Energy-Efficient Dehumidifiers (Stand Alone and Whole-Building) Research}

As more attention is being paid to moisture in basements and crawlspaces as well as mold in homes, stand-alone dehumidifiers are seen as part of the solution. In addition, central dehumidifiers are being introduced to the marketplace targeted at hot humid climates to "wring" out the air without over-cooling the house. Today's dehumidification equipment is, for the most part, quite energy-intensive. With the advent of increased dehumidification equipment purchases, industry stakeholders are recommending that DOE research and develop more efficient technology.

Dehumidifiers come in two forms: free-standing or ducted (often integrated into a home's central air-conditioning distribution system.) Dehumidifier capacity is usually measured in pints per 24 hours. The optimum relative humidity $(\mathrm{RH})$ level for a building is generally considered to be between $30 \%$ and $50 \%$. Anything above this range may promote mold growth. Many dehumidifiers include a built-in humidistat, a device that allows the user to set the desired RH level for the space being conditioned. Once the room reaches the desired $\mathrm{RH}$ level, the dehumidifier will cycle off automatically. The energy efficiency of dehumidifiers is measured by an energy factor in liters of water removed per kilowatt-hour $(\mathrm{kWh})$ of energy consumed or $\mathrm{L} / \mathrm{kWh}$. A higher energy factor means a more efficient dehumidifier.

Fans and dehumidifiers use less energy than air conditioners and can help to make the home more comfortable during the warm months (National Association of Home Builders [NAHB] Research Center 2004), but dehumidifiers consume as much electricity as the average refrigerator and cost U.S. consumers approximately one billion dollars a year in utility bills (ENERGY STAR® 2004). In addition, dehumidifiers generate heat when they are running which is typically released into the space around the appliance. Since use of dehumidifiers most commonly occurs during cooling season, the simultaneous use of dehumidifiers and air conditioners in the same space is possible, resulting in one system fighting the other to maintain acceptable comfort levels in the home.

\section{Current Products and Costs}

Many companies manufacture stand-alone and central dehumidifiers and many are ENERGY STAR rated. As an example, AprilAire sells central, whole-house, air conditioning integrated dehumidifiers. They have two models the 1700 (90 pints/day) which is ENERGY STAR rated and the 1720 (150 pints/day). Using the following assumptions of normal indoor air conditions (indoor temperature of $75^{\circ} \mathrm{F}$, indoor $\mathrm{RH}$ of $55 \%$, and air flow of $275 \mathrm{CFM}$ ), the Model 1700 power consumption is $825 \mathrm{~W}$. At an electricity rate of $\$ 0.09 / \mathrm{kWh}$, the cost of operation is almost $\$ 2$ per day. The 1700 
model's price is around $\$ 1,200$ to $\$ 1,500$, depending on discounts. In addition, since a central dehumidifier relies on the air handler fan to distribute conditioned air throughout the house, this adds an additional electrical load which is not accounted for in the dehumidifier manufacturer's energy consumption data. Based on research conducted by Steve Winter Associates, inefficient air handler fans consumed as much as 700 watts. If a central dehumidification system is installed with an air handler that has an inefficient blower, the actual operating costs of this system could increase by as much as a factor of 2.

Most stand-alone dehumidifiers cost between $\$ 100$ and $\$ 500$. Generally speaking, the higher the capacity of the dehumidifier, the higher the energy efficiency so it is recommended that homeowners use one adequately sized unit instead of purchasing more than one smaller unit and running them simultaneously.

\section{Current Research and Test Results}

Dehumidifier tests shall be conducted in accordance with Clauses 4, 5, and 7 of ANSI/AHAM (American National Standards Institute/Association of Home Appliance Manufacturers) Standard DH-1, except that a watt-hour meter shall be used to measure dehumidifier energy consumption during the capacity rating test. The watt-hour meter shall be accurate within $0.5 \%$ of the indicated value and have a scale with graduations of 1 watt-hour or less. Energy Factor is to be calculated according to Section 4.2 of Canadian Standard CAN/CSA-C749-94.

In addition, DOE is currently sponsoring a project to develop an integrated heating, ventilation, cooling, and dehumidification system for residences, conducted by Davis Energy Group. Inadequate fresh air ventilation and poor indoor humidity control are two of the biggest problems in residential buildings. Both leaky older homes and more energy efficient newer homes often have problems maintaining adequate indoor comfort and air quality. Conventional air conditioning systems are not capable of providing the proper balance of cooling and dehumidification under varying outdoor conditions, and stand-alone dehumidifiers reduce overall system efficiency. This project will develop a cost-effective package of refrigeration components and controls that will provide the capability to meet changing latent and sensible loads, and provide fresh air ventilation, while using less energy than air conditioners with stand-alone dehumidifiers.

The integrated system should be well suited for controlling indoor temperature and relative humidity, along with providing fresh air ventilation, in single-family and small commercial applications located in humid regions. Since over three-quarters of the U.S. population is located in climates with high humidity, the market is substantial. Preliminary energy savings estimates suggest that the proposed system can provide improved comfort while saving $20 \%$ (650 kWh/year) of typical cooling and dehumidification energy usage, resulting in potential cumulative national energy savings of $162.5 \mathrm{GWH}$ per year. In addition, the system should reduce the potential for mold growth, thereby reducing insurance claims. 


\section{ENERGY STAR Labeled Dehumidifiers}

The following webpage lists all the ENERGY STAR labeled dehumidifiers:

www.energystar.gov/ia/products/prod_lists/dehumid_prod_list.pdf\#search='dehumidifier'

There are 15 different manufacturers and numerous models. Qualifying models remove the same amount of moisture as standard models, but use $10 \%$ to $23 \%$ less energy. To become an ENERGY STAR labeled dehumidifier, equipment must meet the following qualification criteria:

\begin{tabular}{|c|c|}
\hline \multicolumn{2}{|c|}{ Table 1: Criteria for ENERGY STAR Qualified Standard Capacity Dehumidifiers } \\
\hline $\begin{array}{c}\text { Product Capacity } \\
\text { (L/day) }\end{array}$ & $\begin{array}{c}\text { Energy Factor Under Test Conditions } \\
\text { (L/kWh) }\end{array}$ \\
\hline $\mathrm{L} /$ day $<10$ & $\geq 1.20$ \\
\hline $10 \leq \mathrm{L} /$ day $<25$ & $\geq 1.30$ \\
\hline $25 \leq \mathrm{L} /$ day $\leq 35$ & $\geq 1.50$ \\
\hline
\end{tabular}

\begin{tabular}{|c|c|}
\hline \multicolumn{2}{|c|}{ Table 2: Criteria for ENERGY STAR Qualified High Capacity Dehumidifiers } \\
\hline $\begin{array}{c}\text { Product Capacity } \\
\text { (L/day) }\end{array}$ & Energy Factor Under Test Conditions \\
(L/kWh)
\end{tabular}

Some non-ENERGY STAR rated products have an energy-saver setting, such as the Bionaire BDQ24.

In 2004, a new dual-service residential integrated water heater/dehumidifier (WHD) was being designed, fabricated, and tested. The prototype was designed to meet ENERGY STAR performance standards. This dual service appliance, the integrated water heater/dehumidifier (WHD), is potentially a low-cost solution for both efficient electric water heating and dehumidification.

\section{Energy Savings Potential}

Due to the variability in conditions related to climate, site water management, building construction, and mechanical systems, it is difficult to predict an average, or even typical, energy savings estimate to associate to improved dehumidifier technology. However, the following example is provided to illustrate one scenario where dehumidification is contributing as much as $50 \%$ to the home's total electrical baseload for a given month.

In a Building America study currently in progress conducted by Steven Winter Associates to monitor electrical baseloads, one home located in Wisconsin exhibited unusual peaks in electrical usage starting in the end of April 2007. It was determined, based on simultaneous monitoring of relative humidity levels and electrical consumption 
that the homeowners were running a dehumidifier which was drawing approximately 600 watts. On-going monitoring with baseload disaggregation by end use for the month of May indicates that the dehumidifier is contributing $450 \mathrm{kWh}$ of electricity consumption to a total baseload of $909 \mathrm{kWh}$, or $50 \%$ of the total baseload for the month. It is not unreasonable to assume that in a climate with more severe humidity conditions, such as the Southeast in the summer that the dehumidification electricity load would be even greater.

Given that dehumidifiers run on the same type of refrigerant cycle as refrigerators or room air conditioners, their electrical consumption is also similar. When combined with other side effects like increased use of air handler fans for circulation on central systems and the release of waste heat into the home, dehumidifiers can represent a significant portion of a home's overall energy consumption. Based on past experience with refrigerators and room air conditioners, it may be possible for dehumidifier manufacturers to improve overall efficiency during operation by $10 \%-20 \%$. However, by combining more efficient appliances with more effective moisture management strategies, homeowners may be able to save much more on their monthly electric bill, perhaps as much as $50 \%$.

\section{Conclusion}

Although new variable-speed, central air-conditioning systems can dehumidify a house without much overcooling, DOE should still invest in researching and develop more efficient dehumidification technology, both stand-alone and central systems. However, based on the above research, the problem does not entirely lie in the dehumidifier's energy-efficiency (especially since consumers have a wide range of ENERGY STAR rated products available), but more in under-sizing and source control. It has been shown that operating, for example, two 50-pint units has a much higher net present cost than operating a single 100-pint unit.

Although improved technologies may help in reducing the electrical consumption of these devices, the real solution is better building practices to eliminate the problem at the source. By managing moisture entering the home better, the need for dehumidification can be greatly reduced and perhaps even eliminated. In addition to research targeting improved energy performance of dehumidifying appliances, research is also needed to increase awareness of moisture issues in buildings including improved diagnostic and remediation techniques, particularly for existing homes. Remediation of moisture issues in homes incorporates a wide range of possible products and applications including better site drainage and rain-water runoff systems; moisture-proofing of foundation floors and walls; proper insulation and air sealing techniques to keep moisture from entering walls, attics, and other interstitial spaces; use of "smart" vapor barriers and other building products, and proper applications for ventilation of basements and crawlspaces. 


\section{References}

Air-Conditioning \& Refrigeration Institute (ARI)

Aldrich, R. and Vijaykumar, G. "Ventilating Small Chicago Homes," Home Energy Magazine, Jan/Feb 2006

Assessing Consumer Values and the Supply-Chain Market for the Integrated Water Heater/Dehumidifier, October 2004, ORNL/TM-2004/159

American Society of Heating, Refrigerating and Air-Conditioning Engineers (ASHRAE)

Gas Appliance Manufacturers Association (GAMA)

Association of Home Appliance Manufacturers (AHAM), www.aham.org

www.energystar.gov

www.consumersearch.com

\section{Energy-Efficient Furnace and Air-Handling Cabinets Research}

Residential furnaces and air-handling cabinets are notorious for leaking air or, more specifically, conditioned air. Industry stakeholders recommend that DOE work with manufacturers to research and develop cabinets with near zero air leakage. In addition, there are opportunities to improve the energy performance of furnace and air conditioning air handlers through improved fan blade design, more efficient motors, and the design of the housing around the fan.

\section{Current Technology and Cost}

The function of a furnace or air-handling cabinet is to contain the heated or cooled air, furnish protection for the controls and other components inside the furnace, ensure owner safety by isolating hot and moving internal parts, and to provide a pleasing, easy-tomaintain appearance.

New construction codes (IECC and IRC) call for sealed air handlers, but no specifications are provided. DOE has submitted a code change proposal to change this. Most manufacturers use 22-gauge steel to produce their cabinets, though some thinner metals are found in some brands. Typically, the furnace and cabinet panels are joined together with multiple penetrating screws. Increasingly many manufacturers are using pre-painted steel in their cabinets which means the steel comes to them already painted prior to being punched, notched, and bent. Sheared or punched edges on pre-painted steel result in exposed, unpainted steel which, in turn, can lead to future corrosion. 
As an example of typical cabinet manufacturing, Thermo Pride uses 22 gauge steel in all external cabinet panels but thicker 13 gauge or 16 gauge metals in the furnace bases, support panels (such as the blower deck), and for some brackets. For over forty years, Thermo Pride cabinet side panels have been fabricated with interlocking joints. This interlocking design provides tight air seals, greatly reduced potential for rattles, plus it substantially strengthens the furnace with the use of minimal screws. The inside surface of exterior cabinet panels adjacent to the furnace heat exchanger are covered with $1 / 2$-inch thick, nylon reinforced foil faced fiber glass insulation to retain maximum heat for distribution into the duct system.

\section{Fan Power Demand}

This section talks about how different system inefficiencies (not limited to ducts) raise fan power demand. This section is excerpted from an ACEEE paper authored by Proctor, J. and Parker, D. entitled Hidden Power Drains: Residential Heating and Cooling Fan Power Demand, 2000.

Field tests show that air handler devices do not meet basic performance standards and that the interactions between components combine to further degrade overall system efficiency. The findings support conclusions from previous research in Canada that called for a systems approach to improving air handler efficiency. This study reports that fan power consumption in U.S. air conditioners is about $40 \%$ higher than estimates used in the DOE Central AC and Heat Pump Test Procedure when rating air conditioners. Fan power draws approach 1000 watts, similar to adding a 1000 watt electric resistance heater in the air stream. The low assumed watt draw masks the need for continued improvements in equipment performance and creates operating cost penalties - not advantages - for customers. Application of high-efficiency filters without attention to static pressure considerations would exacerbate these effects by raising air horsepower and watt draw.

Air handler flow rates on furnaces have increased about $25 \%$ in recent years. This is in spite of a general reduction in installed furnace size. This increase in flow produces higher efficiency furnaces (when efficiency is measured as heat output per heating fuel input) but duct systems have not been modified to allow for the higher flows. The resulting inadequacy of duct design causes an increase in external static pressure that adversely influences fan energy use, air flow, and total system performance. Air conditioner and heat pump efficiencies have also risen substantially in recent years. The watt draw of the compressor has been substantially reduced on these machines, so that the air handler fan watt draw has become a larger part of the total watt draw. At the same time, more effective air filtration is being added to air handlers.

The proposed ASHRAE Standard 62.2P, Ventilation and Acceptable Indoor Air Quality in Low-Rise Residential Buildings, if adopted, will further the use of more effective filtration devices. These devices could increase external static pressure beyond current levels that already exceed Department of Energy AC and Heat Pump Test Procedure default values. Fan watt draw, easily $17 \%$ of the total residential air conditioner energy 
consumption, will become a greater contributor to overall unit energy use, secretly degrading air conditioner efficiency. Beyond inadequate duct sizing, air movement through space conditioning systems is compromised by the non-aerodynamic intake and exit conditions common in cabinet and heat exchanger designs. It is worth noting here that fan watt draws increase approximately as the cube of the air flow (for a constant restriction to air flow).

The measurements of fan power consumption, external static pressure, and air flow reported here also show that the DOE test specifications used in calculating air handler performance efficiencies misrepresent the actual conditions under which the equipment operates.

An implication suggested by the findings of the Proctor and Parker study is that duct distribution systems should be more adequately sized. While the authors champion this goal, reality shows that most residential duct systems are being undersized using duct slide rules with an arbitrary $0.1 \mathrm{IWC} / 100 \mathrm{ft}$. input for duct selection without regard for available static pressure, actual duct length, or fittings. While this is not the approved method for sizing, it is the most common method. Preaching improved duct design is important but air moving systems, which meet current and realistic circumstances, are definitely needed.

\section{Energy Savings Potential}

Air handlers are often a major source of air leakage in a home's forced air distribution system. The highest and lowest pressures occur on each side of the air handler. The Florida Solar Energy Center conducted leak testing on 69 air handlers in new Florida houses. Using the operating pressures in the air handler and at the plenum connections, the measured Q25 results converted to actual air leakage of $58.8 \mathrm{cfm}$ on the return side (negative pressure side) and $9.3 \mathrm{cfm}$ on the supply side (positive pressure side). The combined return and supply air leakage in the air handler and adjacent connections represented $5.3 \%$ of the system air flow $(4.6 \%$ on the return side and $0.7 \%$ on the supply side). A $4.6 \%$ return leak from a hot attic (peak conditions: $120^{\circ} \mathrm{F}$ and $30 \% \mathrm{RH}$ ) can produce a $16 \%$ reduction in cooling output and $20 \%$ increase in cooling energy use.

In addition to the energy penalty, leaky air handlers can also pose a health risk and moisture damage. Air handlers are often located outside of the conditioned space (garages, attics, crawlspaces and basements). Significant return side leakage can directly draw into the home car exhaust fumes, mold spores, pollen, and other contaminants. This leakage can also cause pressure imbalance, more specifically, a pressurized living space which can force moisture laden air into cold envelope cavities in a cold climate home.

With proper design and installation, energy losses attributable to leakage around the cabinet should be reduced to near zero. Additional energy savings are possible with improvements to other air-handler components, in particular the motor and fan design. 


\section{Conclusion}

No evidence was identified through this limited Internet research on manufacturers working to improve their HVAC cabinet designs; although, this information is not likely to be advertised on their websites until products are commercialized. Possible improvements to the existing technology include changing the cabinet design from removable panels to gasketed doors for maintenance and filter slot designs that can be installed, removed, and reinstalled easily and tightly.

\section{References}

"Air Handlers: An Appliance of Airtight Defiance?," Charles Withers and James Cummings, ACEEE Summer Study 2006, FSEC-CR-1660-06.

DOE Code Change Proposal. Ronald Majette. March 23, 2006

www.newenglandoilcompany.com

\section{HVAC Fault Detection Research}

Incorrect refrigerant charging of central air-conditioning and heat pump units can lower system efficiencies up to $30 \%$ and, besides having an HVAC contractor check it, there is currently no means for homeowners to know if their HVAC system refrigerant levels are low. Diagnostic tools improve equipment performance by signaling the need for preventive maintenance or repairs, and monitoring tools allow real-time control of energy loads. Accordingly, industry stakeholders suggest DOE help develop a residential HVAC refrigerant charging level indicator, which could whistle, ring, beep, light up, or somehow alert homeowners of a problem.

Faulty operation of HVAC systems including air-conditioners and heat pumps in residential buildings is prevalent and results in increased energy use. Common faults are incorrect refrigerant charge, incorrect airflow, evaporator fouling (dirty indoor air-filter), and condenser fouling (dirty outdoor coil). Levins and Rice [1] found in three case studies for residential buildings in California that refrigerant charge was improper in more than $50 \%$ of the HVAC systems. According to Proctor [2], tests of more than 4000 residential air-conditioning systems in California demonstrate that many systems have incorrect refrigerant charge levels. The test results show that about $34 \%$ are undercharged and $28 \%$ are overcharged. Correct refrigerant charge is very important for proper operation of an air-conditioner. Overcharged refrigerant can cause floodback, slugging, and compressor failure. Undercharge will prevent adequate cooling. Both conditions reduce energy efficiency, especially the undercharge condition. The issue of refrigerant leakage and recharging is not fully explored in the current systems that utilize refrigerant mixtures such as $\mathrm{R}-410 \mathrm{~A}$ and $\mathrm{R}-407 \mathrm{C}$. If there is a leak in a system with a refrigerant mixture, there is no guarantee that the refrigerant composition is not altered. Simply adding additional refrigerant to such a system may not yield the required composition. The system may need to be evacuated and recharged with the refrigerant mixture. 
If air flow is too high, room air can't be dehumidified properly. On the other hand, if air flow is too low (could be due to dirty air-filter), the room cannot be cooled properly. Also, very low air flows can freeze the indoor coils. Neme, et al. [3] reviewed 12 different studies of air flow. Every one of those studies found significant air-flow problems. Seven studies that had sufficient data suggested that $70 \%$ of all homes had airflow $20 \%$ below the recommended levels.

\section{Current Technology and Cost}

Traditionally, there are three types of refrigerant leak detecting technologies: corona discharge, heated diode, and ultraviolet (UV). Corona discharge method uses an electric current to detect leaks. Anytime something crosses and breaks the current it sounds an alarm, thus detecting the leak. This technology is relatively inexpensive and can be reliable depending on the conditions under which it is used. The price to the end user for this technology is usually in the $\$ 150$ to $\$ 200$ range (in 2002 dollars). The drawback to this technology is that it can give false readings.

Heated diode technology is more refrigerant sensitive. This technology uses a sensor that is looking for a specific type of component of refrigerant to set off an alarm. A pump is required to draw in the substance and because it is controlled by heat there is a certain amount of time required for warm-up. Among advantages of this technology, it is more accurate and more refrigerant specific. Among its disadvantages, the user level cost ranges from $\$ 450$ to $\$ 500$, and there is additional time required for warm-up.

The ultraviolet light method for detecting leaks requires a special lamp designed for using ultraviolet or black light to look for an oil-based dye that is highly active when the light shines on the dye. The dye is a compressor oil-based dye that is injected into an air conditioning system and circulated through the system via operation. If a leak is present, the dye will mist through at that point. Among advantages of this type of leak detection are even hard-to-find leaks will be noticeable and the dependability is better (there is no highly sophisticated technology to break down). Among disadvantages, injecting the dye can be sloppy and create false leak impressions, and not all the original equipment manufacturers (OEMs) have approved the leak-detecting dyes for use with their components. The user price will vary from $\$ 300$ to $\$ 400$, depending on the type of kit purchased. Replacement dyes must also be purchased as needed because they are a disposable item.

The aforementioned technologies, however, are used only when the users of equipment already know a leak has developed. There is no warning in the early stage of leaks.

There are numerous refrigerant charge gauges on the market, but most of them are geared towards HVAC contractors. No HVAC system-integrated refrigerant level indicators were identified.

Honeywell's HVAC Service Assistant [4] is one of the currently available products on the market for detecting HVAC faults in the field. This is a valuable tool for field technicians when there is already a reported problem. This is a hand-held device that can 
detect refrigerant charge fault in addition to common faults such as airflow fault, liquid line obstruction and condenser fouling fault. However, this device is not for on-board continuous monitoring of HVAC systems. Invisible Service Technician [5] is an onboard diagnostic product for residential and light commercial applications that is currently available on the market. This device incorporates multiple temperature sensors, differential pressure sensors, and condensate drain sensor to detect abnormalities. This device is equipped with a communication feature to dial a service contractor if an abnormality is encountered and detected. This device doesn't identify refrigerant charge level or fault level.

Another field diagnostic system/service that has been in use is CheckMe [6] from Proctor Engineering. This system is also for assisting technicians in detecting airflow fault and refrigerant fault in the field.

A team comprising Purdue University, Field Diagnostics, Inc. and Honeywell have developed an automated fault detection and diagnosis system for roof-top air-conditioners [7]. This device utilizes only temperature sensors to detect refrigerant charge fault, evaporator fouling fault, compressor valve leakage fault, condenser fouling and liquidline restriction fault. This device has been demonstrated in field tests in California and this technology is expected to be commercialized by Honeywell.

Oak Ridge National Laboratory [8] developed prototype concepts for refrigerant charge and dirty air-filter fault detection. These faults are detected by temperature sensors only.

Steven Winter Associates, Inc. has been working on the development of a device that integrates temperature and humidity control with fault detection of residential air conditioners under a USDOE SBIR project. Home Automation is a subcontractor who will be marketing the technology. The device incorporates only a few temperature sensors and one relative humidity sensor to control temperature and humidity, and to detect: refrigerant over charge, undercharge, and airflow faults. The prototype device is currently being tested in the laboratory.

\section{New Technologies}

DOE, through Oak Ridge National Laboratory (ORNL), is developing a low-cost, nonintrusive (on-board) refrigerant charge indicator sensor that measures the charge of working fluid on vapor compressors, alerting homeowners of the need for recharging. The sensor, based on temperature measurements, will be inexpensive and easy to incorporate into existing heat pumps and air conditioners. The refrigerant charge indicator is based on the fact that when refrigerant starts to leak, the evaporator coil temperature starts to drop and the level of liquid subcooling drops. When the coil temperature or liquid subcooling drops below a preset reading, a signal, such as a yellow warning light, can be activated to warn the equipment user that the system is undercharged. A further drop of coil temperature or liquid subcooling below another preset reading would trigger a second warning signal, such as a red warning light, to warn 
the equipment user that the unit now detects a leak and immediate action should be taken. The warning light cannot be turned off until it is re-set by a refrigeration repairman.

A traditional refrigerant charge indicator requires intrusion into the system to measure the refrigerant high-side and low-side pressures. Once the pressures are known, based on the equipment's refrigerant charging chart or, in most cases, based on the technician's experience, the refrigerant charging status is determined. However, there is a catch. By the time a refrigeration technician is called, most of the refrigerant has already escaped into the atmosphere. The new technology provides a real-time warning so that when, say, $20 \%$ of the refrigerant has leaked, the equipment users will be warned, even though the equipment is still functioning properly at rated capacity. Temperature sensors are becoming very accurate and very low in cost, compared with pressure sensors. Using temperature sensors to detect refrigerant charge status is inherently non-intrusive, inexpensive, and accurate.

Heat pumps are the initial target application. Other potential residential applications include heat pump water heaters and small residential heating and cooling equipment. Other current developments are the coefficient of performance (COP) meter, an on-board or hand-held device that assesses heating and cooling equipment efficiency by measuring charge, air flow, and temperature.

\section{Energy Savings Potential}

Both undercharge and overcharge can reduce cooling equipment longevity, capacity, and efficiency.

According to laboratory testing [9], capacity is reduced by $34 \%$ and $10 \%$ for fixed orifice and TXV systems, respectively for an undercharge of $30 \%$. For the same case, EER is reduced by $32 \%$ and $8 \%$, respectively for fixed orifice and TXV systems with R-410A.

When the system is overcharged by $20 \%$, EER is reduced by $2 \%$ and $4 \%$ respectively for fixed orifice and TXV systems.

Smart HVAC control systems with on-board fault detection system have the potential to save all the energy that would otherwise be wasted due to HVAC faults and improper operation. Additionally, such devices will increase the overall life of the HVAC systems and reduce maintenance costs. 


\section{Conclusion}

Handheld indicators are available for HVAC contractor use. No system-integrated indicators were found for homeowners to be alerted to low refrigerant levels in their central air conditioners. DOE should perform continuing and additional research to develop an integrated refrigerant level indicator that is both inexpensive and has light and sound indicators.

Rather than developing a dedicated fault detection system for residential air-conditioners and heat pumps, it should be combined with a control system (thermostat/humidistat) since the same microprocessor can be utilized for fault detection. If less expensive sensors are employed, the comprehensive device would be readily accepted by the market place. Fault detection based on only temperature sensors is attractive since those sensors are less expensive. However, other sensors that enable direct fault detection should be explored. For instance, residential air-conditioners are already equipped with high and low refrigerant pressure cut-off devices and other sensors. These can be utilized and modified to provide fault detection and diagnosis in combination with other additionally sensed parameters. Differential temperature sensors should be explored as well for better accuracy in measurement.

\section{References}

[1] Levins, P.W., Rice, C.K. and Baxter, V.D., "Modeled and measured effects of compressor downsizing in an existing air conditioner/heat pump in the cooling mode," ASHRAE Transactions, Vol. 102, Part 2, 1996, pp. 22-33.

[2] Proctor, J. 2000. "AC Performance Associated with AB970". Presentation to the California Energy Commission. November 28.

www.energy.ca.gov/ab970_standards/documents/presentations/2000-11-28_PROCTOR.PPT.

[3] Neme, C., Proctor, J. and Nadel, S., "Energy Savings Potential from Addressing Residential Air Conditioner and Heat Pump Installation Problems," American Council for an Energy-Efficient Economy, Report Number A992, 1999.

[4] http://www.fielddiagnostics.com/ServiceAssistant.cfm

[5] http://www.istmonitor.com/

[6] http://www.proctoreng.com/checkme/technical.html

[7] http://www.archenergy.com/cec-eeb/P2-Diagnostics/P2-1_Prior_research.htm

[8] Mei, V.C., Chen, F.C., and Gao, Z., "Refrigerant Charge Indicator and Dirty Air Filter Sensor," ORNL/CON-489, February 2003. 
[9] Davis, R.A., "Influence of the Expansion Device on the Performance of a Residential Split-System Air Conditioner," Prepared by Performance Testing and Analysis Unit Technical and Ecological Services, Prepared for Customer Energy Management, PG\&E, Report No.: 491-01.4, January 2001. 


\section{Appendix A: Existing Homes RD\&D Stakeholder Feedback Questionnaire}

The feedback card presented on the next page was used at each of the conference sessions to solicit written recommendations from industry stakeholders on the future direction of DOE existing residential buildings RD\&D. 


\section{The Next Big Thing....}

Be part of the "next big thing" in home energy efficiency: Tell us what you think.

What would help you expand your use of home energy efficiency and renewable energy, and take advantage of the upcoming Federal tax credits? The U.S. Department of Energy performs a variety of research to improve products and practices in energy-related aspects of home building and remodeling. We would like your feedback on where to spend our future research dollars.

1. From your experience, what energy-related products (including building materials) could use improvement?

2. Based on your knowledge of current construction practices, which ones do you think need improvement to increase the energy efficiency of your projects?

3. If you could have any new, energy-related building product at your disposal, what would it be? Or are you aware of a building product that you would like to use that is not readily available to you yet?

4. What information or tools (e.g, software) do you need to design and sell more energy-efficient projects?

5. Do you have any other comments that would help us define how we spend our research dollars to improve energy efficiency and increase the use of renewable energy in existing American homes?

Optional:

Name:

Email:

Company:

Phone:

Address: 


\section{Appendix B: Existing Homes RD\&D Stakeholder Feedback}

The information provided on the next several pages is the original industry feedback compiled from the written feedback forms and recorded on flip charts for each feedback session held at the following conferences:

- The Remodeling Show, Oct. 2005, Baltimore, MD

- Environmental \& Energy Building Association Conference, Oct. 2005, Colorado Springs, CO

- RESNET Conference, Feb. 2006, San Antonio, TX

- ACI, May 2006, Austin, TX.

This information is often abbreviated in nature, and therefore, can be difficult to interpret without having attended the sessions. This feedback has been clarified, sorted, and made easier to understand in Appendices C and D.

The data presented at the end of Appendix B includes the results of participant "voting" performed towards the conclusion of the Affordable Comfort conference session. Voting was used as an alternative approach to previous feedback sessions to have participants (i.e., industry) decide which of the RD\&D ideas generated were the most important for DOE to consider. 


\section{The Remodeling Show, Oct. 2005, Baltimore, MD}

\begin{tabular}{|l|l|}
\hline $\mathbf{1}$ & From your experience, what energy-related "widget" could use improvement? \\
\hline 1 & Retrofitting existing homes with high R-Value insulation. \\
\hline 2 & $\begin{array}{l}\text { Home energy automation devices leading to fully programmable buildings focused on } \\
\text { efficiency to monitor ACH with error codes etc. }\end{array}$ \\
\hline 3 & Ways to seal duct work-nonexistent and inaccessible. Easy ways to perform energy audits. \\
\hline 4 & Solar electric panel which have higher output and which would be economic to install. \\
\hline 5 & Heat-loss monitor, energy-use monitor. \\
\hline 6 & Raise gas boiler's efficiency. \\
\hline 7 & Refrigerators, freezers, and water heaters. \\
\hline 8 & Air make-up systems for new "tight" homes. \\
\hline 9 & Photovoltaic cells, solar hot water heating systems. \\
\hline 10 & Solar electric. \\
\hline 11 & Replacing pilot lights in furnaces and boilers. \\
\hline 12 & New construction window framing. Door seals. \\
\hline
\end{tabular}

\begin{tabular}{|l|l|}
\hline 2 & $\begin{array}{l}\text { Based on your knowledge of current construction practices, which ones do you think } \\
\text { need improvements to increase the energy efficiency of the project? }\end{array}$ \\
\hline 1 & Sealed attics and crawl spaces. \\
\hline 2 & $\begin{array}{l}\text { Education-builders and code officials on strategies and techniques to treat the house as a } \\
\text { system. }\end{array}$ \\
\hline 3 & $\begin{array}{l}\text { Training which remodelers can recommend or require of their HVAC subcontractors (or } \\
\text { partners) to help us learn and adopt better practices. Training on mold risks (airborne, } \\
\text { prevention, remodeler protection). }\end{array}$ \\
\hline 4 & Air-sealing techniques. \\
\hline 5 & Air-exchange systems. \\
\hline 6 & Airflow barrier, house tightness, insulation practices, inspection guidelines. \\
\hline 7 & $\begin{array}{l}\text { The envelope of the building being more efficient. Cheaper lighting solutions with more } \\
\text { power (IE, LED). }\end{array}$ \\
\hline 8 & Vapor burner. \\
\hline 9 & $\begin{array}{l}\text { In a stand alone PV system the batteries are often fully charged by noon. If there was a way } \\
\text { to shunt that potential energy afternoon to heat the domestic hot water that would increase } \\
\text { the efficiency of the system. }\end{array}$ \\
\hline 10 & Corner framing details and acceptance of same by codes and code officials. \\
\hline 11 & $\begin{array}{l}\text { I think that we still need to improve door and window air infiltration as I think that is still the } \\
\text { biggest weakness. }\end{array}$ \\
\hline 12 & Water heaters-make tax credit for on demand water heater. \\
\hline 13 & Sealing gaps in new construction. \\
\hline 14 & $\begin{array}{l}\text { Plate seals (floor to wall). Seals at tees and corners of exterior walls. A product to cover car } \\
\text { lights for prevention of heat loss. }\end{array}$ \\
\hline
\end{tabular}

\begin{tabular}{|l|l|}
\hline 3 & $\begin{array}{l}\text { If you could have a new building product at your disposal that was energy related, } \\
\text { what would it be? Or are you aware of a building product that you would like to use } \\
\text { that is not readily available to you yet? }\end{array}$ \\
\hline 1 & $\begin{array}{l}\text { Inexpensive blower door that comes with a small portable generator and instructions. Every } \\
\text { builder/remodeler needs one. }\end{array}$ \\
\hline 2 & Inexpensive closed cell and open cell foam spraying. \\
\hline 3 & Retrofit of existing attic which could or would allow the attic to be conditioned economically. \\
\hline
\end{tabular}




\begin{tabular}{|l|l|}
\hline 4 & Better and more affordable instant hot water heaters. \\
\hline 5 & Develop a better broom so people would stop buying leaf blowers. \\
\hline 6 & Energy recapture of exhausted air i.e. dryers, vent fans, and water heaters. \\
\hline 7 & Something that would eliminate the power company altogether which is cost effective. \\
\hline 8 & Energy efficiency feedback information to owner so they know what temperature is best, etc. \\
\hline 9 & $\begin{array}{l}\text { I would like to see plywood for walls or possibly roofing that has an outside layer of } \\
\text { insulation foam. That might help us reach the new energy codes without increasing the } \\
\text { thickness. Or, if we could research increasing R value in insulation without increasing the } \\
\text { thickness. }\end{array}$ \\
\hline 10 & Higher "R" on wall insulation. \\
\hline 11 & Window sealants. \\
\hline
\end{tabular}

\begin{tabular}{|l|l|}
\hline $\mathbf{4}$ & $\begin{array}{l}\text { What information or tools (for example, software) do you need to design and sell } \\
\text { more energy efficient projects? }\end{array}$ \\
\hline 1 & Software to calculate savings for improvements. \\
\hline 2 & Indoor air quality software. \\
\hline 3 & $\begin{array}{l}\text { Software DVD or video demos to take to homeowners and display how ENERGY STAR } \\
\text { products will help the efficiency in their home. }\end{array}$ \\
\hline 4 & Software we can use for home improvement projects which will show ROI. \\
\hline 5 & Make a simple way to demonstrate payback benefits of various energy savings products. \\
\hline 6 & $\begin{array}{l}\text { I would like to see a checklist of items related to the actual building process that you could } \\
\text { look at during the design process. }\end{array}$ \\
\hline 7 & Heat loss video. \\
\hline
\end{tabular}

\begin{tabular}{|l|l|}
\hline $\mathbf{5}$ & $\begin{array}{l}\text { Other comments that would help us define how we spend our research dollars to } \\
\text { improve energy efficiency and increase the use of renewable energy in existing } \\
\text { American homes. }\end{array}$ \\
\hline 1 & $\begin{array}{l}\text { Like to see new homes sold with operating manuals that are focused on energy efficiency- } \\
\text { the market may be ready for this. }\end{array}$ \\
\hline 2 & Solar heat as another source of heat along with current system. \\
\hline 3 & More advertising - with energy costs up. \\
\hline 4 & $\begin{array}{l}\text { Marketing for the ideas of energy conservation which will promote more awareness and } \\
\text { demand for conservation. }\end{array}$ \\
\hline 5 & $\begin{array}{l}\text { 0 point energy, nuclear energy, hydrogen, solar act for off grid lighting and cleaner cheaper } \\
\text { power plants. }\end{array}$ \\
\hline 6 & Ground source products. Reduce cost of solar. \\
\hline 7 & $\begin{array}{l}\text { Shower and bath mixing valves that allows setting water temperature before turning water } \\
\text { on; this needs to be promoted more, most of our clients are unaware of this product but love } \\
\text { it after using it. }\end{array}$ \\
\hline 8 & $\begin{array}{l}\text { I would like to see a more efficient way to heat a single family home that would be practical } \\
\text { for builders to use. }\end{array}$ \\
\hline 9 & Bring back solar tax credit. \\
\hline
\end{tabular}




\section{Environmental \& Energy Building Association Conference,} Oct. 2005, Colorado Springs, CO

\begin{tabular}{|l|l|}
\hline $\mathbf{1}$ & From your experience, what energy-related "widget" could use improvement? \\
\hline 1 & DIY insulation, easy to view and access for proper workmanship for the DIY. \\
\hline 2 & $\begin{array}{l}\text { All HVAC products. Fiberglass. All installation training. Monitoring-need to do more of it. } \\
\text { Education. }\end{array}$ \\
\hline 3 & $\begin{array}{l}\text { Low-e, impact resistant, hurricane? Cellulose batts? Rigid fiberglass boards "doesn't burn" } \\
\text { and rockwool? }\end{array}$ \\
\hline 4 & $\begin{array}{l}\text { Large appliances. Large users of energy. Have a standard based on types and sizes so it is } \\
\text { known that not all ENERGY STAR appliances are the same. Plug-in CFLs and lighting } \\
\text { fixtures designated for CFLs. Need more of these in the market. }\end{array}$ \\
\hline
\end{tabular}

\begin{tabular}{|l|l|}
\hline 2 & $\begin{array}{l}\text { Based on your knowledge of current construction practices, which ones do you think } \\
\text { need improvements to increase the energy efficiency of the project? }\end{array}$ \\
\hline 1 & Proper installation of product--training. \\
\hline 2 & $\begin{array}{l}\text { Make air sealing more widespread. Duct sealing. Construction process e.g. too many trips to } \\
\text { jobsite. DVDs of installation. }\end{array}$ \\
\hline 3 & Air sealing for tax credit and duct sealing. \\
\hline 4 & $\begin{array}{l}\text { Coordination between the trades: electrician, plumber, framer, HVAC, etc. All having a } \\
\text { common goal. Usually each will concentrate on their own specialty and doesn't spend the } \\
\text { time or energy to know how one thing could affect another. }\end{array}$ \\
\hline
\end{tabular}

\begin{tabular}{|l|l|}
\hline 3 & $\begin{array}{l}\text { If you could have a new building product at your disposal that was energy related, } \\
\text { what would it be? Or are you aware of a building product that you would like to use } \\
\text { that is not readily available to you yet? }\end{array}$ \\
\hline 1 & $\begin{array}{l}\text { Using hybrid car as a portable cogeneration unit for house and office } \\
\text { heating/cooling/electricity. Toyota's working on it. }\end{array}$ \\
\hline 2 & Simple passive solar. Thermal storage i.e. crystallite water window. \\
\hline 3 & $\begin{array}{l}\text { Nothing in particular, generally speaking there are a lot of great products available. It is } \\
\text { more of a question of getting the builder/contractor to install energy-efficient features. The } \\
\text { knowledge is out there, we just need to have owners and builders to start using all these } \\
\text { great products/ideas. }\end{array}$ \\
\hline
\end{tabular}

\begin{tabular}{|l|l|}
\hline 4 & $\begin{array}{l}\text { What information or tools (for example, software) do you need to design and sell } \\
\text { more energy efficient projects? }\end{array}$ \\
\hline 1 & Online performance predictor. \\
\hline 2 & $\begin{array}{l}\text { Database of retail sources of product: you can get this package, costing that much, in stock } \\
\text { at this retailer, saving \$s till Tuesday. }\end{array}$ \\
\hline 3 & $\begin{array}{l}\text { Very quick and simple methods to show savings and incremental costs/payback for things } \\
\text { like windows, floor heating, lighting, insulation in ceiling, etc. }\end{array}$ \\
\hline
\end{tabular}

\begin{tabular}{|l|l|}
\hline 5 & $\begin{array}{l}\text { Other comments that would help us define how we spend our research dollars to } \\
\text { improve energy efficiency and increase the use of renewable energy in existing } \\
\text { American homes. }\end{array}$ \\
\hline 1 & Educate the public that you exist and how to find the information available. \\
\hline 2 & $\begin{array}{l}\text { Bundle PV, solar DHW and efficiency into a package when marketing to public. "Pay no } \\
\text { income tax next year, } \$ 4500 \text { credit for this } \$ 15000 \text { package which saves } 50 \% \text { of your } \\
\text { energy. Discount financing available." }\end{array}$ \\
\hline 3 & $\begin{array}{l}\text { Most new construction and renovation projects customers are more interested in granite } \\
\text { counters, paint colors, the "spaces" etc. and not in EE. With gas prices increasing } \\
\text { customers will become more concerned with EE but they need to understand what the } \\
\text { benefit of various improvements or incremental changes would be. }\end{array}$ \\
\hline
\end{tabular}




\section{RESNET Conference, Feb./Mar. 2006, San Antonio, TX}

\begin{tabular}{|c|c|}
\hline 1 & From your experience, what energy-related "widget" could use improvement? \\
\hline 1 & Low-cost high-efficiency furnaces. Develop a process for sealing leaky existing homes. \\
\hline 2 & Quick analysis, better tracking. Help with marketing consumer. \\
\hline 3 & Smart HVAC/Air handlers—read flow and Ti/To output running efficiency. \\
\hline 4 & Basement wall insulation (exterior). \\
\hline 5 & $\begin{array}{l}\text { Cardboard vent baffle-foil radiant barrier on attic side. Thermostat that shows consumption } \\
\text { in } \$ \text {. Panel box that shows consumption in } \$ \text {. }\end{array}$ \\
\hline 6 & $\begin{array}{l}\text { For high rise MF energy management control. Snap-in low-e replacement window. Special } \\
\text { electric meter for high use item i.e. ac unit. Advanced electric metering as power is used. } \\
\text { Smart furnace to identify problems. Easier way to seal than Aeroseal (foam at joint). } \\
\text { Insulation in general. Easy seal for unsealed can light. }\end{array}$ \\
\hline 7 & $\begin{array}{l}\text { Batteries for solar. Dryers. Power vents. Non-poisonous foam insulation. Insulation with } \\
\text { higher R-value per inch. Aesthetically acceptable solar collectors. Easily found and } \\
\text { maintained solar products. Burning stoves (wood pellets, corn, wood). }\end{array}$ \\
\hline 8 & $\begin{array}{l}\text { Windows. Roofing felt. Expanding foam e.g. versifoam. More forgiving siding. BIPV. LED. } \\
\text { Lighting controls less \$s. Pin based CFL higher quality. Water heating. Hi-temp CFL } \\
\text { downlight lamps. Real time monitoring of end use/whole house. TOU rate meters (customer } \\
\text { interfaces). Alternative to flex duct. Solar thermal DHW. Cool storage. }\end{array}$ \\
\hline 9 & $\begin{array}{l}\text { Basement wall insulation. Automatic water flow control/sensing. Improved sealants. Cross } \\
\text { current counter flow condensers and coils. Movable insulation (windows). Control for } \\
\text { furnace/ventilator interface. Electric generation from geothermal H.P. }\end{array}$ \\
\hline 10 & $\begin{array}{l}\text { Thermostats-point of lots of useful info: smart, interactive, intuitive, adaptive, when to } \\
\text { change filter where. LED lighting. Light storage. Phosphor. Cardboard vent baffle for radiant } \\
\text { barrier. BIPV. Easy to install leak-less duct systems. Smart meters that show consumption } \\
\text { in dollars. Appliance power meter built in. Nano-technology duct systems. Advanced evap. } \\
\text { Cooling. Finish delta-q so it works. }\end{array}$ \\
\hline 11 & $\begin{array}{l}\text { Rain } \mathrm{H} 2 \mathrm{O} \text { collection devices. Hot } \mathrm{H} 20 \text { heat recovery. Built in appliance usage monitoring. } \\
\text { Event detection. Data loggers } \uparrow \text {. Internet. Low voltage fans } \rightarrow \text { air movement. PV fabrics. } \\
\text { Solar } \mathrm{H} 2 \mathrm{O} \rightarrow \text { elect. } \mathrm{H} 2 \mathrm{O} \text { heater } \rightarrow \text { fridge. Windows lower } \mathrm{u} \text {-value. } \\
\text { Thermostats/controls/point of info. Fitness equipment/kinetic energy as generators. Hinges } \\
\text { on doors all forms of energy } \rightarrow \text { batteries. }\end{array}$ \\
\hline 12 & $\begin{array}{l}\text { Refrigerant based AC systems. Distribution systems. Better insulation for ducts. Boiler } \\
\text { system efficiency. Hot } \mathrm{H} 2 \mathrm{O} \text { distribution systems. Roof cool technologies. Controls for HVAC } \\
\text { (RFID). Swimming pool motor eff. Well pumps eff. Variable speed. Window improvements. } \\
\text { Lighting LED. Solar tube. Solar cells PV eff. Stand-by power cons. of electronic products. } \\
\text { HDTV, PC, etc. }\end{array}$ \\
\hline 13 & $\begin{array}{l}\text { Adaptive products that change with conditions. Improved radiant barriers / reflective } \\
\text { materials. Integrated appliances. Climate specific AC design and categorization. Built-in } \\
\text { efficiency feedback systems-self correcting systems. District } \mathrm{Htg}+\mathrm{H} 2 \mathrm{O}-\text { better utilize } \mathrm{H} 2 \mathrm{O} \\
\text { supply. Conventional } \mathrm{H} 2 \mathrm{O} \text { : instantaneous, combo-H, solar, tank efficiency. }\end{array}$ \\
\hline 14 & $\begin{array}{l}\text { Better insulation application. HVAC commissioning. Easy homeowner metering. Easy to } \\
\text { seal (retrofit) can lights. Entertainment systems. Snap in low-e windows. Advanced metering } \\
\text { at unit level: gas, electric, furnace, ac units, humidity. Better and easier duct sealing. } \\
\text { Building controls-energy management systems. }\end{array}$ \\
\hline 15 & $\begin{array}{l}\text { Energy-efficient garbage disposals. Electric/gas ranges. Microwaves. Computers. Address } \\
\text { phantom load TV and consumer electronics. Attic fans. Reglazing existing windows. Duct } \\
\text { design: shortening runs and solving air loss. Water heaters. Refrigerators. Radiant barriers. } \\
\text { HVAC and humidity control. Training on proper installation of products. }\end{array}$ \\
\hline
\end{tabular}




\begin{tabular}{|c|c|}
\hline 2 & $\begin{array}{l}\text { Based on your knowledge of current construction practices, which ones do you think } \\
\text { need improvements to increase the energy efficiency of the project? }\end{array}$ \\
\hline 1 & Construction quality inspection. Thermal by-pass checklist is good. \\
\hline 2 & $\begin{array}{l}\text { NFRC consumer product directory simplified and posted for consumers. RFID tags on } \\
\text { building products and systems for later data access. Indoor evap. Coils viewable from } \\
\text { outside. Energy assessments before work scope coupled with testing outside coupled with } \\
\text { QA. Holistic approaches to systems interaction. Durability rating system on materials and } \\
\text { processes. ENERGY STAR label or system for existing homes. Train contractors to be } \\
\text { better business people. }\end{array}$ \\
\hline 3 & $\begin{array}{l}\text { Exterior basement wall insulation that can withstand backfilling and freeze/thaw without } \\
\text { damage. }\end{array}$ \\
\hline 4 & $\begin{array}{l}\text { HVAC quality installation issues and the diagnostic testing to improve existing conditions: } \\
\text { refrigerant change, duct testing, airflow, and imbalances in envelope. }\end{array}$ \\
\hline 5 & $\begin{array}{l}\text { Easy access to retrofit ideas, material, products, methods (web based). Sealing wall and } \\
\text { cavities without reconstruction. Standardization and reporting on HVAC start up. Delta Q for } \\
\text { duct leak testing. }\end{array}$ \\
\hline 6 & $\begin{array}{l}\text { NFRC CPD (gamma and ARI) simplified. RFID embedded in appliances and devices. Indoor } \\
\text { evaporative coils viewable from outside. Energy assessment before spending money and } \\
\text { after work. Holistic approaches. Durability rating system (MATCS, PROC). }\end{array}$ \\
\hline 7 & $\begin{array}{l}\text { Low-E storm windows. Ducts. System performance. Crawl space. Environmental control. Air } \\
\text { sealing. Low cost solar water heating. Field study to verify savings. Contractor QA/QC } \\
\text { procedures. }\end{array}$ \\
\hline 8 & $\begin{array}{l}\text { Duct sealing. Installation of HVAC. Air sealing. Installation of boiler control. Moisture } \\
\text { management strategies. Improving IAQ in retrofit projects. Insulation installation. Load } \\
\text { calculations (requiring + implementing). Duct design (new construction). Proper treatment of } \\
\text { crawlspaces (open to building sealed crawlspaces). Basement (insulation, moisture). Mech. } \\
\text { vent for retrofit. Operations training for occupant. }\end{array}$ \\
\hline 9 & $\begin{array}{l}\text { Recessed light cans. Insulation installations. Window seals (replacement). Alignment of air } \\
\text { and thermal barrier. HVAC retrofit sizing. Supply and return sizing (balancing). Air sealing. } \\
\text { Duct sealing. }\end{array}$ \\
\hline 10 & $\begin{array}{l}\text { Duct design and installation (Aeroseal next generation). Air sealing skills and products. } \\
\text { Insulating without voids and high } R \text { value (skills and products). AC install (packaging, } \\
\text { change, A/F, controls). Replacement window installation practices. Internal quality control } \\
\text { processes. Understanding building interactions by non-energy trades (roof, paint, siding). }\end{array}$ \\
\hline 11 & $\begin{array}{l}\text { Existing wall insulation. HVAC equipment retrofit w/o replacement. Crawlspace. Excavation } \\
\text { equipment. Advanced roofing (reflectivity). Duct insulation. Fireplaces. Windows (SHGC } \\
\text { films). }\end{array}$ \\
\hline 12 & $\begin{array}{l}\text { Grey water from sinks to WC. Insulations (RECO for). Use of automatic sensors in } \\
\text { bathrooms, sinks, toilets for home. Control of pressure. Required trade and zone specific } \\
\text { schools for builders, for specialty. Best practices sheet stapled on site. }\end{array}$ \\
\hline 13 & $\begin{array}{l}\text { Easier access to air infiltration devices i.e. weather-strip, seals. Stop promoting solid fuel } \\
\text { devices with no education. Basic QA for trade contractors. HVAC sizing. Incentive programs } \\
\text { for improved practices. Residing to integrate vacuum panels/Aerogels. Insulating attic } \\
\text { hatches. Promote end-user education. Foundation insulation/wall interface. }\end{array}$ \\
\hline 14 & $\begin{array}{l}\text { Diagnostics. HVAC sizing. Testing. Duct seal (hard to reach areas). Roof ventilation } \\
\text { practices. Air sealing. Insulation installation. Pressure imbalances. Poor design of } \\
\text { HVAC/duct system. }\end{array}$ \\
\hline 15 & $\begin{array}{l}\text { Energy assessment (test-in test-out) prior to and after spending any } \$ \text { on home } \\
\text { improvement. Roofing materials that reflect solar heat gain / white roofs cool - zone and } \\
\text { climate specific training. B.S. training and certification. Internal quality control (rating based } \\
\text { on results). Coop non-energy building trades in BS training or building trade. Simplified } \\
\text { consumer product directories based on EE, GAMA, NFRC, ARI, model \#. Whole house } \\
\text { retrofit package with loan program and next generation HVAC. Improved methods to } \\
\text { insulate walls including products (vacuum insulation panels and Aerogels). RECO. RFID } \\
\text { tags for all products related to building performance. Low cost foam that meets fire code. }\end{array}$ \\
\hline
\end{tabular}




\begin{tabular}{|c|c|}
\hline & Way to capture data on home performance over time. \\
\hline 3 & $\begin{array}{l}\text { If you could have a new building product at your disposal that was energy related, } \\
\text { what would it be? Or are you aware of a building product that you would like to use } \\
\text { that is not readily available to you yet? }\end{array}$ \\
\hline 1 & Lighting analysis. \\
\hline 2 & $\begin{array}{l}\text { Solar powered fuel cell. Auto expanding insulation device. Low cost inspection devices. Low } \\
\text { cost hi-eff windows and spray-on. Roof that reflects when hot and absorbs when cold. Smart } \\
\text { air quality system. Pre-fab passive solar components. Tank less water heater on save. }\end{array}$ \\
\hline 3 & $\begin{array}{l}\text { Low e window coating spray. Aesthetic indoor ducts. Maintenance free HVAC system } \\
\text { design. Smart controls with high reliability. Affordable building integrated PV. }\end{array}$ \\
\hline 4 & $\begin{array}{l}\text { Smart energy use monitoring technology at affordable cost for all units, apartments or } \\
\text { homes, easily read and understood by all family types. }\end{array}$ \\
\hline 5 & $\begin{array}{l}\text { Duo guard windows residential. Cooling without compressor. Combo PUT solar H2O. } \\
\text { Residential day lighting control—smart light natural light harvesting. }\end{array}$ \\
\hline 6 & $\begin{array}{l}\text { Smart monitoring technology, non geeky, something that could be interpreted easily by } \\
\text { every family type. Hybrid technology integrating water heating, refrigeration, and maybe } \\
\text { space heating too. Uniform appearance of outdoor AC units. }\end{array}$ \\
\hline 7 & $\begin{array}{l}\text { Fix-a-flat for air infiltration. Education on in-floor heating. Electric generation off geothermal } \\
\text { heat pumps. Integrated micro tank for short draws on a tank less water heater. Economical } \\
\text { integrated air sealing mechanical ventilation package as one product. }\end{array}$ \\
\hline 8 & $\begin{array}{l}\text { Low e in a can, advanced window performance. Duct system that looks good inside a } \\
\text { building (get ducts out of attic and crawl space). New construction techniques to enable } \\
\text { highest levels of efficiency / simplified procedures for delivering efficiency. HVAC systems } \\
\text { without ducts and with concealed indoor equipment e.g. high velocity ducts. Variable refrig. } \\
\text { volume } \rightarrow \text { improvements (e.g. Deikan or L.G.). Maintenance free HVAC equipment. Smart } \\
\text { controls that work. Affordable BIPV. Clean, affordable energy generation in the home. }\end{array}$ \\
\hline 9 & $\begin{array}{l}\text { Duo guard windows commercial and residential. Cooling without compressor. Combo } \\
\text { PV+solar H2O. Residential day lighting controls, smart lights, natural light harvesting. } \\
\text { Dynamic and adaptive window treatments, changing emissivity. Capturing and moving } \\
\text { thermal loads to optimize performance (lots of permutations to this idea). Coop ownership of } \\
\text { ground source HP. Use a pool as thermal storage and recapture. Recycle heat and cooling } \\
\text { within house to optimize. Turn a window into a wall using insulating pellets. Disposable } \\
\text { furnace/AC coil. }\end{array}$ \\
\hline 10 & $\begin{array}{l}\text { Fuel cell. Device that sucks life energy out of the air. Photosynthetic electricity generator for } \\
\text { residence. Algae } \rightarrow \text { energy/food residential factory. Grey water system } \rightarrow \text { stuk/shower. } \\
\text { Gutter mounted nano-hydro systems. Combo comfort/ventilation/humidity control box. Low } \\
\text { cost electro chromic windows. Roof integrated solar water heater. Fridge desuper heater. Air } \\
\text { quality monitor that controls ventilation system in a smart way and has alarm. Better waste } \\
\text { water management without negative stigma. Super fenestration that automatically optimizes } \\
\text { energy use, controllable for view, privacy, etc. }\end{array}$ \\
\hline 11 & $\begin{array}{l}\text { Dome/bubble. Air cleaner/purifier (new technology). Life-cycle labeled products (costs }+ \\
\text { benefits). Instantaneous tank less hot water heaters, lower cost. "Smart vents" for crawl } \\
\text { spaces (controlled by humidistat). }\end{array}$ \\
\hline 12 & $\begin{array}{l}\text { Dryer that uses vacuum to dry clothes (heatless). Attic expanding air mattress with radiant } \\
\text { barrier, moisture barrier, Aerogel. Higher efficiency with proper color indoor lighting. } \\
\text { Pumpable/injectable insulating material that does not blow out the wall, is enviro-friendly, an } \\
\text { effective radiant barrier, fill all gaps. Heat capturing driveway. ERD energy recovery } \\
\text { driveway (parking lots) to recover heat from sun-heated surface and car. CH4 driven } \\
\text { barbecue grill. High r value paint. Virtual office to eliminate commuting to office. }\end{array}$ \\
\hline 13 & $\begin{array}{l}\text { Insulation auto-expanding device. Low cost inspection devices. Low cost high eff windows. } \\
\text { Spray-on low e for windows roof that reflects when hot and absorbs when cold. Smart cost } \\
\text { effective air quality system. Vapor barrier for crawl space. PV connected to fuel cell. Pre-fab } \\
\text { passive solar component. Tank less } \mathrm{H} 2 \mathrm{O} \text { heater on same electric line as tanked water } \\
\text { heater. }\end{array}$ \\
\hline
\end{tabular}




\begin{tabular}{|l|l|}
\hline 3 & $\begin{array}{l}\text { If you could have a new building product at your disposal that was energy related, } \\
\text { what would it be? Or are you aware of a building product that you would like to use } \\
\text { that is not readily available to you yet? (Continued) }\end{array}$ \\
\hline 14 & $\begin{array}{l}\text { Affordable hot water systems. 100\% efficient HVAC or as close to as possible. 100\% eff } \\
\text { renewables at \$ that is affordable. Totally leak free ducts (we don't let pipes leak). Fuel } \\
\text { cells/access. Insulation that air seals, provides vapor barrier and thermal, good for all } \\
\text { applications. Lower cost windows that are efficient. Fossil fuel free HVAC equip. PVC } \\
\text { (installs like) duct system that is totally leak free. Shingles that have an interconnecting } \\
\text { system for energy transmission. }\end{array}$ \\
\hline 15 & $\begin{array}{l}\text { Solar/hydrogen fuel cell. Low cost electrical generation from geothermal heat pump. PVC } \\
\text { like duct system. Smart vent for crawl spaces humidistat controlled. Energy recovery } \\
\text { driveway. Energy recovery pool. Hybrid water heater refrigerator super fenestration, } \\
\text { adaptive. Adaptive roofing, reflects when hot and absorbs when cold. Lifecycle labeling for } \\
\text { EE and green products. Air quality monitor integrated with HRV use. Interior ducts that look } \\
\text { good. Mass market low-cost energy use monitoring for home, easy to use and understand. } \\
\text { Fix-a-flat for air leakage. Adaptive load balancing. Micro hydro turbine to generate power in } \\
\text { home rain gutters. Spray-in vapor barrier for crawl space. }\end{array}$ \\
\hline
\end{tabular}

\begin{tabular}{|c|c|}
\hline 4 & $\begin{array}{l}\text { What information or tools (for example, software) do you need to design and sell } \\
\text { more energy efficient projects? }\end{array}$ \\
\hline 1 & $\begin{array}{l}\text { The knowledge is out there we just need to have people share it better. Trade secrets are } \\
\text { being held too close to chest. }\end{array}$ \\
\hline 2 & $\begin{array}{l}\text { Marketing database to direct targeted marketing. Educate consumers about energy for local } \\
\text { regions. CAD design for projects. Web MD for energy. National energy day. Low interest } \\
\text { rates for energy efficiency. }\end{array}$ \\
\hline 3 & $\begin{array}{l}\text { TV spots-commercial to get folks to "look under the hood" of houses } \rightarrow \text { consumers drive the } \\
\text { market } \rightarrow \text { educate the consumer. Web-home performance M.D. for consumers. }\end{array}$ \\
\hline 4 & $\begin{array}{l}\text { Online accessible energy bills consumption before/after. Better business management } \\
\text { training for delivering home performance. Public school energy class/day. Campaign } \\
\text { promoting HP/efficiency career path. Properly targeted performance based incentives. RFID } \\
\text { labeled appliances, etc. for actual performance on site consumer feedback. }\end{array}$ \\
\hline 5 & Web enabled info technology offsite. \\
\hline 6 & $\begin{array}{l}\text { Smart politicians/effective leaders - continuous monitoring and feedback system in AC units. } \\
\text { Energy information and education built into homes and equipment. Design software with } \\
\text { built in energy analysis. Improved CAD systems. Better web based tools, training, design } \\
\text { instruction. }\end{array}$ \\
\hline 7 & $\begin{array}{l}\text { HVAC simplified tools (smart/interactive) e.g. smart AH - effective ed. tool to end users (boil } \\
\text { bldg. science terms into clear/practical steps. Web home performance (questions entered } \rightarrow \\
\text { sources of info generated). }\end{array}$ \\
\hline 8 & $\begin{array}{l}\text { Educational tools at point of sale for homeowners and contractors. Promote energy } \\
\text { efficiency through TV, newspapers, radio, schools, coupons. }\end{array}$ \\
\hline 9 & $\begin{array}{l}\text { Low interest rate for energy efficiency. SW for homeowners to assess house energy } \\
\text { systems and projects. Shareware for HERS rates. Interactive/adv. Metering. Aggregate } \\
\text { leads, home DB, etc. For target marketing } \rightarrow \text { marketing DB to drive marketing. Educate } \\
\text { consumers with norms for location. }\end{array}$ \\
\hline 10 & $\begin{array}{l}\text { Access to best available arch. drawings of existing home from tax office/govt agency. } \\
\text { Prioritized list of improvements. Live access to building science experts. Access to } \\
\text { appropriate info on consumer behaviors with respective to purchase decisions. More user } \\
\text { friendly software. Provide exposure of raters to consumers (marketing). }\end{array}$ \\
\hline 11 & $\begin{array}{l}\text { Small scale web enabled info technology (thermostats that store data) that allows energy } \\
\text { management. Real time pricing info. }\end{array}$ \\
\hline 12 & $\begin{array}{l}\text { Device that quickly and efficiently gives you existing } r \text { values of walls, windows, etc. Self } \\
\text { reporting devices that tell you how much energy an appliance uses, E-CHIP for energy }\end{array}$ \\
\hline
\end{tabular}




\begin{tabular}{|c|l|}
\hline & $\begin{array}{l}\text { check . Comfort/efficiency evaluator explains or translates technical information into lay } \\
\text { terms. }\end{array}$ \\
\hline 4 & $\begin{array}{l}\text { What information or tools (for example, software) do you need to design and sell } \\
\text { more energy efficient projects? (Continued) }\end{array}$ \\
\hline 13 & $\begin{array}{l}\text { PDA technology that imports data into REM rate and energy gauge. Tool that measures } \\
\text { home usage, examines lifestyle patterns. Occupants behavior modification tools and child } \\
\text { education tool integrated or linked to appliances. Motion detector that incorporates a heat } \\
\text { sensor (occupancy sensor). Phantom loads control system. Tool that uses weather forecast } \\
\text { with home energy products and technologies. }\end{array}$ \\
\hline 14 & $\begin{array}{l}\text { Software to translate technical data from rating for consumer consumption. Web MD for } \\
\text { home performance. Tool to tell us where are house built before. Homeowner behavior } \\
\text { modification. Better CAD/CAM product that links to energy model, scan photos and draw } \\
\text { diagrams, quick way to collect data for model analysis photo } \rightarrow \text { parameters. Access to } \\
\text { best available arch drawings from county assessment or code office. Database of all attic } \\
\text { and wall insulation levels in existing homes (aerial IR image database). PDA interface that } \\
\text { integrates with all energy modeling software. Web enabled energy management system. } \\
\text { Smart air handling system with performance readout. Better business management training } \\
\text { to deliver home performance. Ask RESNET also known as ask JEEVES. }\end{array}$ \\
\hline
\end{tabular}

\begin{tabular}{|l|l|}
\hline 5 & $\begin{array}{l}\text { Other comments that would help us define how we spend our research dollars to } \\
\text { improve energy efficiency and increase the use of renewable energy in existing } \\
\text { American homes. }\end{array}$ \\
\hline 1 & $\begin{array}{l}\text { Have a brainstorm session with people outside of the building industry to identify "the next } \\
\text { big thing". You'll need to think "out of the box" and not limit possible solutions to generally } \\
\text { accepted solutions. }\end{array}$ \\
\hline 2 & $\begin{array}{l}\text { Database of forms that we can quickly copy and not have to start from scratch. Shorten } \\
\text { learning curve for raters so they don't have to develop everything from trial and error. }\end{array}$ \\
\hline
\end{tabular}




\section{ACI, May 2006, Austin, TX}

\begin{tabular}{|c|c|}
\hline 1 & From your experience, what energy-related "widget" could use improvement? \\
\hline 1 & $\begin{array}{l}\text { Vapor barriers-intelligent ones. Solar thermal-PEX collector loops, lower cost, see Howard } \\
\text { Reichmath. Cladding systems-need integral drainage planes. }\end{array}$ \\
\hline 2 & $\begin{array}{l}\text { Concrete products, fasteners self-sealing. Joint compound permeability. Flex ducts- } \\
\text { durability and less air resistance/high } R \text { value. Knob and tube insulating (isolating) material, } \\
\text { easy to install (sonatube). Capillary break materials, paint. Mastic that is machine washable. }\end{array}$ \\
\hline 3 & $\begin{array}{l}\text { Raise the } R \text {-value on windows. } R \text { values are very low and people need their windows. By } \\
\text { raising the } R \text { value, these more energy efficient windows would save money. }\end{array}$ \\
\hline 4 & $\begin{array}{l}\text { Residential desiccants to make CAC more efficient with latent heat. } \\
\text { Heating/cooling/ventilation/humidity master controlling. Secondary heat exchangers of } \\
\text { ENERGY STAR furnaces. 3" to 5" MERV11 air filters/return air registers integrated. More } \\
\text { efficient DHW heaters. More efficient dehumidifiers. Ban unvented space heaters. Reflective } \\
\text { roofing. Batteries }(\mathrm{kW}) \text {. }\end{array}$ \\
\hline 5 & $\begin{array}{l}\text { Increase R value of windows. Quality of work. Adjustable awnings. Blinds in windows. } \\
\text { Flashing to prevent fascia rotting. Solar Vott. Systems. }\end{array}$ \\
\hline 6 & $\begin{array}{l}\text { Easier blower door assembly. Interoperability. Fiber optic inspection scope. Affordable IR } \\
\text { camera. Smoke sticks that last longer, don't corrode, cost less. Wireless cell phone-notepad } \\
\text { for energy audits and other field applications GIS, PC, IR camera, AutoCAD for client home. }\end{array}$ \\
\hline 7 & $\begin{array}{l}\text { Gas tank-type water heater. Improved attic access, pull-down stairway. Non leaky cabinets } \\
\text { (mechanical). Easy way to turn off stand-by load. Intermittent ignition and automatic vents } \\
\text { for converted gas lag sets. }\end{array}$ \\
\hline 8 & $\begin{array}{l}\text { Consumption data stored in meters over time. Accessed via owner permission, loaded onto } \\
\text { blackberry. Program tracking system to collect pre and post energy-use data for all homes } \\
\text { with analysis. How about one set of savings formulae? ENERGY STAR water heater (closed } \\
\text { combustion). Drill bits for wall retrofit (carbide + self feed). Low U value/high transmittance. } \\
\text { Glass for south-facing windows in cold climates. EPS foam fire rated, cove inserted at heel. } \\
\text { Inexpensive hand-held, fish-eye solar path finder. Flow meter for insulation blowing } \\
\text { machines to measure volume/density. Smart thermostats that monitor air temp, MRT, RH, } \\
\text { and air movement (comfort temp). Heat pumps for manufactured homes (current spec } \\
\text { doesn't match with HUD). }\end{array}$ \\
\hline 9 & $\begin{array}{l}\text { Foundation walls. Solar systems. Control AC and heat systems. Geothermal systems. } \\
\text { Ventilation systems/units. Injected foam (side walls) in existing homes. Low flush toilets that } \\
\text { work. Better appliances. Use waste water and other heat: recapture. Improved } \\
\text { home/appliance controls: smarter homes to improve efficiency. Unvented fireplaces- fail- } \\
\text { safe chimney - top dampers for gas fireplaces. }\end{array}$ \\
\hline 10 & $\begin{array}{l}\text { Windows. Smaller furnaces, self-diagnostic performance system. Insulation, open cavities } \\
\text { and existing. Lighting: not fluor. or dimmable. Lower starting temp., outdoor CFLs. Smaller } \\
\text { ACs, no dehumid. Water blown foam with high R value. "Smart" roofs. Roof materials with R } \\
\text { value. Feedback systems that are integrated, constant-monitor efficiency. Plug-load meters } \\
\text { that tell the user how much power is being consumed in "off" and converts it to } \$ \text {. Synthetic } \\
\text { studs with R value. Smart drywall "R-wall" with vapor seal. Point of use flash water heaters } \\
\text { reduce loop. }\end{array}$ \\
\hline 11 & Notepad wireless assessment sheet. ENERGY STAR heat pump for mobile home. \\
\hline 12 & Bath and kitchen vent systems. Feedback systems to show where energy is going. \\
\hline 13 & Windows. Insulation. Automatic air sealing ducts-self sealing ducts. \\
\hline 14 & $\begin{array}{l}\text { Ducts. Sealing attics and basement crawlspace. LEDs. Effective and safe spray foam for } \\
\text { existing homes-closed cell. }\end{array}$ \\
\hline 15 & $\begin{array}{l}\text { Instantaneous feedback to monitor and change load. Miracle flex duct. Better R value } \\
\text { windows. Injectable foam for existing. Easy device to turn off standby loads. KWh batteries } \\
\text { cheap and enviro-friendly. Built in data logger for all appliances. Smaller efficient furnaces. } \\
\text { Heat pumps for manufactured homes. }\end{array}$ \\
\hline 16 & Delta Q - blower door for ducts. Unvented attics and crawlspaces. White LEDs as efficient \\
\hline
\end{tabular}


\begin{tabular}{|c|l|}
\hline & $\begin{array}{l}\text { as incandescent. Entertainment systems. Snap in low-e windows. Advanced metering at unit } \\
\text { level: gas, electric, furnace, ac units, humidity. Better and easier duct sealing. Building } \\
\text { controls - energy management systems. }\end{array}$ \\
\hline 17 & $\begin{array}{l}\text { Unvented attics and crawlspaces. LED lights. LED panel lights, like film. R-10 windows. } \\
\text { Variable sensible heat ratio AC. Instantaneous feedback to monitor cooling load and all } \\
\text { loads. Universal handheld device to facilitate assessments. Cool roofs-reflection of IR. } \\
\text { Water absorbent ground for heat pumps. External instantaneous elec. data logger. }\end{array}$ \\
\hline
\end{tabular}

\begin{tabular}{|c|c|}
\hline 2 & $\begin{array}{l}\text { Based on your knowledge of current construction practices, which ones do you think } \\
\text { need improvements to increase the energy efficiency of the project? }\end{array}$ \\
\hline 1 & $\begin{array}{l}\text { Water management in standard construction is nonexistent-it doesn't matter if the building is } \\
\text { efficient if it rots. Duct systems need to be re-engineered, need to include proper flow, better } \\
\text { registers and seals built into system. }\end{array}$ \\
\hline 2 & Training, workmanship, installation. \\
\hline 3 & $\begin{array}{l}\text { Educate and communicate to/among architect, builder, and contractors about high } \\
\text { performance building practices. Ducts-HVAC. Communicate among trades and continuously } \\
\text { through building process. Hot H2O piping. Air-sealing (constr. details). Moisture control. } \\
\text { Ventilation. Smaller houses, closer together (attached). Bonus rooms. Code enforce. Constr. } \\
\text { management. }\end{array}$ \\
\hline 4 & $\begin{array}{l}\text { Exterior air barrier system. More educated building inspectors (as to energy efficiency). } \\
\text { HVAC in thermal envelope. Oversize wires by one gauge to reduce resistance losses. } \\
\text { Accessible plumb/elect closets for flexibility of upgrades. Slab insulation. Educating } \\
\text { architects/developers on house orientations. }\end{array}$ \\
\hline 5 & $\begin{array}{l}\text { Framing details-educate engineers, architects, developers- party walls better engineered- } \\
\text { corners- space not allowed to seal by code, need to create a better engineered, a way to } \\
\text { seal. Code officials not currently on best practices (better than code). }\end{array}$ \\
\hline 6 & $\begin{array}{l}\text { Foundation wall insulation. Equipment sizing. Duct design. Duct installation. Plumbing } \\
\text { design. "Comprehensive methodology" awareness across crews/trades, etc... Framing } \\
\text { practices (quality control education) nothing new just ignored. Advanced framing, eliminate } \\
\text { thermal bridges. Air sealing. }\end{array}$ \\
\hline 7 & $\begin{array}{l}\text { Understanding effects of install practices especially air sealing, pass knowledge to all } \\
\text { trades. Better training for contractors/crew/installations practices. HVAC contractors install } \\
\text { and test duct systems. Mechanical equipment properly sized. New homes site orientation. } \\
\text { Moisture control systems. Educate trades people about air-tight construction. }\end{array}$ \\
\hline 8 & $\begin{array}{l}\text { Window installation. Solar panel installation mounts. } \downarrow \text { strapping in ceilings (air gaps). Wider } \\
\text { use of raised-heel trusses. Ducting-installation, self sealing. Air-tight solution for panned } \\
\text { floor joists. Indoor electric meter showing cost in dollars. }\end{array}$ \\
\hline 9 & $\begin{array}{l}\text { More efficient framing (less material). Required building science as part vocational training. } \\
\text { Insulation practices need to change. Easy air sealing practices. Region spec., engineers, } \\
\text { arch. need to learn building science. Code officials up to date on building science. Testing } \\
\text { during construction before insulating. Door/air seal. Vent systems. }\end{array}$ \\
\hline 10 & $\begin{array}{l}\text { Duct system/air handler sealing. Use sealed recessed cans everywhere. Use sealed elec. } \\
\text { boxes. Seal all holes/penetrations during construction/remodeling (you punch it you seal it). } \\
\text { Engineer/arch./bldg. Performance const. Plan for shortest duct runs, least number of } \\
\text { chases. Factory-built panelized wall systems. }\end{array}$ \\
\hline 11 & $\begin{array}{l}\text { Training needed to compensate for loss of institutional knowledge. Leaky ragged rooflines. } \\
\text { Attached housing more energy efficient than detached. HVAC sizing and installation. Code } \\
\text { revision (venting etc.). Blower door testing throughout const. Pressure relief valve (blow-out } \\
\text { window) for homes in hurricane/tornado zones. Easy to insulate foundations/rim joist } \\
\text { systems. Journeyman apprenticeship system. }\end{array}$ \\
\hline
\end{tabular}

\begin{tabular}{|l|l}
\hline 3 & If you could have a new building product at your disposal that was energy related,
\end{tabular} what would it be? Or are you aware of a building product that you would like to use that is not readily available to you yet? 


\begin{tabular}{|c|c|}
\hline 1 & $\begin{array}{l}\text { Modular efficient duct systems. Integral drainage, cladding systems for walls. Solar thermal- } \\
\text { modern technology- for } \mathrm{H} 2 \mathrm{O} \text { and heating. }\end{array}$ \\
\hline 2 & Efficient one ton ducted central AC system. \\
\hline 3 & Notepad. \\
\hline 4 & $\begin{array}{l}\text { Good 2-phase toilets. German flex duct very tight. Soy based spray foam insulation. Duct } \\
\text { sealing spray-aerosol. Smaller furnaces and AC. High pressure duct system. Flexible } \\
\text { radiant wall/floor/ceiling self sealing. }\end{array}$ \\
\hline 5 & $\begin{array}{l}\text { Structured plumbing. Self-sealing (idiot proof) windows. AC refrigerant charging level } \\
\text { indicator (whistler). Airflow output temperature sensoring at vent that relays to data } \\
\text { collection. Pay as you go utility billing. True-light instant light CFLs (no warm up time). } \\
\text { "Energy dashboard" system like MPG meter on car. }\end{array}$ \\
\hline 6 & $\begin{array}{l}\text { Fuel cells in homes (natural gas). Vary heat and cool capacity with modulating control. } \\
\text { Thermostat as valve rather than switch. Mini heater/cooler network. Better stacks for wood } \\
\text { stoves. }\end{array}$ \\
\hline 7 & $\begin{array}{l}\text { Building integrated solar (PV \& thermal). PV in the window glass! Radiant night cooling. } \\
\text { Elec, water and gas monitoring device(s) that stores and downloads data. High R windows } \\
\text { at reasonable cost. }\end{array}$ \\
\hline 8 & $\begin{array}{l}\text { Roofs- flexible reflectivity and absorption dependent on air temperature for optimal energy } \\
\text { savings. LEDs in roofing. Integrated AC and dehumidifier that is ENERGY STAR. Occupant } \\
\text { sensitive controller for temperature/humidity/ventilation. Smart ducts: self sealing, self sizing, } \\
\text { self minimizing turbulence. High COP heat pump water heater. Indirect evaporative cooling } \\
\text { combined with CAC and ventilation. }\end{array}$ \\
\hline 9 & $\begin{array}{l}\text { Tank less on-demand water heaters. Insulation for slab edges that is termite proof and easy } \\
\text { to detail. Hi-perm non-collapsible chute for cathedrals to allow dense-pack. Solar water } \\
\text { heating. Low voltage lighting power by PVs. }\end{array}$ \\
\hline 10 & $\begin{array}{l}\text { Pre-fab utility plenum. Heat dump to pre-heat air or fluid for other uses. Cool dump. } \\
\text { Geothermal boosters. Variable speed energy recovery ventilation or HRV. Recycling and } \\
\text { sharing heat sources among appliances e.g. refrigerator coils pre-heating air for clothes } \\
\text { dryer } \rightarrow \text { exhausting to furnace intake. }\end{array}$ \\
\hline 11 & $\begin{array}{l}\text { Solar shingles. HP WH/dehumidifier that works. Finger jointed studs (hard to find). } \\
\text { Alternative EE lighting (not fluorescent) LEDs, fiber optic. Dishwashers that you can turn off } \\
\text { booster heat. Kitchen/yard waste classification system. Better on-site generation } \\
\text { technologies. Plug and play solar hot water systems. }\end{array}$ \\
\hline 12 & $\begin{array}{l}\text { Low U value high transmittance class for south facing houses in cold climate. Turn-key } \\
\text { trombe wall framing systems. Micro-power wind turbine and other collectors. Fail-safe } \\
\text { chimney top damper for gas fireplaces. Jetsons' appliance cache. Self-sealing components } \\
\text { (additives, gaskets, etc). Thermostat responsive to air temperature, MRT, air speed, RH, } \\
\mathrm{CO}, \mathrm{CO} \text {, and CTC controlling: fans, dehumidifier, furnace. Cheap foam. Natural gas fuel } \\
\text { cell. Variable heating and cooling network/capacity. }\end{array}$ \\
\hline
\end{tabular}

\begin{tabular}{|l|l|}
\hline 4 & $\begin{array}{l}\text { What information or tools (for example, software) do you need to design and sell } \\
\text { more energy efficient projects? }\end{array}$ \\
\hline 1 & $\begin{array}{l}\text { Develop a green label to hook onto ENERGY STAR prevent meaningless like LEED } \\
\text { residential from gaining foothold. }\end{array}$ \\
\hline 2 & $\begin{array}{l}\text { Simulation software comprehensive etc. Energy monitoring kit, seeing the effects watching } \\
\text { the savings. Graphic representation. Audit/report software, detection devices/diagnostic } \\
\text { tools, immediate feedback. }\end{array}$ \\
\hline 3 & $\begin{array}{l}\text { User-friendly energy modeling software for use by builders and consumers. Standardized } \\
\text { energy assessment tool/procedure. Studies showing effect of indoor air quality on human } \\
\text { health. DOE and EPA websites, better access/ user-friendliness to get useful information. }\end{array}$ \\
\hline
\end{tabular}

\begin{tabular}{|l|l|}
\hline 4 & $\begin{array}{l}\text { What information or tools (for example, software) do you need to design and sell } \\
\text { more energy efficient projects? (Continued) }\end{array}$ \\
\hline 4 & Low cost IR cameras. Software that has energy efficiency data that's comprehensive. User \\
\hline
\end{tabular}




\begin{tabular}{|l|l|}
\hline 5 & defined air tightness parameters for HVAC design software. \\
\hline 5 & $\begin{array}{l}\text { Client/homeowner education tools. Accurate energy analysis and monitoring software, or } \\
\text { hardware with wireless comm. Component analysis tool for times when whole house } \\
\text { analysis is too much. Case study database (results of previous jobs). Owner's manual and } \\
\text { maintenance guide. }\end{array}$ \\
\hline 6 & Affordable IR camera. Software for active solar design. Public service announcements. \\
\hline 7 & $\begin{array}{l}\text { Intuitive/visual software for energy modeling. Fed. education/PR campaign. Energy audit of } \\
\text { White House. Equal subsidies for cons/eff products and programs (to oil co.). }\end{array}$ \\
\hline 8 & PV phone home. Smart house with simple user interface. \\
\hline 9 & $\begin{array}{l}\text { Integrated design and energy calculation software (common data files - standard input } \\
\text { output files). Graphical energy use output on energy calculation software for "what if" } \\
\text { designing. Info on stainless steel materials in gas condensing HXs. }\end{array}$ \\
\hline
\end{tabular}

\begin{tabular}{|l|l|}
\hline 5 & $\begin{array}{l}\text { Other comments that would help us define how we spend our research dollars to } \\
\text { improve energy efficiency and increase the use of renewable energy in existing } \\
\text { American homes. }\end{array}$ \\
\hline 1 & $\begin{array}{l}\text { DOE research will not diffuse into practice as well as it currently does if the state energy } \\
\text { offices are de-funded as is currently happening. Keep in mind that the SEOs are key to } \\
\text { taking ideas and building them into marketable realities - only then does the private sector } \\
\text { become engaged. The progression is research, development, and demonstration. }\end{array}$ \\
\hline
\end{tabular}




\section{ACI Voting Results}

\begin{tabular}{|l|l|c|}
\hline $\mathbf{1}$ & $\begin{array}{l}\text { From your experience, what energy-related "widget" could use } \\
\text { improvement? }\end{array}$ & Votes \\
\hline 1 & EPS foam/fire-rated cove insert heel. & 2 \\
\hline 2 & Raise the R-value of windows. & 5 \\
\hline 3 & Device to turn off all stand-by losses. & 13 \\
\hline 4 & Automatic air sealing ducts - self sealing ducts. & 1 \\
\hline 5 & ENERGY STAR heat pump for mobile homes. & 5 \\
\hline 6 & Effective and safe spray foam for existing homes - closed cell. & 3 \\
\hline 7 & Instantaneous system for feedback to monitor cooling load + all loads. & 1 \\
\hline 8 & Adjustable awnings. & 4 \\
\hline 9 & Flex ducts - less restriction, more durable, more R value. & 6 \\
\hline 10 & Universal hand held wireless device to facilitate assessments. & 1 \\
\hline 11 & Big cheap rechargeable batteries. & 0 \\
\hline 12 & External instantaneous elec. data logger. & 8 \\
\hline 13 & Smaller efficient furnaces. Condensing water heater with fan coil $90+\%$. & \\
\hline
\end{tabular}

\begin{tabular}{|l|l|c|}
\hline $\mathbf{2}$ & $\begin{array}{l}\text { Based on your knowledge of current construction practices, which ones do } \\
\text { you think need improvements to increase the energy efficiency of the } \\
\text { project? }\end{array}$ & Votes \\
\hline 1 & $\begin{array}{l}\text { Educate trades people how to effectively air seal with blower doors + "you make } \\
\text { the hole, you seal it". }\end{array}$ & 11 \\
\hline 2 & $\begin{array}{l}\text { Educate and communicate through Whole Food chain (esp. architects) on } \\
\text { advanced home performance. }\end{array}$ & 8 \\
\hline 3 & Less complex roof designs. & 4 \\
\hline 4 & Air-tight substitute for panned floor joists. & 2 \\
\hline 5 & $\begin{array}{l}\text { Framing practices (QC/education). Advanced framing, eliminate thermal bridges, } \\
\text { air sealing, etc. }\end{array}$ & 2 \\
\hline 6 & $\begin{array}{l}\text { Engineer on site + on team understands building science and weaves it into } \\
\text { entire process. }\end{array}$ & 2 \\
\hline 7 & $\begin{array}{l}\text { Ongoing measurement during construction, apply all applicable building science } \\
\text { measurements for ongoing feedback. }\end{array}$ & 1 \\
\hline 8 & Educate everyone in energy efficient components of framing details. & 1 \\
\hline 9 & Build only attached common-wall single family homes. & 1 \\
\hline 10 & Non roof penetrating solar panel attachment system. & 4 \\
\hline 11 & Siting and subdivision design for better current and future solar installation. \\
\hline
\end{tabular}

\begin{tabular}{|l|l|c|}
\hline $\mathbf{3}$ & $\begin{array}{l}\text { If you could have a new building product at your disposal that was energy } \\
\text { related, what would it be? Or are you aware of a building product that you } \\
\text { would like to use that is not readily available to you yet? }\end{array}$ & Votes \\
\hline 1 & PV embedded in window glass. & 8 \\
\hline 2 & Waste heat recovery from refrigerator for space and water heating. & 2 \\
\hline 3 & Flexible wall, floor, ceiling radiant heat. & 0 \\
\hline 4 & Use solar energy for highly efficient lighting. & 1 \\
\hline 5 & Self sealing building components. & 0 \\
\hline 6 & Structured plumbing on-demand water system. & 3 \\
\hline 7 & Heat pump high COP reliable water heater. & 9 \\
\hline
\end{tabular}




\begin{tabular}{|l|l|c|}
\hline $\mathbf{3}$ & $\begin{array}{l}\text { If you could have a new building product at your disposal that was energy } \\
\text { related, what would it be? Or are you aware of a building product that you } \\
\text { would like to use that is not readily available to you yet? (Continued) }\end{array}$ & Votes \\
\hline 8 & Smart ducts - self sealing, self sizing, self minimizing turbulence. & 10 \\
\hline 9 & Kitchen/yard waste gasification system. & 1 \\
\hline 10 & "Energy dashboard" for the home: elec., gas, and water. & 10 \\
\hline 11 & Networking of mini-heating and cooling technologies. & 0 \\
\hline 12 & Networked micro-PV systems. & 2 \\
\hline
\end{tabular}

\begin{tabular}{|c|l|c|}
\hline $\mathbf{4}$ & $\begin{array}{l}\text { What information or tools (for example, software) do you need to design and } \\
\text { sell more energy efficient projects? }\end{array}$ & Votes \\
\hline 1 & Smart house with simple interface so appliances call for service. & 8 \\
\hline 2 & Subsidize EE products to same level fossil energy is getting subsidized. & 10 \\
\hline 3 & Standard software of building, data (between CAD, energy simulations, etc.). & 10 \\
\hline 4 & Low cost IR cameras. & 11 \\
\hline 5 & User-friendly access to DOE + EPA websites to information. & 4 \\
\hline 6 & Quick alert or public info on CO danger of running generators in attached garages. & 1 \\
\hline
\end{tabular}




\section{Appendix C: Existing Homes RD\&D Stakeholder Feedback by End-Use Category (and Evaluation Criteria)}

\section{KEY:}

Categories for Stakeholder Feedback

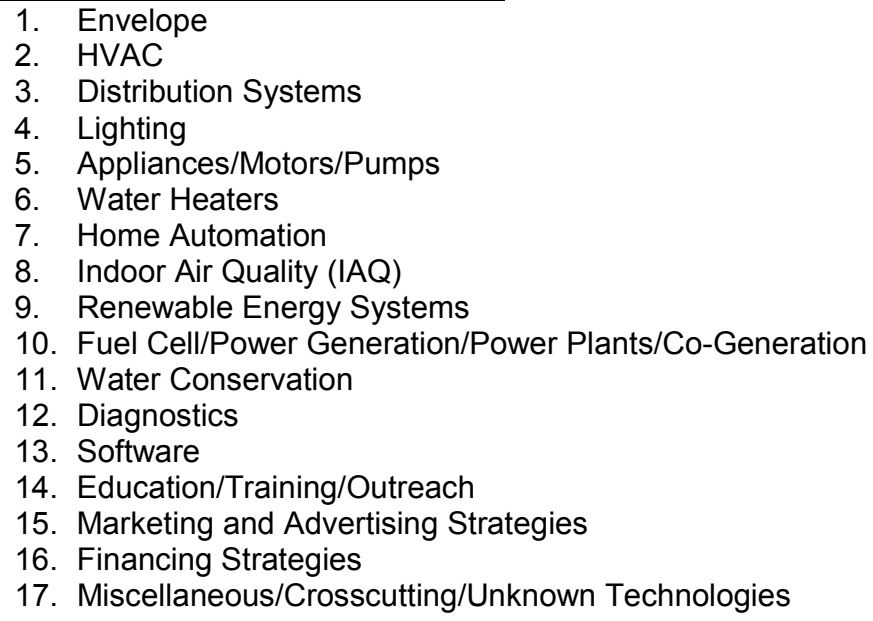

Evaluation Categories for Feedback (listed after each feedback entry below)

$1=$ Generic in nature...feedback is not specific enough to guide DOE's research

$2=$ Already exists in marketplace (at least in some form)

3 = Needed in marketplace (" $3+$ " = needed to a large extent; " $3-$ " = needed to a small extent)

4 = Classification unknown or feedback unclear

$5=$ Not applicable to existing housing or DOE cannot perform associated research

$6=$ Responsibility of other DOE program offices or federal agencies

\section{FEEDBACK:}

\section{Envelope}

[Keywords: Envelope, air/vapor/radiant barriers, insulation, windows, doors, wall/framing, foundation/basement/crawlspace/slab on grade, attics, roofs, paint, and home air sealing including caulking, weather stripping, and sealants]

1) Retrofitting existing homes with high $R-V a l u e$ insulation 1

2) Effective and safe spray foam for existing homes-closed cell 2

3) Fiberglass and insulation (+ application) in general 1

4) Insulation that air seals, provides vapor barrier and thermal, good for all applications 2

5) Easy seal for unsealed can light 3+

6) Better slab insulation 2

7) Easier way to seal than Aeroseal (foam at joint) 3-

8) Sealing attics and basement crawlspace 3-

9) Better door Seals 2

10) DIY insulation, easy to view and access for proper workmanship for the DIY 2

11) Cellulose batt insulation 2

12) Auto expanding insulation device 2

13) Better air sealing techniques 2

14) Better air flow barriers 2

15) House tightness- envelope of the house 2

16) EPS foam fire-rated, cove inserted at heel 4

17) Inexpensive closed cell and open cell foam spraying 3 
18) Movable insulation (windows) 2

19) Soy-based spray foam insulation 2

20) Expanding foam e.g. versifoam 2

21) Attic expanding air mattress with radiant barrier, moisture barrier, Aerogel 4

22) Non-poisonous foam insulation 4

23) Insulation with higher R-value per inch 3

24) Rigid fiberglass boards "doesn't burn" and rockwool 3-

25) Basement wall insulation (exterior) that can withstand backfilling and freeze/thaw without damage that can withstand backfilling and freeze/thaw without damage 3-

26) Develop a process for sealing leaky existing homes 2

27) High R-value paint 4

28) Advanced framing, eliminate thermal bridges 2

29) New construction window framing - Snap in low-e replacement window 3-

30) Reglazing existing windows 4

31) Windows: Low-e, impact resistant, hurricane? (SHGC films) 2

32) Raise the R-value on windows (R-10) 3

33) Turn a window into a wall using insulating pellets 3

34) Duo guard windows residential 4

35) Roof materials with a R-value 3

36) Insulating roofing felt 3

37) Exterior air barrier system 2

38) Cardboard vent baffle for radiant barrier- foil radiant barrier on attic side 4

39) More forgiving siding 5

40) Retrofit of existing attic which could or would allow the attic to be conditioned economically 3

41) Improved sealants, window sealants 3-

42) Roof cool technologies - reflects when hot and absorbs when cold 3-

43) Improved radiant barriers/reflective materials 3

44) Vapor barriers - intelligent ones - spray-in - for crawlspace 3-

45) Cladding systems - need integral drainage planes 5

46) Joint compound permeability 3-

47) Knob and tube insulating (isolating) material, easy-to-install (sonatube) 3-

48) Capillary break materials, paint 2

49) Flashing to prevent fascia rotting 2

50) Improved attic access, pull-down stairway 3-

51) Drill bits for wall retrofit (carbide and self-feed) 3-

52) Better foundation wall systems 2

53) Smart drywall "R-wall" with vapor seal 3

54) Corner framing details and acceptance of same by codes and code officials 2

55) Improve door and window air infiltration as that is still the biggest weakness 2

56) Plate seals (floor to wall). Seals at tees and corners of exterior walls 2

57) Plywood for walls or possibly roofing that has a outside layer of insulation foam. That might help reach the new energy codes without increasing the thickness 3

58) Research increasing R-value in insulation without increasing the thickness 3

59) Alignment of air and thermal barrier 2

60) Best practices for insulating attic hatches 3-

61) Shingles that have an interconnecting system for energy transmission 4

62) Turn-key trombe wall framing systems 4

63) Less complex roof designs 2

64) Self-sealing building components $3+$

65) Easier access to air infiltration devices, i.e. weather stripping, seals 2

66) A product to cover can lights for prevention of heat loss $3+$

$67)$ Concrete products, fasteners self-sealing 3-

68) Blinds in windows 2

69) Synthetic studs with R-value 3+

70) Better vapor barriers 2

71) Moisture management strategies 2

72) Finger-jointed studs (hard to find) 3- 


\section{HVAC}

[Keywords: HVAC, furnaces, air conditioners, boilers, heat recovery, whole-house ventilation, exhaust fan/ventilation, fireplaces and wood burning stoves, heat pumps, and thermal storage]

1) Raise gas boiler's efficiency 3-

2) HVAC and humidity control 3

3) HVAC retrofit sizing 2

4) Fossil fuel free HVAC equip 3-

5) HVAC systems without ducts and with concealed indoor equipment 3

6) Replacing pilot lights in furnaces and boilers 2

7) All HVAC products (plus commissioning) 1

8) Maintenance-free HVAC system design 5

9) Use a pool as thermal storage and recapture 4

10) Variable sensible heat ratio AC 4

11) Integrated $A C$ and dehumidifier that is ENERGY STAR尺 3

12) Efficient one-ton ducted central $A C$ system 3

13) Low-cost high efficiency furnaces 2

14) Disposable furnace/AC coil 5

15) Smart HVAC/air handlers - read flow and Ti/To output running efficiency 3

16) Smart furnace to identify problems 3

17) Burning stoves (wood pellets, corn, wood) 2

18) Better stacks for wood stoves 3-

19) Advanced evaporative cooling 3

20) Hot-water heat recovery 2

21) Low-voltage fans $\rightarrow$ air movement 3-

22) Refrigerant-based AC systems 2

23) Climate specific AC design and categorization 2

24) Better attic fans 2

25) Heat capturing driveway, ERD energy recovery driveway (parking lots) to recover heat from sun 3

26) Residential desiccants to make CAC more efficient with latent heat 3

27) Secondary heat exchangers of ENERGY STAR furnaces 4

28) Heat pumps for manufactured homes (current spec does not match with HUD) 4

29) Use waste water and other heat recapture 2

30) Unvented fireplaces- fail-safe chimney - top dampers for gas fireplaces 5

31) Bath and kitchen vent systems 3-

32) "Smart vents" for crawl spaces (controlled by humidistat) 3-

33) Energy recapture of exhausted air i.e. dryers, vent fans, water heaters 3-

34) Economical integrated air sealing mechanical ventilation package as one product 4

35) Indirect evaporative cooling combined with CAC and ventilation 3-

36) Fail-safe chimney top damper for gas fireplaces 5

37) Capturing and moving thermal loads within conditioned space to optimize performance 3

38) Intermittent ignition and automatic vents for converted gas lag sets 3-

39) Cool storage 2

40) Cross current counter flow condensers and coils 3-

41) Indoor evaporator Coils viewable from outside 3-

42) Adaptive products that change with conditions 2

43) Recycle heat and cooling within house to optimize 3

44) Non-leaky cabinets (mechanical) 3+

45) Cooling without compressor 2

46) Uniform appearance of outdoor AC units 5

47) Water-absorbent ground for heat pumps 3-

\section{Distribution Systems}

[Keywords: Distribution systems, ductwork, duct design, and duct sealing]

1) Ways to seal duct work and nonexistent and inaccessible 3-

2) Alternative to flex duct - Miracle flex duct 3+

3) Easy-to-install leakless duct systems 3+

4) Nano-technology duct systems 3

5) Better distribution systems 1 
6) Automatic air sealing ducts - self-sealing ducts 3

7) Better insulation for ducts 3

8) Insulted hot-water distribution systems 3

9) Duct design, shortening runs, solving air loss 2

10) Flex ducts - durability and less air resistance/high R-value 3-

11) Mastic that is machine washable? 5

12) Supply and return sizing (balancing) 2

13) Aesthetic indoor ducts 3-

14) Duct systems need to be re-engineered, need to include proper flow, better registers and seals built into system 3+

15) Insulated hot-water piping 3

\section{Lighting}

[Keywords: Lighting, CFLs, lighting fixtures, and daylighting]

1) Plug-in CFLs and lighting fixtures designated for CFLs. Need more of these in the market 3-

2) LED lighting 3-

3) Lighting controls and less expensive pin-based CFL - higher quality 3-

4) Hi-temp CFL downlight lamps 3-

5) Light storage-phosphor 4

6) Solar tubes 2

7) Lighting: fluorescents not dimmable - lower starting temperature 3-

8) Outdoor CFLs 2

9) Residential daylighting control - smart light natural light harvesting 3-

\section{Appliances/Motors/Pumps}

[Keywords: Appliances, motors, and pumps]

1) More efficient and lower cost refrigerators, freezers, dryers 2

2) Large appliances large users of energy - have a standard based on types and sizes so it is known that not all ENERGY STAR appliances are the same 3-

3) Power vents 2

4) Swimming pool motor efficiency 3-

5) Well pumps efficiency 3-

6) More use of variable-speed motors in equipment and appliances 1

7) Easy way to turn off stand-by power consumption of electronic products - HDTV, PC, etc. 3

8) Integrated appliances 3

9) Energy-efficient garbage disposals 3-

10) More efficient electric and gas ranges 3-

11) More efficient microwaves 3-

12) More efficient computers 2

13) More efficient entertainment systems 3-

14) Ban unvented space heaters 6

15) Water heater integrated with refrigerator 3

16) Dryer that uses vacuum to dry clothes (heatless) 2

\section{Water Heaters}

[Keywords: Water heaters]

1) More efficient water heaters 3-

2) Gas tank-type water heater 2

3) ENERGY STAR water heaters (closed combustion) 3-

4) Point-of-use flash water heaters reduce loop 4

5) Make tax credit for on-demand water heater 5

6) Better and more affordable instantaneous hot water heaters 3-

7) Tankless water heater with 'save' mode 3-

8) Integrated micro tank for short draws on a tankless water heater 3- 
9) High COP heat pump water heater 3-

10) Conventional water heater to instantaneous, combo-H, solar, tank efficiency 4

\section{Home Automation}

[Keywords: Load/energy monitors (e.g., temperature, humidity, etc.), humidistat, thermostats, meters, data loggers, controls, web-enabled technology (i.e. interactive, wireless), and motion detectors]

1) Home energy automation devices leading to fully programmable buildings focused on efficiency to monitors $\mathrm{ACH}$ with error codes etc. 3+

2) Heating/cooling/ventilation/humidity master controlling 2

3) Heat loss monitor, energy use monitor 3+

4) Monitoring - need to do more of it $\rightarrow$ education $3+$

5) Quick analysis, better tracking 3+

6) Use of automatic sensors in bathrooms, sinks, toilets for home 2

7) Thermostat or panel box that shows consumption in dollars $3+$

8) For high-rise multifamily building energy management control 5

9) Special electric meter for high use item, i.e. AC unit 3+

10) Pay-as-you-go utility billing 3+

11) Advanced electric metering as power is used - show consumption in dollars at unit level $3+$

12) Real-time monitoring of end use/whole house $3+$

13) TOU rate meters (customer interfaces) 3+

14) Control for furnace/ventilator interface 3-

15) Thermostats - point of lots of useful information - smart, interactive, intuitive, adaptive, when to change filter and where $3+$

16) Thermostat as valve rather than switch 4

17) Appliance power meter built in $3+$

18) Built-in appliance usage monitoring, event detection - data loggers tied to the Internet $3+$

19) Thermostats/controls/point-of-use information 3+

20) Controls for HVAC (RFID) 3+

21) Built-in efficiency feedback systems - self-correcting systems 3

22) AC refrigerant charging level indicator (whistle) 3+

23) Instantaneous feedback to monitor and change load $3+$

24) Program tracking system to collect pre- and post-energy-use data for all homes with analysis 2

25) Online performance predictor 4

26) Flow meter for insulation blowing machines to measure volume/density 4

27) RFID tags on building products and systems for later data access 3-

28) Motion detector that incorporates a heat sensor (occupancy sensor) 3-

29) Tool that uses weather forecast with home energy products and technologies 3-

\section{Indoor Air Quality (IAQ)}

[Keywords: Indoor air quality and IAQ]

1) Air make-up systems for new "tight" homes 2

2) 3" to 5" MERV11 air filters/return air registers integrated 4

3) More efficient dehumidifiers 3+

4) Better air exchange systems 2

5) Improving IAQ in retrofit projects 1

6) Air cleaner/purifier (new technology) 4

7) Air quality monitor integrated with HRV use 5

8) Studies showing effect of indoor air quality on human health 5

\section{Renewable Energy Systems}

[Keywords: Solar thermal/domestic hot water, photovoltaics (PV), and passive solar]

1) Solar electric panel which have higher output and which would be economic to install 6

2) Photovoltaic cells, PV fabrics 6

3) Solar panel installation mounts 5

4) Plug and play solar hot water systems 6 
5) BIPV 3-

6) Solar hot water heating systems 6

7) Better batteries for solar 6

8) Roof-integrated solar water heater 3-

9) Aesthetically acceptable solar collectors 3-

10) Easily found and maintained solar products 6

11) Combo PV plus solar water heating 6

12) Mainstream low-voltage lighting and appliance power by PVs 3-

13) PV in the window glass 3-

14) Solar shingles 3 -

15) Micro-hydro turbine to generate power in home rain gutters 4

16) Solar thermal-PEX collector loops, lower cost 4

17) Glass for south-facing windows in cold climates 4

18) In a stand alone PV system, the batteries are often fully charged by noon. If there were a way to shunt that potential energy afternoon to heat the domestic hot water that would increase the efficiency of the system 4

19) Solar heat as another source of heat along with current system 2

20) Zero-point energy, nuclear energy, hydrogen, solar act for off grid lighting and cleaner cheaper power plants 5

21) Simple passive solar, thermal storage, i.e. crystallite water window 3

22) Pre-fabricated passive solar components 3

23) PV connected to fuel cell 6

24) Micro-power wind turbine and other collectors 6

25) Solar water combined with solar electric 4

26) KWh batteries cheap and environmentally friendly 6

27) Adjustable awnings 2

\section{Fuel Cell/Power Generation/Power Plants/Co-generation}

[Keywords: Fuel cell, power generation, power plants, and co-generation]

1) Electric generation from geothermal heat pumps 5

2) Fitness equipment/kinetic energy as generators 6

3) Geothermal systems 6

4) Access to practical fuel cells 6

5) Better on-site generation technologies 6

6) Solar/hydrogen fuel cell 6

7) Using hybrid car as a portable cogeneration unit for house and office heating cooling electricity 6

8) Low-cost electric generation off geothermal heat pumps 6

9) Clean, affordable energy generation in the home 6

10) Something that would eliminate the power company altogether which is also cost-effective 3-

\section{Water conservation}

[Keywords: Grey water/rain water, waste water, plumbing fixtures, and potable water]

1) Automatic water flow control/sensing 5

2) Water management in standard construction is nonexistent 5

3) Rain water collection devices 5

4) Better utilize water supply 5

5) Low-flush toilets that work 5

6) Shower and bath mixing valves that allows setting water temperature before turning water on; this needs to be promoted more 2

7) Grey water from sinks to water closet 5

8) Better waste water management without negative stigma 5 


\section{Diagnostics}

[Keywords: Energy audits/assessments, blower doors, inspection, database, and infrared cameras]

1) Easy ways to perform energy audits 2

2) Easier blower door assembly 2

3) Energy audit of the White House 5

4) Affordable IR camera 3-

5) Notepad wireless assessment sheet - universal handheld device to facilitate assessments

6) Delta Q - blower door for ducts 3-

7) Inexpensive blower door that comes with a small portable generator and instructions 3-

8) Energy assessment (test-in test-out) prior to and after spending any dollars on home improvement 2

9) Low-cost inspection devices 3-

10) Device that quickly and efficiently gives you existing R-values of walls, windows, etc. 4

11) Database of all attic and wall insulation levels in existing homes (aerial IR image database) 4

12) Database of forms that we can quickly copy and not have to start from scratch 3-

13) Testing during construction before insulating 4

14) Standardized energy assessment tool/procedure 3-

15) Wireless cell phone-notepad for energy audits and other field applications GIS, PC, IR camera, AutoCAD for client home 3-

16) Thermal by-pass checklist is good 3-

17) A checklist of items related to the actual building process that you could look at during the design process 5

18) Fiber-optic inspection scope 3 -

19) Smoke sticks that last longer, do not corrode, and cost less 3-

20) Inexpensive hand-held, fish-eye solar path finder 3-

\section{Software}

[Keywords: Software]

1) Software to calculate savings for improvements and ROI 3-

2) Indoor air quality software 5

3) CAD design for projects - design software with built in energy analysis 3-

4) Web home performance (questions entered $\rightarrow$ sources of info generated) 2

5) Software for active solar design 6

6) Make a simple way to demonstrate payback benefits of various energy savings products 2

\section{Education/Training/Outreach}

[Keywords: Education, training, outreach, consumers, contractors, remodelers, code officials, and others]

1) Training on proper installation of products 2

2) Operations training for occupant 3-

3) Ask RESNET like "Ask Jeeves" 4

4) Better energy code enforce 5

5) Code revision (e.g., on venting, etc.) 6

6) Understanding building interactions by non-energy trades (roof, paint, siding) 4

7) Quality of work, Construction quality inspection 5

8) Required trade and zone specific schools for builders, for specialty - best practices sheet stapled on site 5

9) Stop promoting solid fuel devices with no education 4

10) Framing practices (quality control education) nothing new just ignored 2

11) Occupants behavior modification tools and child education tool integrated or linked to appliances 3-

12) Train contractors to be better business people 3-

13) NFRC consumer product directory, CPD (gamma and ARI) simplified 5

14) Education: builders and code officials on strategies and techniques: to the house as a system 2

15) Training which remodelers can recommend or require of their HVAC subcontractors (or partners) to help us learn and adopt better practices 2

16) The knowledge is out there we just need to have people share it better 2

17) Training on mold risks, airborne, prevention, remodeler protection 5 
18) Inspection guidelines 2

19) Durability rating system (MATCS, PROC) 5

20) Contractor QA/QC procedures 2

21) Software, DVD or video demo's to take into homeowner and display how ENERGY STAR products will help the efficiency in their home 2

22) Heat loss video 2

23) Database of retail sources of product: you can get this package, costing that much, in stock at this retailer, saving dollars until Tuesday 5

24) Easy access to retrofit ideas, material, products, methods (web-based) 2

25) New homes sold with operating manuals that are focus on energy efficiency - the market may be ready for this $3+$

26) DVD's of installation 2

27) Coordination between the trades: electrician, plumber, framer, HVAC, etc. 3-

28) Educate the public that you exist and how to find the information available 2

29) Incentive programs for improved practices 2

30) Education on in-floor heating 3-

31) A national energy day 2

32) Public school energy class/day 2

33) Quick alert or public info on co danger of running generators in attached garages 5

34) Educational tools at point of sale for homeowners and contractors 2

35) Access to best available architectural drawings of existing home from tax office/government agency 5

36) Live access to building science experts 5

37) DOE and EPA websites, better access/ user-friendliness to get useful information 2

38) Case study database (results of previous jobs) 3-

39) Owner's manual and maintenance guide 2

40) Public service announcements 2

41) The knowledge is out there, we just need to have owners and builders to start using all these great products/ideas 2

\section{Marketing and Advertising Strategies}

[Keywords: Marketing, advertising, and campaign]

1) Help with marketing to consumer: Marketing for the ideas of energy conservation which will promote more awareness and demand for conservation 6

2) More advertising since energy costs are rising 6

3) Bundle PV, solar DHW and efficiency into a package when marketing to public. "Pay no income tax next year" $\$ 4,500$ credit for this $\$ 15,000$ package which saves $50 \%$ of your energy. Discount financing available 6

4) Marketing database to direct targeted marketing 6

5) Campaign promoting HP/efficiency career path 6

6) Promote energy efficiency through TV, newspapers, radio, schools, coupons 6

7) SEOs are key to taking ideas and building them into marketable realities 6

\section{Financing Strategies}

[Keywords: Financing, interest rates, incentives, and subsidies]

1) Coop ownership of ground-source heat pumps 6

2) Low-interest rates for energy efficiency 2

3) Equal subsidies for conservation/efficiency products and programs as supply-side 5

\section{Miscellaneous/Crosscutting/Unknown Technology}

1) Hinges on doors all forms of energy $\rightarrow$ batteries 4

2) Device that sucks life energy out of the air 4

3) Hybrid technology integrating water heating, refrigeration, and maybe space heating too 3

4) Holistic approaches to systems interaction 2

5) Develop a better broom so people would stop buying leaf blowers 3-

6) Construction process e.g. too many trips to jobsite 3-

7) Hydrogen-driven barbecue grill 3- 
8) Virtual office to eliminate commuting to office 2

9) Smaller houses, closer together (or attached) 2

10) Oversize wires by one gauge to reduce resistance losses 3-

11) Accessible plumbing/electrical closets for flexibility of upgrades 6

12) Kitchen/yard waste classification system 6 


\section{Appendix D: Existing Homes RD\&D Stakeholder Feedback by Evaluation Criteria}

\section{KEY:}

\section{Evaluation Categories for Feedback}

$1=$ Generic in nature...feedback is not specific enough to guide DOE's research

$2=$ Already exists in marketplace (at least in some form)

3 = Needed in marketplace (" $3+$ " = needed to a large extent; "3-" = needed to a small extent)

$4=$ Classification unknown or feedback unclear

$5=$ Not applicable to existing housing or DOE cannot perform associated research

$6=$ Responsibility of other DOE program offices or federal agencies

\section{FEEDBACK:}

\section{1 = Generic in nature...feedback is not specific enough to guide DOE's research}

1. Fiberglass and insulation (+ application) in general

2. Retrofitting existing homes with high R-Value insulation

3. All HVAC products (plus commissioning)

4. Better distribution systems

5. More use of variable-speed motors in equipment and appliances

6. Improving IAQ in retrofit projects

\section{2 = Already exists in marketplace (at least in some form)}

1. Insulation that air seals, provides vapor barrier and thermal, good for all applications

2. DIY insulation, easy to view and access for proper workmanship for the DIY

3. Corner framing details and acceptance of same by codes and code officials

4. Improve door and window air infiltration as that is still the biggest weakness

5. Plate seals (floor to wall). Seals at tees and corners of exterior walls

6. Corner framing details and acceptance of same by codes and code officials

7. Improve door and window air infiltration as that is still the biggest weakness

8. Plate seals (floor to wall). Seals at tees and corners of exterior walls

9. Program tracking system to collect pre- and post-energy-use data for all homes with analysis

10. Shower and bath mixing valves that allows setting water temperature before turning water on; this needs to be promoted more

11. Energy assessment (test-in test-out) prior to and after spending any dollars on home improvement

12. Web home performance (questions entered $\rightarrow$ sources of info generated)

13. Make a simple way to demonstrate payback benefits of various energy savings products

14. Framing practices (quality control education) nothing new just ignored

15. Education: builders and code officials on strategies and techniques: to the house as a system

16. Training which remodelers can recommend or require of their HVAC subcontractors (or partners) to help us learn and adopt better practices

17. The knowledge is out there we just need to have people share it better

18. Software, DVD or video demo's to take into homeowner and display how ENERGY STAR products will help the efficiency in their home

19. Easy access to retrofit ideas, material, products, methods (web-based)

20. Educate the public that you exist and how to find the information available

21. Educational tools at point of sale for homeowners and contractors

22. DOE and EPA websites, better access/ user-friendliness to get useful information

23. The knowledge is out there, we just need to have owners and builders to start using all these great products/ideas

24. Effective and safe spray foam for existing homes-closed cell

25. Better slab insulation

26. Better door Seals

27. Cellulose batt insulation

28. Auto expanding insulation device 
29. Better air sealing techniques

30. Better air flow barriers

31. House tightness- envelope of the house

32. Movable insulation (windows)

33. Soy-based spray foam insulation

34. Expanding foam e.g. versifoam

35. Develop a process for sealing leaky existing homes

36. Advanced framing, eliminate thermal bridges

37. Windows: Low-e, impact resistant, hurricane? (SHGC films)

38. Exterior air barrier system

39. Capillary break materials, paint

40. Flashing to prevent fascia rotting

41. Better foundation wall systems

42. Alignment of air and thermal barrier

43. Less complex roof designs

44. Blinds in windows

45. Better vapor barriers

46. Moisture management strategies

47. HVAC retrofit sizing

48. Replacing pilot lights in furnaces and boilers

49. Low-cost high efficiency furnaces

50. Burning stoves (wood pellets, corn, wood)

51. Hot-water heat recovery

52. Refrigerant-based AC systems

53. Climate specific $A C$ design and categorization

54. Better attic fans

55. Use waste water and other heat recapture

56. Cool storage

57. Adaptive products that change with conditions

58. Cooling without compressor

59. Duct design, shortening runs, solving air loss

60. Supply and return sizing (balancing)

61. Solar tubes

62. Outdoor CFLs

63. More efficient and lower cost refrigerators, freezers, dryers

64. Power vents

65. More efficient computers

66. Dryer that uses vacuum to dry clothes (heatless)

67. Gas tank-type water heater

68. Heating/cooling/ventilation/humidity master controlling

69. Use of automatic sensors in bathrooms, sinks, toilets for home

70. Air make-up systems for new "tight" homes

71. Better air exchange systems

72. Solar heat as another source of heat along with current system

73. Adjustable awnings

74. Easy ways to perform energy audits

75. Easier blower door assembly

76. Training on proper installation of products

77. Inspection guidelines

78. Contractor QA/QC procedures

79. Heat loss video

80. DVD's of installation

81. Incentive programs for improved practices

82. A national energy day

83. Public school energy class/day

84. Owner's manual and maintenance guide

85. Public service announcements

86. Low-interest rates for energy efficiency

87. Holistic approaches to systems interaction

88. Virtual office to eliminate commuting to office

89. Smaller houses, closer together (or attached)

\section{3- = Needed to a small extent in marketplace}


1. Easier way to seal than Aeroseal (foam at joint)

2. Sealing attics and basement crawlspace

3. Rigid fiberglass boards "doesn't burn" and rockwool

4. Basement wall insulation (exterior) that can withstand backfilling and freeze/thaw without damage that can withstand backfilling and freeze/thaw without damage

5. New construction window framing - Snap in low-e replacement window

6. Improved sealants, window sealants

7. Roof cool technologies - reflects when hot and absorbs when cold

8. Vapor barriers - intelligent ones - spray-in - for crawlspace

9. Joint compound permeability

10. Knob and tube insulating (isolating) material, easy-to-install (sonatube)

11. Improved attic access, pull-down stairway

12. Drill bits for wall retrofit (carbide and self-feed)

13. Best practices for insulating attic hatches

14. Concrete products, fasteners self-sealing

15. Finger-jointed studs (hard to find)

16. Raise gas boiler's efficiency

17. Fossil fuel free HVAC equip

18. Better stacks for wood stoves

19. Low-voltage fans $\rightarrow$ air movement

20. Bath and kitchen vent systems

21. "Smart vents" for crawl spaces (controlled by humidistat)

22. Energy recapture of exhausted air i.e. dryers, vent fans, water heaters

23. Intermittent ignition and automatic vents for converted gas lag sets

24. Cross current counter flow condensers and coils

25. Indoor evaporator Coils viewable from outside

26. Water-absorbent ground for heat pumps

27. Ways to seal duct work and nonexistent and inaccessible

28. Flex ducts - durability and less air resistance/high R-value

29. Aesthetic indoor ducts

30. Plug-in CFLs and lighting fixtures designated for CFLs. Need more of these in the market

31. LED lighting

32. Lighting controls and less expensive pin-based CFL - higher quality

33. Hi-temp CFL downlight lamps

34. Lighting: fluorescents not dimmable - lower starting temperature

35. Residential daylighting control - smart light natural light harvesting

36. Large appliances $\sim$ large users of energy - have a standard based on types and sizes so it is known that not all ENERGY STAR appliances are the same

37. Swimming pool motor efficiency

38. Well pumps efficiency

39. Easy way to turn off stand-by power consumption of electronic products - HDTV, PC, etc.

40. Energy-efficient garbage disposals

41. More efficient electric and gas ranges

42. More efficient microwaves

43. More efficient entertainment systems

44. More efficient water heaters

45. ENERGY STAR water heaters (closed combustion)

46. Better and more affordable instantaneous hot water heaters

47. Tankless water heater with 'save' mode

48. Integrated micro tank for short draws on a tankless water heater

49. High COP heat pump water heater

50. Control for furnace/ventilator interface

51. RFID tags on building products and systems for later data access

52. Motion detector that incorporates a heat sensor (occupancy sensor)

53. Tool that uses weather forecast with home energy products and technologies

54. BIPV

55. Roof-integrated solar water heater

56. Aesthetically acceptable solar collectors

57. Mainstream low-voltage lighting and appliance power by PVs

58. PV in the window glass

59. Solar shingles 
60. Something that would eliminate the power company altogether which is also cost-effective

61. Affordable IR camera

62. Notepad wireless assessment sheet - universal handheld device to facilitate assessments

63. Delta $Q$ - blower door for ducts

64. Inexpensive blower door that comes with a small portable generator and instructions

65. Low-cost inspection devices

66. Database of forms that we can quickly copy and not have to start from scratch

67. Standardized energy assessment tool/procedure

68. Wireless cell phone-notepad for energy audits and other field applications GIS, PC, IR camera, AutoCAD for client home

69. Thermal by-pass checklist is good

70. Fiber-optic inspection scope

71. Smoke sticks that last longer, do not corrode, and cost less

72. Inexpensive hand-held, fish-eye solar path finder

73. Software to calculate savings for improvements and ROI

74. CAD design for projects - design software with built in energy analysis

75. Operations training for occupant

76. Occupants behavior modification tools and child education tool integrated or linked to appliances

77. Train contractors to be better business people

78. Coordination between the trades: electrician, plumber, framer, HVAC, etc.

79. Education on in-floor heating

80. Case study database (results of previous jobs)

81. Develop a better broom so people would stop buying leaf blowers

82. Construction process e.g. too many trips to jobsite

83. Hydrogen-driven barbecue grill

84. Oversize wires by one gauge to reduce resistance losses

85. Indirect evaporative cooling combined with $\mathrm{CAC}$ and ventilation

\section{$3=$ Needed in market place}

1. Retrofit of existing attic which could or would allow the attic to be conditioned economically

2. Plywood for walls or possibly roofing that has a outside layer of insulation foam. That might help reach the new energy codes without increasing the thickness

3. Research increasing R-value in insulation without increasing the thickness

4. Smart HVAC/air handlers - read flow and Ti/To output running efficiency

5. Heat capturing driveway, ERD energy recovery driveway (parking lots) to recover heat from sun

6. Residential desiccants to make CAC more efficient with latent heat

7. Capturing and moving thermal loads within conditioned space to optimize performance

8. Easy way to turn off stand-by power consumption of electronic products - HDTV, PC, etc.

9. Simple passive solar, thermal storage, i.e. crystallite water window

10. Hybrid technology integrating water heating, refrigeration, and maybe space heating too

11. Raise the R-value on windows (R-10)

12. Inexpensive closed cell and open cell foam spraying

13. Insulation with higher R-value per inch

14. Turn a window into a wall using insulating pellets

15. Roof materials with a R-value

16. Insulating roofing felt

17. Improved radiant barriers/reflective materials

18. Smart drywall "R-wall" with vapor seal

19. HVAC and humidity control

20. HVAC systems without ducts and with concealed indoor equipment

21. Integrated $A C$ and dehumidifier that is ENERGY STAR $®$

22. Efficient one-ton ducted central AC system

23. Smart furnace to identify problems

24. Advanced evaporative cooling

25. Recycle heat and cooling within house to optimize

26. Nano-technology duct systems

27. Automatic air sealing ducts - self-sealing ducts

28. Better insulation for ducts

29. Insulted hot-water distribution systems

30. Insulated hot-water piping

31. Integrated appliances 
32. Water heater integrated with refrigerator

33. Built-in efficiency feedback systems - self-correcting systems

34. Pre-fabricated passive solar components

\section{$3+=$ Needed to a large extent in market place}

1. Easy seal for unsealed can light

2. Self-sealing building components

3. A product to cover can lights for prevention of heat loss

4. Synthetic studs with R-value

5. Non-leaky cabinets (mechanical)

6. Alternative to flex duct - Miracle flex duct

7. Easy-to-install leakless duct systems

8. Duct systems need to be re-engineered, need to include proper flow, better registers and seals built into system

9. Home energy automation devices leading to fully programmable buildings focused on efficiency to monitors $\mathrm{ACH}$ with error codes etc.

10. Heat loss monitor, energy use monitor

11. Monitoring - need to do more of it $\rightarrow$ education

12. Quick analysis, better tracking

13. Thermostat or panel box that shows consumption in dollars

14. Special electric meter for high use item, i.e. AC unit

15. Pay-as-you-go utility billing

16. Advanced electric metering as power is used - show consumption in dollars at unit level

17. Real-time monitoring of end use/whole house

18. TOU rate meters (customer interfaces)

19. Control for furnace/ventilator interface

20. Thermostats - point of lots of useful information - smart, interactive, intuitive, adaptive, when to change filter and where

21. Appliance power meter built in

22. Built-in appliance usage monitoring, event detection - data loggers tied to the Internet

23. Thermostats/controls/point-of-use information

24. Controls for HVAC (RFID)

25. AC refrigerant charging level indicator (whistle)

26. Instantaneous feedback to monitor and change load

27. More efficient dehumidifiers

28. New homes sold with operating manuals that are focus on energy efficiency - the market may be ready for this

\section{4 = Classification unknown or feedback unclear}

1. Attic expanding air mattress with radiant barrier, moisture barrier, Aerogel

2. Cardboard vent baffle for radiant barrier- foil radiant barrier on attic side

3. Shingles that have an interconnecting system for energy transmission

4. Heat pumps for manufactured homes (current spec does not match with HUD)

5. Economical integrated air sealing mechanical ventilation package as one product

6. Conventional water heater to instantaneous, combo-H, solar, tank efficiency

7. Flow meter for insulation blowing machines to measure volume/density

8. In a stand alone PV system, the batteries are often fully charged by noon. If there were a way to shunt that potential energy afternoon to heat the domestic hot water that would increase the efficiency of the system

9. Device that quickly and efficiently gives you existing R-values of walls, windows, etc.

10. Database of all attic and wall insulation levels in existing homes (aerial IR image database)

11. Understanding building interactions by non-energy trades (roof, paint, siding)

12. Understanding building interactions by non-energy trades (roof, paint, siding)

13. 3" to 5" MERV11 air filters/return air registers integrated 


\section{$5=$ Not applicable to existing housing or DOE cannot perform associated research}

1. Unvented fireplaces- fail-safe chimney - top dampers for gas fireplaces

2. Zero-point energy, nuclear energy, hydrogen, solar act for off grid lighting and cleaner cheaper power plants

3. A checklist of items related to the actual building process that you could look at during the design process

4. Required trade and zone specific schools for builders, for specialty - best practices sheet stapled on site

5. NFRC consumer product directory, CPD (gamma and ARI) simplified

6. Training on mold risks, airborne, prevention, remodeler protection

7. Database of retail sources of product: you can get this package, costing that much, in stock at this retailer, saving dollars until Tuesday

8. Quick alert or public info on $\mathrm{CO}$ danger of running generators in attached garages

9. Access to best available architectural drawings of existing home from tax office/government agency

10. Equal subsidies for conservation/efficiency products and programs as supply-side

11. More forgiving siding

12. Cladding systems - need integral drainage planes

13. Maintenance-free HVAC system design

14. Disposable furnace/AC coil

15. Fail-safe chimney top damper for gas fireplaces

16. Uniform appearance of outdoor AC units

17. Mastic that is machine washable?

18. Make tax credit for on-demand water heater

19. For high-rise multifamily building energy management control

20. Air quality monitor integrated with HRV use

21. Studies showing effect of indoor air quality on human health

22. Solar panel installation mounts

23. Electric generation from geothermal heat pumps

24. Automatic water flow control/sensing

25. Water management in standard construction is nonexistent

26. Rain water collection devices

27. Better utilize water supply

28. Low-flush toilets that work

29. Grey water from sinks to water closet

30. Better waste water management without negative stigma

31. Energy audit of the White House

32. Indoor air quality software

33. Better energy code enforce

34. Quality of work, Construction quality inspection

35. Durability rating system (MATCS, PROC)

36. Live access to building science experts

\section{$6=$ Responsibility of other DOE program offices or federal agencies}

1. Solar electric panel which have higher output and which would be economic to install

2. Using hybrid car as a portable cogeneration unit for house and office heating cooling electricity

3. Help with marketing to consumer: Marketing for the ideas of energy conservation which will promote more awareness and demand for conservation

4. Bundle PV, solar DHW and efficiency into a package when marketing to public. "Pay no income tax next year" $\$ 4,500$ credit for this $\$ 15,000$ package which saves $50 \%$ of your energy. Discount financing available

5. Promote energy efficiency through TV, newspapers, radio, schools, coupons

6. SEOs are key to taking ideas and building them into marketable realities

7. Accessible plumbing/electrical closets for flexibility of upgrades

8. Ban unvented space heaters

9. Photovoltaic cells, PV fabrics

10. Plug and play solar hot water systems

11. Solar hot water heating systems

12. Better batteries for solar

13. Easily found and maintained solar products

14. Combo PV plus solar water heating

15. PV connected to fuel cell

16. Micro-power wind turbine and other collectors

17. KWh batteries cheap and environmentally friendly

18. Fitness equipment/kinetic energy as generators 
19. Geothermal systems

20. Access to practical fuel cells

21. Better on-site generation technologies

22. Solar/hydrogen fuel cell

23. Low-cost electric generation off geothermal heat pumps

24. Clean, affordable energy generation in the home

25. Software for active solar design

26. Code revision (e.g., on venting, etc.)

27. More advertising since energy costs are rising

28. Marketing database to direct targeted marketing

29. Campaign promoting HP/efficiency career path

30. Coop ownership of ground-source heat pumps

31. Kitchen/yard waste classification system 


\section{Appendix E: Technology and Best Practices Research for New Construction and Major Renovations}

This appendix contains preliminary Internet research on the state of commercialization of the technology and best practices suggested by residential industry stakeholders as "needed to a large extent" (i.e., feedback satisfying the " $3+$ " evaluation criteria) that were eliminated from more comprehensive evaluation for the purposes of existing homes research.

The research covers the topics listed below:

- Self-sealing building components

- Alternative studs (having a better R-value than conventional wood or steel studs).

\section{Self-Sealing Building Components}

According to industry stakeholders, DOE should research self-sealing building components. Such building components could include individual home systems such as ductwork discussed earlier all the way up to snap together houses manufactured or constructed based on a grid system.

\section{Current Technologies}

The following is a sampling of existing "self-sealing" products used in the home construction business:

- $\quad$ Self-locking, self-sealing fasteners have helped engineers and builders solve threaded component fastening problems for the last 50 years, as well as solving vibration issues. These fasteners provide airtight, leakproof seal against liquids, air and other gases, and can be removed from equipment and reused without spoiling sealing action.

- Single-component, self-sealing mastics have helped prevent moisture from penetrating nonmoving joints in concrete construction.

- Weatherstripping, by its nature, is typically considered self-sealing.

- Tube pipe insulation is an easy, effective way to block heat loss or gain to save energy. This insulation can be used on either hot or cold water pipes. The insulation stops condensation on cold water pipes to prevent water damage. Installs easily using pre-cut, self-sealing slits.

- Flashing systems offer home moisture protection around roofs, windows, and doors. Studies show that inadequate design and construction of flashings are responsible for a high percentage of window and door leaks. Poor design detail is one of the most common causes of building envelope defects and builder callbacks. When installed properly, flashing can intercept and direct the flow of water to designed drainage paths to prevent water from 
penetrating the building. Advanced flashing systems have self-sealing properties that can stop leaks around fasteners that may later be driven through the adhesive.

- Most roof shingles today have self-sealing properties.

- Lego ${ }^{\circledR}-$ like, insulated concrete forms consist of hollow polystyrene foam blocks that are stacked into the shape of the exterior walls of a structure and serve as forms for poured concrete. These systems minimize the need for extra gluing, taping, or strapping of joints. Also, water dams between nubs prevent water seepage which insures proper concrete cure and reduces the possibility of moisture infiltration.

\section{New Technologies and Best Practices}

The U.S. Department of Housing and Urban Development's (HUD) Partnership for Advancing Technology in Housing (PATH) has been researching and promoting homes of the future that essentially are designed using a grid system (e.g., in 3-inch increments) so building components can be snapped together. Some building components are already using incremental dimensioning, including door and cabinet manufacturers. The Massachusetts Institute of Technology (MIT) House $n$ project has begun research in this area from a "whole-house" perspective. However, Bensonwood Homes is likely the only firm in the United States who has adopted these principles in practice. Bensonwood, for example, has 600 staircase designs that can be cut-and-pasted into any of their grid-based home designs.

\section{Conclusion}

The products mentioned above are just a small part of what is available on the market, but most of these products center around only a few building component types (shingles, fasteners, weatherstripping, etc.). However, for the most part, there has been very little done by industry to move towards the snap-together, self-sealing house. DOE could focus a portion of its RD\&D resources towards standardized (grid-based) building components and selected self-sealing, individual building systems (such as ductwork, wall, electrical, and plumbing systems.)

\section{Alternative, Energy-Efficient Studs}

Industry stakeholders suggest that DOE research alternative or synthetic energy-efficient studs. Current solid wood and steel studs do not provide much insulating value, and there is very little research being performed in the industry to develop a more efficient alternative.

\section{New Technologies and Current Best Practices}

Four years ago, Philadelphia architect LeRoy Landers developed a new steel stud design that costs about the same as a standard steel stud, yet significantly lowers heat loss. Instead of lying flat against the sheathing and interior finish, the stud's edges are formed into ridges that leave the middle recessed. Since only the narrow ridges touch the wall, thermal conduction is greatly 
reduced. Although still not as thermally efficient as wood framing, Landers' stud is a significant improvement over typical steel studs. Studies done at Oak Ridge National Laboratory (ORNL) showed that Landers' studs significantly reduced the temperature differences across the interior surface of the wall. Two variations of the stud were tested. A stud with a 1/4-in. recess improved the wall's overall R-value by nine percent over standard steel studs; a stud with a $1 / 2$-inch recess raised it by 16 percent.

Other innovations include changing the way walls are constructed entirely, for example, using structurally insulated panels (SIPS). SIPS have been researched and promoted by DOE for some time now and are beginning to resonate in the marketplace. Another example of a new wall product is Grid-PLANK ${ }^{\mathrm{TM}}$ by Amazon Forms One, Inc., which is a lightweight, solid tilt wall which utilizes metal stud technology for support and Grid-MIX ${ }^{\mathrm{TM}}$, which fills the voids between the metal framing. Grid-MIX is comprised of 85 percent recycled polystyrene giving the wall system the necessary insulation factor combined with the strength and durability of concrete. The manufacturer claims an energy savings up to $50 \%$ over conventional wall systems.

Buildings using metal framing technology are time consuming and labor intensive, so Amazon Forms One developed a computerized process to fabricate metal walls rapidly at the factory. After the metal walls are custom assembled, Grid-Mix a mixture of recycled polystyrene and Portland cement, is added to the voids in the wall panel. Polystyrene is the insulator used to fill the voids in the metal walls. The unique wall system is fire resistant, termite resistant, black mold resistant, will not rot, and makes the home acoustically and environmentally friendly.

Grid-PLANK ${ }^{\mathrm{TM}}$ is in the process of being tested. According to Pocket Ref by Thomas J. Glover, cut cell polystyrene has an R-value of 4 per inch. Since Grid-PLANK ${ }^{\mathrm{TM}}$ is $3 \frac{5}{8}$ inches thick and made of $85 \%$ recycled polystyrene, one could conclude the R-value to be approximately 12 . Coating the exterior wall with mortar has a very low R-value, reduced air infiltration and thermal mass combined, contributes greatly to improving the overall energy value of the wall above the $\mathrm{R}-12$ value.

Besides new and innovative technologies, the way walls are constructed has also been researched by DOE and used in the field to increase a wall's thermal resistance. For example, walls are constructed using $2 \times 6$ instead of $2 \times 4$ studs or the $2 \times 4$ studs are staggered along $2 \times 6$ sole and top plates, where no board touches both the interior and exterior wall surfaces.

Bensonwood Homes has perfected what they call the Open-Built ${ }^{\circledR}$ system using timber framing and innovative I-studs. The Open-Built ${ }^{\circledR}$ walls are a significant evolution of typical panelized, stress-skin and foam core panels used by most timber frame companies. Fabrication of large wall sections and carefully detailed joint solutions provide an air-tight enclosure, and detailing and pre-applying of gaskets ensure a tight building envelope and, therefore, high thermal performance. Another advantage in the foam insulated wall is the addition of their unique OpenBuilt I-flange stud, which provides anchor points for exterior siding and interior fixtures while minimizing thermal losses. 
Appendix E: Technology and Best Practices Research

\section{Conclusion}

As described above, DOE has researched several new factory-built, panelized wall systems and improved ways to construct site-built walls. However, more research and development need to be performed on products that can replace today's inefficient wood and steel studs, while remaining essentially the same dimensions. 


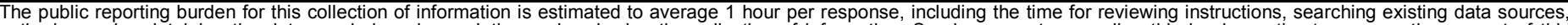

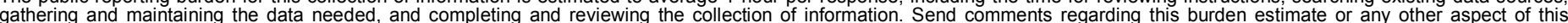

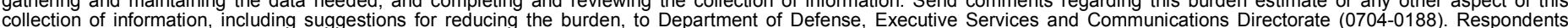

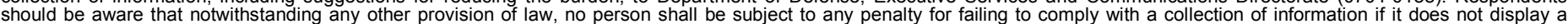

should be aware that notwithstanding

PLEASE DO NOT RETURN YOUR FORM TO THE ABOVE ORGANIZATION.

\begin{tabular}{l|l|l|l} 
1. REPORT DATE $(D D-M M-Y Y Y Y)$ & 2. REPORT TYPE & 3. DATES COVERED (FrOm - TO)
\end{tabular}

June 2007

Technical Report

4. TITLE AND SUBTITLE

Industry Stakeholder Recommendations for DOE's RD\&D for

Increasing Energy Efficiency in Existing Homes

5a. CONTRACT NUMBER

DE-AC36-99-G010337

5b. GRANT NUMBER

5c. PROGRAM ELEMENT NUMBER

6. AUTHOR(S)

Patricia Plympton and Leila Dagher, NREL

Bill Zwack, SENTECH, Inc.

5d. PROJECT NUMBER

NREL/TP-710-41705

5e. TASK NUMBER

BEES.0750

5f. WORK UNIT NUMBER
7. PERFORMING ORGANIZATION NAME(S) AND ADDRESS(ES)

National Renewable Energy Laboratory

1617 Cole Blvd.

Golden, CO 80401-3393
8. PERFORMING ORGANIZATION REPORT NUMBER

NREL/TP-710-41705

9. SPONSORING/MONITORING AGENCY NAME(S) AND ADDRESS(ES)

10. SPONSOR/MONITOR'S ACRONYM(S) NREL

11. SPONSORING/MONITORING AGENCY REPORT NUMBER

12. DISTRIBUTION AVAILABILITY STATEMENT

National Technical Information Service

U.S. Department of Commerce

5285 Port Royal Road

Springfield, VA 22161

13. SUPPLEMENTARY NOTES

14. ABSTRACT (Maximum 200 Words)

This technical report documents feedback obtained by NREL from building practitioners on the direction of future U.S. Department of Energy (DOE) research and development in the area of improving energy use in existing residential buildings. The Building Technology Program within DOE specifically sought feedback from stakeholders on which technologies and best practices the program should pursue.

15. SUBJECT TERMS

Stakeholders; DOE research direction; energy efficiency; existing homes

\begin{tabular}{l}
\hline \begin{tabular}{l|l|l|}
\hline 16. SECURITY CLASSIFICATION OF: \\
\hline $\begin{array}{l}\text { a. REPORT } \\
\text { Unclassified }\end{array}$ & $\begin{array}{c}\text { b. ABSTRACT } \\
\text { Unclassified }\end{array}$ & $\begin{array}{l}\text { c. THIS PAGE } \\
\text { Unclassified }\end{array}$ \\
& & \\
\hline
\end{tabular}
\end{tabular}

\begin{tabular}{|c|c|} 
17. LIMITATION \\
OF ABSTRACT \\
UL
\end{tabular}

19a. NAME OF RESPONSIBLE PERSON

19b. TELEPHONE NUMBER (Include area code) 